\title{
Meeting places and social capital supporting rural landscape stewardship: A Pan-European horizon scanning
}

\author{
$\underline{\text { Per Angelstam }}^{1}$, Mariia Fedoriak $^{2}, \underline{\text { Fatima Cruz }}^{3}, \underline{\text { José Muñoz-Rojas }}^{4}, \underline{\text { Taras Yamelynets }}^{5}, \underline{\text { Michael Manton }}^{6}{ }^{11} \underline{\text { Carla-Leanne }}^{\text {Mobert }}$ \\ $\underline{\text { Washbourne }}^{7}$, Denis Dobrynin $^{8}, \underline{\text { Zita Izakovičova }}^{9}$, Nicklas Jansson $^{10}, \underline{\text { Bogdan Jaroszewicz }}^{11}, \underline{\text { Robert Kanka }}^{9}, \underline{\text { Marika Kavtarishvili }}^{12}$, \\ Leena Kopperoinen $^{13}{ }^{13}$ Marius Lazdinis ${ }^{14}$, Marc J. Metzger ${ }^{15}$, Deniz Özüt ${ }^{16}$, Dori Pavloska Gjorgjieska ${ }^{17}$, Frans J. Sijtsma ${ }^{18}$, Nataliva \\ $\underline{\text { Strvamets }}^{19,20}, \underline{\text { Ahmet Tolunav }}^{21}, \underline{\text { Turkay Turkoglu }}^{22}$ Bert van der Moolen $^{23}$, Asiva Zagidullina $^{24}$ and Alina Zhuk $^{25}$
}

ABSTRACT. Achieving sustainable development as an inclusive societal process in rural landscapes, and sustainability in terms of functional green infrastructures for biodiversity conservation and ecosystem services, are wicked challenges. Competing claims from various sectors call for evidence-based adaptive collaborative governance. Leveraging such approaches requires maintenance of several forms of social interactions and capitals. Focusing on Pan-European regions with different environmental histories and cultures, we estimate the state and trends of two groups of factors underpinning rural landscape stewardship, namely, (1) traditional rural landscape and novel face-to-face as well as virtual fora for social interaction, and (2) bonding, bridging, and linking forms of social capital. We applied horizon scanning to 16 local landscapes located in 18 countries, representing Pan-European social-ecological and cultural gradients. The resulting narratives, and rapid appraisal knowledge, were used to estimate portfolios of different fora for social interactions and forms of social capital supporting landscape stewardship. The portfolios of fora for social interactions were linked to societal cultures across the European continent: "self-expression and secular-rational values" in the northwest, "Catholic" in the south, and "survival and traditional authority values" in the East. This was explained by the role of traditional secular and religious local meeting places. Virtual internet-based fora were most widespread. Bonding social capitals were the strongest across the case study landscapes, and linking social capitals were the weakest. This applied to all three groups of fora. Pan-European social-ecological contexts can be divided into distinct clusters with respect to the portfolios of different fora supporting landscape stewardship, which draw mostly on bonding and bridging forms of social capital. This emphasizes the need for regionally and culturally adapted approaches to landscape stewardship, which are underpinned by evidence-based knowledge about how to sustain green infrastructures based on both forest naturalness and cultural landscape values. Sharing knowledge from comparative studies can strengthen linking social capital.

Key Words: green infrastructure; human well-being; landscape approach; regional studies; rural development; social-ecological system

\section{INTRODUCTION}

Natural capital is widely acknowledged as a key foundation for human well-being. The frameworks of "ecosystem services" (e.g., Costanza and Daly 1992, MEA 2005, Braat and de Groot 2012), "landscape services" (Termorshuizen and Opdam 2009), "connecting nature and people" (Díaz et al. 2015, Pascual et al. 2017), and "nature's contribution to people" of the Intergovernmental Science-Policy Platform on Biodiversity and Ecosystem Services (IPBES 2019), were all developed to improve inclusion of natural capital into political and economic decision making across governance levels (Angelstam et al. 2019a). These frameworks aim at facilitating integration of stakeholders and knowledge systems. However, in spite of the proliferation of such frameworks the degradation of natural capital continues at both global (IPBES 2019) and regional levels (e.g., Acha and Newing 2015, Angelstam et al. 2018, Naumov et al. 2018). Additionally, fragmented policy, governance, and land ownership hinder integrated and strategic spatial planning of different land covers aiming at landscape sustainability (e.g., Selman 2012, Lazdinis et al. 2019). Because of their inherent complexity, these socialecological system challenges can often be viewed as wicked (Duckett et al. 2016). Steering toward sustainable landscape stewardship as "a place-based, landscape-scale expression of broader ecosystem stewardship" (Bieling and Plieninger 2017:5,

\footnotetext{
${ }^{1}$ School for Forest Management, Swedish University of Agricultural Sciences, Skinnskatteberg, Sweden, ${ }^{2}$ Department of Ecology and Biomonitoring, Yuriy Fedkovych Chernivtsi National University, Chernivtsi, Ukraine, ${ }^{3}$ Department of Psychology, Sustainable Forest Management Research Institute, University of Valladolid, Campus de la Yutera, Palencia, Spain, ${ }^{4}$ MED-Mediterranean Institute for Agriculture, Food and the Environment, Universidade de Évora, Núcleo da Mitra Gab. 206, Évora, Portugal, ${ }^{5}$ Faculty of Geography, Ivan Franko National University, Lviv, Ukraine, ${ }^{6}$ Faculty of Forest Science and Ecology, Vytautas Magnus University, Kaunas district, Lithuania, ${ }^{7}$ Department of Science, Technology, Engineering and Public Policy, University College London, London, United Kingdom, ${ }^{8}$ Department of Geographical and Historical Studies, University of Eastern Finland, ${ }^{9}$ Institute of Landscape Ecology, Slovak Academy of Sciences, Bratislava, Slovakia, ${ }^{10}$ IFM Biology, Conservation Ecology Group, Linköping University, Linköping, Sweden, ${ }^{11}$ Białowieża Geobotanical Station, Faculty of Biology, University of Warsaw, Białowieża, Poland, ${ }^{12}$ LL.M European and International Law School, Tbilisi, Georgia, ${ }^{13}$ Biodiversity Centre, Finnish Environment Institute SYKE, Helsinki, Finland, ${ }^{14}$ Directorate-General for Agriculture and Rural Development, European Commission, Brussels, Belgium, ${ }^{15}$ The University of Edinburgh, GeoSciences, Edinburgh, UK, ${ }^{16}$ Nature Conservation Centre, Ankara, Turkey, ${ }^{17}$ Head Office/Secretariat of the Regional Rural Development Standing Working Group (SWG) in SEE, Skopje, North Macedonia, ${ }^{18}$ Faculty of Spatial Sciences, University of Groningen, Groningen, The Netherlands, ${ }^{19}$ Nature reserve "Roztochya", Ivano-Frankove, Ukraine, ${ }^{20} \mathrm{Ca}$ ' Foscari University of Venice, Mestre, Italy, ${ }^{21}$ Isparta Unıversity of Applied Sciences, Faculty of Forestry, Isparta, Turkey, ${ }^{22}$ Department of Forestry, Köycegiz Vocational School, Mugla Sitki Kocman University, Mugla, Turkey, ${ }^{23}$ Independent consultant, ${ }^{24}$ Department Ecology and Vegetation Science, Saint-Petersburg State University, SaintPetersburg, Russia, ${ }^{25}$ Department of Ecology and Biomonitoring, Chernivtsi National University, Chernivtsi, Ukraine
} 
Primdahl et al. 2018) that maintains natural capital requires knowledge and skills to navigate the complexity of interactions within landscapes' social systems through an inclusive societal learning process (e.g., Baker 2006).

However, trade-offs among costs and benefits, and the unequal distribution of different aspects of natural capital among stakeholders is challenging, particularly in the rural areas that provide material renewable and nonrenewable resources and immaterial values to often distant urban populations (e.g., Rodríguez et al. 2006, Bijker and Sijtsma 2017, Turkelboom et al. 2018). This requires collaboration among territorial actors sensu Hägerstrand (2001), and knowledge about the states and trends of ecosystem services. This calls for new modes of knowledge production and learning (e.g., Gibbons et al. 1994, Hirsh-Hadorn et al. 2008, Guimarães et al. 2018, Hilbers et al. 2019). As a consequence, social innovations are now arising, aiming at areabased collective action across multiple sectors in landscapes involving knowledge-based multilevel fora for social interactions (e.g., IMFN 2008, Angelstam et al. 2013, 2019b, Sayer et al. 2013, Singh et al. 2013). These can be considered as landscape approach innovations (Maffey et al. 2015, Arts et al.2017), and are mediated through newly constructed actor and stakeholder fora for social interaction.

Inspired by Putnam (1995, 2001), both Szreter and Woolcock (2004) and Agger and Jensen (2015) proposed a conceptual framework for applying social capital to facilitate contacts within individual social networks of stakeholders (i.e., bonding social capital), horizontally among different networks (i.e., bridging social capital), and vertically with external forms of power at different levels (i.e., linking social capital). Sustaining these three groups of relations can provide land use decision makers and spatial planners, along with members of civil society, with necessary access to resources, ideas, and information toward landscape stewardship strategies and options that sustain functional green infrastructure, i.e., "a strategically planned network of high quality natural and semi-natural areas with other environmental features, which is designed and managed to deliver a wide range of ecosystem services and protect biodiversity in both rural and urban settings" (European Commission 2013:3).

Collective actions aiming at sustainability have a long history in rural Pan-European landscapes (e.g., Erixon 1960). Today these collective actions take place in a "glocalized" world, where every rural area is more strongly than ever before part of, and affected by, a large national, international, or global network of economic and social-cultural activities. This has modified rural landscape collective actions (e.g., Sporrong 1998). In some regions traditional collective actions have disappeared, in some they have changed, and in others they remained unchanged. Thus, traditional collective actions still occur on the European continent in some economically peripheral regions that also have retained traditional forms for land use (e.g., Angelstam et al. 2003, Barnaud et al. 2018). This provides a unique opportunity to both EU and non-EU countries as a "time machine" (Angelstam et al. 2011) for in-depth comparisons of regions in different stages of rural landscape transition, including approaches to landscape stewardship (e.g., Angelstam et al. 2013). The European continent hosts a particularly steep gradient in cultural values (Inglehart 2018, Welzl 2013), and legacies of multilevel vs. top-down societal and policy steering across rural regions (Van Eupen et al. 2012). To capture this, Huntington (1997) employed the term "cultural fault lines." This Pan-European diversity of social-ecological contexts demonstrates not only challenges affecting this across rural landscapes, but is also a key resource for knowledge production and learning toward sustainable rural landscapes (Angelstam et al. 2019b).

The aim of this study is to explore, in a suite of place-based case studies, two factors that can underpin landscape stewardship toward functional green infrastructure. The first is fora for social interactions, including traditional and novel face-to-face, as well as virtual ones. The second is the portfolio of bonding, bridging and linking forms of social capital. Empirical data about states and trends were collected through rapid rural appraisal (sensu Chambers 1981, 1994) in 16 rural landscapes located in 18 countries on the European continent with different environmental histories in terms of biophysical, anthropogenic, and cultural legacies (e.g., Worster 2005, Inglehart 2018).

\section{THEORETICAL FRAMEWORK}

\section{Traditional, novel, and virtual fora for social interactions}

We focus on three types of social interactions affecting the opportunity for landscape stewardship. Traditional fora for collective action facilitate the maintenance of rural cultures, and provide places for interactions within and among land use sectors (e.g., Sporrong 1998). Novel fora focusing on local and regional interactions across sectors emerged in the wake of sustainable development in the 1980s (e.g., IMFN 2008). Finally, virtual fora appeared as social web-based interactions across sectors, which accelerated with the emergence of smartphones in the 2010s (Salemink et al. 2017, Thulin et al. 2020). This involves two shifts. The first is from local village to region and from traditional land use sectors, e.g., forestry and agriculture, to multiple sectors, e.g., cultural heritage, tourism, and energy. The second shift was from physical interactions to include also virtual interactions. These temporal shifts are complicated by the spatial expansion of these shifts. Whereas the first shift is linked to frontiers of landscape changes in social-ecological systems across Europe (Inglehart 2018), the second emerged rapidly at the global level.

\section{Traditional fora}

For long time the village was the main social-ecological unit in rural Europe (Hartel and Plieninger 2014). Villages were defined by traditional land use zones, such as the ancient Roman "domushortus-ager-saltus-silva" ("house-garden-field-meadow-pasture"; e.g., Elbakidze and Angelstam 2007), and held inclusive governance arrangements securing self-subsistence (e.g., Erixon 1960). Traditional village systems sustained the production of multiple ecosystem services derived from agriculture and animal husbandry, as well as wood and nonwood forest goods (e.g., Garrido et al. 2017, Stryamets et al. 2020), and contributed to cultural and social capitals (Agnoletti 2006). However, along with the gradual expansion of the industrial revolution in most of Europe, traditional village systems were modified from the 18th century by reorganizing land tenure top-down from communal units to individual landowners aimed at increasing the production of food, feed, wood, fuel, and fiber (e.g., Myrdal and Morell 2011). Simultaneously, this led to declining social capital (Erixon 1946), but also to deterioration of both traditional cultural landscapes 
and naturally dynamic forests. Urbanization phases then developed across Europe. Major cities were affected first, but gradually urbanization processes affected traditions in rural areas (Antrop 2004).

\section{Novel fora}

Policies about rural development (OECD 2017), green infrastructure (European Commission 2013) and forests (Forest Europe 2015), as well as the EU Water Framework Directive from 2000, the European Landscape Convention from 1999, and European Framework for Action on Cultural Heritage from 2019 have triggered the need for and appearance of social innovations aiming at collective action in landscapes involving knowledgebased collaboration across multiple sectors and governance levels. Such place-based integration of knowledge production and learning among actors and stakeholders toward sustainable landscapes has become generically termed landscape approach (e.g., Angelstam et al. 2013, Sayer et al. 2013, Singh et al. 2013, Arts et al. 2017). To enhance regionally adapted implementation of policies aimed at sustainable development and sustainability in landscapes as local social-ecological systems (Matthews and Selman 2006), a wide range of novel landscape approach concepts have emerged, namely, model forest, biosphere reserve, ecological networks such as the European Green Belt, ecomuseum, and longterm social-ecological research (LTSER) platform (e.g., Romaniuk et al. 2001, Angelstam et al. 2019a, $b$ ).

\section{Virtual fora}

At the end of the 20th century, social interactions in real time became extended beyond physical places through the Internet. Networks and communities therefore now exist in both physical places such as neighborhoods, and in cyberplaces (Wellman 2001, Driskell and Lyon 2002). Moreover, community was seen as being physically lost from or reduced in its original environment, the local place, typically a village, a community gathering place, or a residential neighborhood because of rural depopulation and increased global mobility (Lasanta et al. 2017). This encouraged the idea that community could be re-gained in the facilitated environment of shared space, typically through voluntary associations or working groups. Today the digital environment of cyberspace is rapidly becoming the most important forum for regaining community (Driskell and Lyon 2002). Nowadays various types of communities can be maintained by means of multiple Internet applications and platforms, for the exchange of information, keeping up the old and building new social networks, self-promotion, learning, and playing. At times these are used with the aims of supporting nature conservation and landscape governance (Daams and Sijtsma 2013, Bijker et al. 2014, Arts et al. 2015, Maffey et al. 2015, Bubalo et al. 2019).

\section{Bonding, bridging, and linking forms of social capital}

To succeed with place-based landscape approaches, it is crucial to facilitate landscape stewardship across power differentials at different levels of governance (Bijker and Sijtsma 2017). This applies in particular to actors, stakeholders, and organizations responsible for delivering continuous face-to-face interactions. The effectiveness of traditional, novel, and virtual fora depend on the constituent level and types of social capital (e.g., Ferragina 2012). The term social capital captures the idea that social bonds are critical for sustainability (Pretty 2003). Social capital is a property of a group or a network of social system actors (Adler and Kwon 2002). It defines how these social actors are placed in relation with other individual people and societal groups. Social capital is related with social dynamics and power, which builds on social interactions in a specific cultural context (Schafft and Brown 2010). Human well-being outcomes can be improved by expanding the quality and quantity of bonding social capital (among friends, family, and neighbors, networks, interest groups) and bridging social capital (trusting relations between those from different other sectorial, demographic, and spatial groups), and linking social capital, which introduces a conceptual and empirical distinction as it pertains to individuals' overall vertical portfolio of social relationships (Szreter and Woolcock 2004; Fig. $1)$.

Fig. 1. Illustration of the interactions within a group of people in an area (bonding social capital), horizontally among groups (bridging social capital), and vertically (linking social capital).

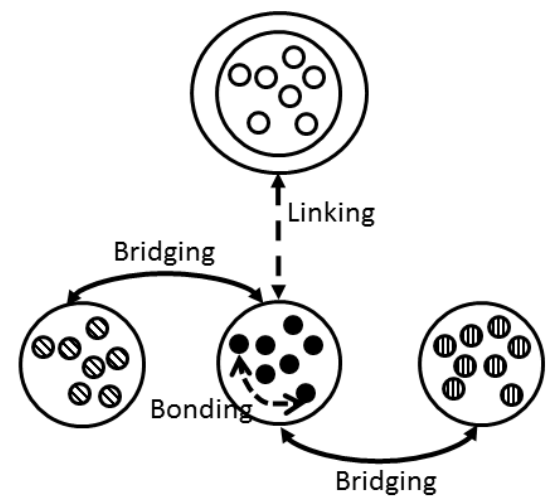

Local actors

Local groups

Powerful institutions

\section{METHODS}

\section{Case study regions and hotspot landscapes}

To address the challenge of landscape stewardship supporting the maintenance of representative green infrastructures in Europe, we applied an approach based on multiple landscapes as case studies (e.g., Elands and Wiersum 2001, Angelstam et al. 2013). As suggested by Inglehart (2018), rather than limiting the choice of landscape case studies to countries with strong research traditions such as within the European Union, we advocate choosing sampling units that cover a wide range of variation in social-ecological systems by including the entire European continent, thus covering a wide range of social-ecological contexts. To mirror the Pan-European variation in environmental history and legacies of societal steering, we selected 16 case study regions that represent two gradients on the European continent. The first is biophysical between intact forest landscapes with highly functional green infrastructures for biodiversity, and landscapes that have been increasingly modified by historic forest alteration and fragmentation (Fig. 2). The second gradient reflects cross-cultural variation (Inglehart 2018, Welzl 2013), and governance arrangements among both EU and non-EU countries (Fig. 3). The size of the selected case study regions (order of magnitude $10^{4}$ to $10^{5} \mathrm{~km}^{2}$ ) matches recommendations for (1) social-ecological system research (Mirtl et al. 2008), (2) functional 
Fig. 2. Map showing the location of 16 case study regions representing the gradient in historic forest fragmentation from intact forest landscapes (Potapov et al. 2017) via other still contiguous (> 50\% forest cover), somewhat fragmented (50-20\% forest cover), to severely fragmented forest landscapes $(<20 \%$ forest cover). See Table 1 for description of each case study region and constituent hotspot.

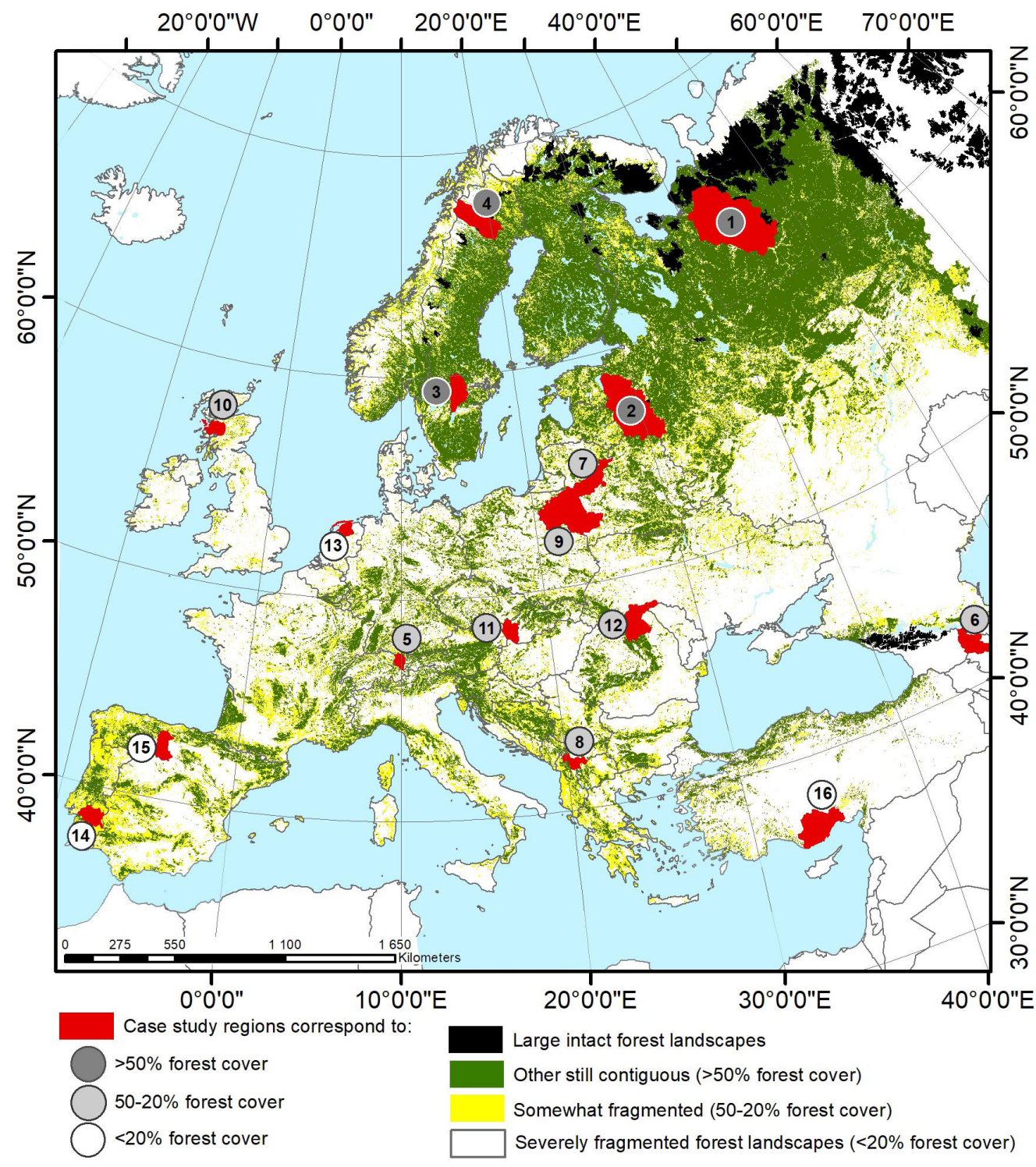

green infrastructure for biodiversity indicated by focal species' local population area requirements (Angelstam et al. 2004), and (3) commuting to job and economic activity (see Angelstam et al. $2019 b$ ). The median size of the case study regions was $5300 \mathrm{~km}^{2}$ (Table 1).

Within each of the case study regions, we selected a local "hotspot" landscape (see Table 1). The choice aimed at reflecting barriers and bridges for the maintenance of green infrastructure representing both visions of naturalness (e.g., Winter 2012) in areas with higher forest cover, and cultural landscapes in areas where natural potential forest vegetation is lower (Agnoletti 2006). Our sample of "hotspot" landscapes represented not only large variation in biophysical and environmental history factors related to latitude and altitude and forest cover as a proxy of human footprint on green infrastructure (Fig. 4), but also factors affecting social capital such as legacies of stewardship and societal steering (see Appendix 1). The median size of the hotspot landscapes was $700 \mathrm{~km}^{2}$ (Table 1). In a parallel study, we focused on biophysical and biocultural aspects of the case study regions and hotspot landscapes (Angelstam et al. 2021).

\section{Horizon scanning}

Horizon scanning is the formal process of gathering, processing, and disseminating information to support more effective decision making for the future (e.g., Shackleton et al. 2017). Various 
Table 1. List of case study regions and constituent local "hotspot" landscapes chosen on the European continent.

\begin{tabular}{|c|c|c|c|c|c|}
\hline Country & $\begin{array}{l}\text { ID in } \\
\text { Fig. } 2\end{array}$ & Case study region & Size of region $\left(\mathrm{km}^{2}\right)$ & Local hotspot landscape & $\begin{array}{r}\text { Size of } \\
\text { hotspot } \\
\left(\mathrm{km}^{2}\right)\end{array}$ \\
\hline \multicolumn{6}{|l|}{$50 \%$ forest cover; Figure 4} \\
\hline Russia (N) & 1 & $\begin{array}{l}\text { Pinega river basin plus buffer in five } \\
\text { Arkhangelsk districts }\end{array}$ & 92,232 & Dvina-Pinega forest massif & 9129 \\
\hline Russia (W) & 2 & Pskov oblast & 55,300 & Strugi Krasnye district & 3090 \\
\hline Sweden (S) & 3 & $\begin{array}{l}\text { Örebro county and Karlsborg } \\
\text { municipality }\end{array}$ & $8546+797$ & $\begin{array}{l}\text { Laxå municipality with Tiveden } \\
\text { national park }\end{array}$ & 743 \\
\hline Sweden $(\mathrm{N})$ & 4 & Jokkmokk municipality & 19,344 & Kvikkjokk & 419 \\
\hline \multicolumn{6}{|l|}{$20-50 \%$ forest cover; Figure 4} \\
\hline Austria (A) & 5 & Vorarlberg & 2601 & Montafon’s 10 villages ${ }^{\star}$ & 560 \\
\hline Georgia (GE) & 6 & Kakheti region & 11,311 & $\begin{array}{l}\text { Tusheti province in Akhmeta } \\
\text { municipality }\end{array}$ & 969 \\
\hline Lithuania (LT) & 7 & Dzukija ethnographic region & 13,149 & $\begin{array}{l}\text { Dzukija National Park and Cepkeliu } \\
\text { Nature Reserve }\end{array}$ & 697 \\
\hline $\begin{array}{l}\text { North Macedonia (MK), } \\
\text { Albania, Kosovo }\end{array}$ & 8 & $\begin{array}{l}\text { The municipalities Jegunovce and } \\
\text { Tearce in North Macedonia, Prizren, } \\
\text { Shterpce/Štrpce and Dragash in } \\
\text { Kosovo, and the district of Kukes in } \\
\text { Albania }\end{array}$ & $\begin{array}{r}2564 \text { (311 in North } \\
\text { Macedonia, } 930 \text { in } \\
\text { Albania and } 1323 \text { in } \\
\text { Kosovo) }\end{array}$ & Sharr Mountains National Park & 533 \\
\hline Poland (PL), Belarus (BY) & 9 & $\begin{array}{l}\text { Podlaskie wojewodstvo covering } \\
\text { most of the Narew basin, and three } \\
\text { Belarusian districts }\end{array}$ & 39,800 & $\begin{array}{l}\text { Bialowieza forest World Heritage } \\
\text { Site in PL and BY (World Heritage } \\
\text { Centre/IUCN 2018) }\end{array}$ & 2391 \\
\hline Scotland (UK) & 10 & Lochaber & 4654 & Loch Sunart & 322 \\
\hline Slovakia (SK) & 11 & Trnava and Bratislava regions & $4145+2053$ & Trnava district & 741 \\
\hline Ukraine (UA), Romania & 12 & $\begin{array}{l}\text { Chernivtsi oblast and Suceava } \\
\text { county }\end{array}$ & $8097+8553$ & Putyla district & 884 \\
\hline \multicolumn{6}{|l|}{$<20 \%$ forest cover; Figure 4} \\
\hline Netherlands (NL) & 13 & Fryslan (Friesland) & 5749 & Beetsterzwaag project area & 74 \\
\hline Portugal (PT) & 14 & Évora district & 7393 & $\begin{array}{l}\text { Sítio de Monfurado, Montemor-o- } \\
\text { Novo }\end{array}$ & 240 \\
\hline Spain (ES) & 15 & Palencia province & 8052 & $\begin{array}{l}\text { Palencia Model Forest NE corner's } \\
10 \text { municipalities }\end{array}$ & 637 \\
\hline Turkey (TR) & 16 & Mersin and Karaman provinces & $15,853+9163$ & $\begin{array}{l}\text { Kösecobanli oak landscape (in } \\
\text { Gülnar municipality) }\end{array}$ & 1413 \\
\hline
\end{tabular}

methods for horizon scanning exist. These may comprise questionnaires, focus groups, and workshops, or a combination, conducted in various forms including also use of expert knowledge, issue trees, literature search, trend analysis, and scenario planning (Sutherland and Woodroof 2009, Bengston 2013). A horizon scanning is an approach to both trigger the process of knowledge production and learning with stakeholder groups, and to interpret and discuss the results from research.

In this study most of the coauthors were both academic experts involved with research or development cooperation in one or several of the 16 case study regions and hotspot landscapes, and also local citizens living in a case study region or even hotspot landscape. Together with their own professional and private networks they produced comprehensive summaries of peerreview and grey literature $(\mathrm{n}=226)$, all quoted in Appendix 1 . They, and their teams of three to four colleagues and locals, also summarized their collective knowledge about the current state and trends of traditional and novel face-to-face as well as virtual fora for collaboration, and bonding, bridging, and linking social capital forms (Szreter and Woolcock 2004; Fig. 1) supporting landscape stewardship toward functional representative green infrastructures. During the kick-off meeting to select case study areas, three workshops, and several online training sessions we developed a harmonized methodology. This approach was inspired by necessity in terms no funding for fieldwork, and rapid rural appraisal aiming at learning about rural conditions in a costeffective manner. This means ignoring what Chambers (1981) calls "inappropriate professional standards" because they are too costly, and instead applying a new rigor based on the two principles of "optimal ignorance" (knowing what it is not worth knowing), and "proportionate accuracy" (recognizing the degree of accuracy required). The lead author has worked in all case study regions, and was therefore able to recruit suitable coauthors as focal points for data collection in each hotspot landscape, as well as to support harmonization of the narratives, and compile data from the rapid assessment of fora and forms of social capital. To secure the reliability of local knowledge representing hotspot 
Fig. 3. Location of the 16 case study "hotspot" landscapes in EU (darker circles) and non-EU (lighter circles) countries on the WVS wave 6 (2010-2014) Inglehart-Welzel Cultural Map (http://www.worldvaluessurvey.org/images/

Culture Map 2017 conclusive.png), which shows two major dimensions of cross cultural variation in the world. From left to right these are survival values versus self-expression values, and bottom-up from traditional values versus secular-rational values.

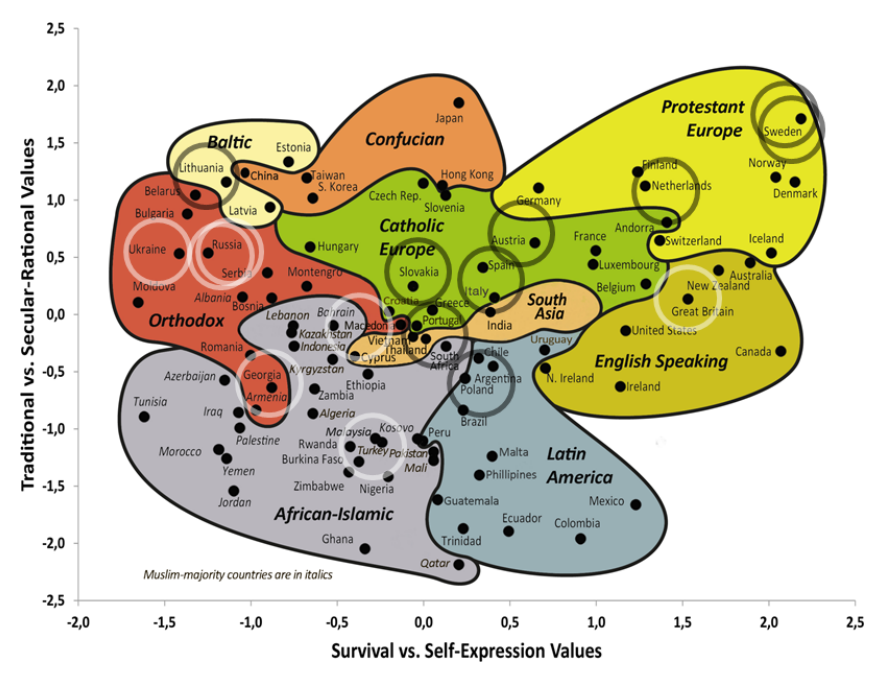

Erratum: In the original version of the pdf an incorrect copy of Fig. 3 was published. The error was corrected on 9 February 2021.

Fig. 4. Graph showing the gradient from low to high forest covers in 16 Pan-European case study regions and constituent local "hotspot" landscapes.

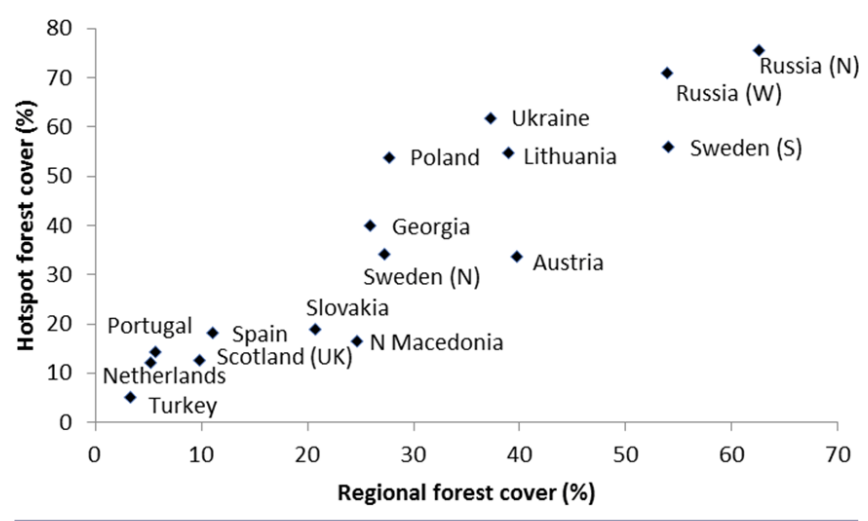

landscapes, authors of this study have a long trajectory of placebased and transdisciplinary research in their own regional and local landscape contexts, and thus have built first-hand knowledge about these areas in conjunction with local networks and actors across at least a decadal period of time. Being aware of how personal and professional bias can operate making descriptions and interpretation less accurate considering the researchers' implication in some cases studied, triangulation processes (Flick 2006) among the coauthors was conducted to contrast the narratives and estimations in order to ensure reliability. This methodology minimized the risk that the perception of fora and social capital among coauthors and their teams might be biased. This resulted in three data sets, which focus on each of the hotspot landscapes as a discrete sampling unit:

1. Concise standardized narratives about each case study region and constituent hotspot landscape (Appendix 1).

2. Estimates of the portfolios of states and trends of traditional, novel, and virtual fora for social interaction (Table 2).

3. Estimates of the states and trends of bonding, bridging and linking forms of social capital for each of the fora for social interaction (Table 3).

The rapid appraisal approach means that the precision within the study's individual hotspot landscapes most likely could be improved. Although studies about fora for social interaction and social capital focus on an area-based overview, as the hotspot landscapes in this study, specific groups may participate to different extents in different networks of interaction in different spaces and times. Demographic characteristics such as age and gender (e.g., Veenstra 2000) is one example. Use of virtual means of communication requires specific knowledge, skills, financial resources, and technology that the older generation does not always possess, especially in the former socialist countries. Settlement size and features also determine social interaction offering opportunities for enhancing social ties and bonds. Gender is an important factor influencing the kind of networks with which women and men tend to be more likely engaged, and the places and activities they attend more frequently. Historically, men have dominated the public sphere, whereas women were oriented toward socialization by developing social identity, and skills focused on care-giving roles. This implies difficulties in public space and fora for women to have their voice heard. Studies show that women are more likely to be connected in informal networks, while men's networks are more likely to be formal (Ray et al. 2017). Granovetter (1973) argued that the strength of personal ties is formed by a combination of the interaction time, the emotional intensity, the intimacy (mutual confidence), and the reciprocal services. Also Chambers $(1981,1994)$ lists a wide range of additional potential biases, especially by urban-based professionals, which we avoided, when attempting both rapid and participatory rural appraisal. Nevertheless, we assumed that the accuracy in the relation to the Pan-European focus is sufficient.

\section{Analyses}

After mapping of traditional, novel, and virtual fora for social interactions based on the narratives and rapid appraisal estimates by coauthors and their teams, each identified forum item was ranked by their occurrence as active (2), present (1), or (near) absent (0), and the trend from past (before 1980s assuming that this is before "modern" ideas about sustainable development and sustainability appeared) to present was marked as increasing $(+)$, stable (=), or decreasing (-). The same method was used to assess hotspot landscapes' social capital interactions (bonding, bridging, or linking) for traditional, novel, and virtual fora. The resulting state and trends (i.e., $0,1-, 1=, 1+, 2-, 2=, 2+$ ) were then translated to a 1-7 step ordinal Likert scale used to express the relative role of a particular variable. This was used as input data for multivariate analyses to explore regional patterns of different categories of social interactions (fora) and social capital forms on 
Table 2. Expert assessment of viability/activity of meeting places in hotspot areas belonging to one of three groups of fora (traditional, novel, and virtual). Occurrence today is marked as active (2), present (1), or (near) absent (0), and the trend from past (before 1980s ${ }^{\dagger}$ ) to present is marked as increasing (+), stable (=), or negative (-). See Table 1 and Figures 2, 3, 4 for details about the case study regions and hotspots. The Likert ranks are shown in Figure 6. PPGIS $=$ Public Participation Geographic Information Systems.

${ }^{\dagger}$ Assuming that the 1980s is before "modern" ideas about sustainable development and sustainability appeared (Brundtland, Rio etc.).

\begin{tabular}{|c|c|c|c|c|c|c|c|c|c|c|c|c|c|c|c|c|}
\hline \multirow[t]{2}{*}{ Meeting place } & \multicolumn{4}{|c|}{$>50 \%$ forest cover } & \multicolumn{8}{|c|}{$20-50 \%$ forest cover } & \multicolumn{4}{|c|}{$<20 \%$ forest cover } \\
\hline & $\begin{array}{l}\text { RU-N } \\
\text { (1) }\end{array}$ & $\begin{array}{l}\text { RU-W } \\
\text { (2) }\end{array}$ & $\begin{array}{l}\text { SE-S } \\
\text { (3) }\end{array}$ & $\begin{array}{l}\text { SE-N } \\
\text { (4) }\end{array}$ & $\begin{array}{l}\text { A } \\
(5)\end{array}$ & $\begin{array}{l}\text { GE } \\
(6)\end{array}$ & $\begin{array}{l}\text { LT } \\
\text { (7) }\end{array}$ & $\begin{array}{l}\text { MK } \\
(8)\end{array}$ & $\begin{array}{l}\text { PL } \\
\text { (9) }\end{array}$ & $\begin{array}{l}\text { UK } \\
(10)\end{array}$ & $\begin{array}{l}\text { SK } \\
(11)\end{array}$ & $\begin{array}{l}\text { UA } \\
\text { (12) }\end{array}$ & $\begin{array}{l}\text { NL } \\
\text { (13) }\end{array}$ & $\begin{array}{l}\text { PT } \\
(14)\end{array}$ & $\begin{array}{l}\text { ES } \\
(15)\end{array}$ & $\begin{array}{l}\text { TR } \\
\text { (16) }\end{array}$ \\
\hline \multicolumn{17}{|l|}{ Traditional } \\
\hline Church (and mosque) & $2+$ & $2+$ & 0 & $1=$ & $1=$ & $1=$ & $2-$ & $1-$ & $2=$ & 0 & $1-$ & $2+$ & $1-$ & $1-$ & $1-$ & $2+$ \\
\hline Village hall/Club & $1-$ & $1-$ & $1-$ & $1=$ & $1=$ & $2=$ & $2=$ & $2=$ & $1+$ & $1-$ & $1+$ & $1-$ & $2=$ & $1-$ & $1=$ & $2=$ \\
\hline Local pub/bar & $1=$ & $1=$ & 0 & $1=$ & $2=$ & 0 & 0 & $1=$ & 0 & $1-$ & $2+$ & $2+$ & $1=$ & $2-$ & $2=$ & 0 \\
\hline Café & $1-$ & $1=$ & $1+$ & $1+$ & $2=$ & 0 & $1+$ & $1=$ & 0 & $1=$ & 0 & 0 & $1=$ & $2=$ & $1+$ & $2=$ \\
\hline Market/Shop & $2=$ & $2=$ & $1=$ & $1=$ & $2=$ & $1-$ & $2-$ & $1=$ & $1-$ & 0 & $2-$ & $1+$ & 0 & $2=$ & $2=$ & $2=$ \\
\hline Public outdoor space & $2=$ & $1=$ & 0 & $1+$ & $1=$ & $2=$ & $2=$ & $2=$ & $2+$ & 0 & $1=$ & $1=$ & $1=$ & $1-$ & $2=$ & $1=$ \\
\hline Association (NGO) & $1+$ & $1+$ & $1-$ & $1=$ & $2=$ & 0 & $1+$ & $1+$ & $2+$ & $2+$ & 0 & $1+$ & $2=$ & $1-$ & $2+$ & 0 \\
\hline Festivity & $2=$ & $1=$ & $1=$ & $1=$ & $2=$ & $2=$ & $1+$ & $1=$ & $2=$ & $1=$ & $1-$ & $2=$ & $2=$ & $1-$ & $2=$ & $2=$ \\
\hline \multicolumn{17}{|l|}{ Novel } \\
\hline EU LEADER & 0 & 0 & $1+$ & $1=$ & $2=$ & $2=$ & $1+$ & $1+$ & 0 & 0 & $1+$ & 0 & 0 & 0 & $1+$ & 0 \\
\hline Biosphere Res & 0 & 0 & 0 & 0 & 0 & 0 & 0 & 0 & $1=$ & 0 & 0 & 0 & $1=$ & 0 & 0 & 0 \\
\hline Geopark & 0 & 0 & 0 & 0 & 0 & 0 & 0 & 0 & 0 & 0 & 0 & 0 & 0 & 0 & $1+$ & 0 \\
\hline Model Forest & 0 & $2-$ & 0 & 0 & 0 & 0 & 0 & 0 & 0 & 0 & $1+$ & 0 & 0 & 0 & $1+$ & 0 \\
\hline World Heritage/ Ramsar & 0 & 0 & 0 & $1=$ & $1=$ & 0 & $2=$ & 0 & $1+$ & 0 & 0 & 0 & 0 & 0 & 0 & 0 \\
\hline Development cooperation & $1+$ & $1-$ & $2+$ & $1+$ & 0 & $2+$ & $1+$ & $2+$ & $1+$ & $1-$ & $1+$ & 0 & $2+$ & 0 & 0 & 0 \\
\hline National park & 0 & 0 & $1+$ & $1=$ & 0 & $2=$ & $2=$ & $1+$ & $1-$ & 0 & 0 & $1+$ & 0 & 0 & 0 & 0 \\
\hline Research/University & $1+$ & $1+$ & $1+$ & $2-$ & $2=$ & $2=$ & $1+$ & $1-$ & $2+$ & $1+$ & $1+$ & $1+$ & $1=$ & $1+$ & $1+$ & $2+$ \\
\hline International NGO & $2+$ & $1+$ & 0 & $1+$ & $1=$ & 0 & $1=$ & $1+$ & $1+$ & 0 & $1+$ & $1+$ & 0 & 0 & 0 & $2+$ \\
\hline \multicolumn{17}{|l|}{ Virtual } \\
\hline Web pages & $2+$ & $2+$ & $1+$ & $1=$ & $2=$ & $1+$ & $2+$ & $1+$ & $1+$ & $1+$ & $2+$ & $1+$ & $1=$ & $2+$ & $1+$ & 0 \\
\hline Email/blogs & $2+$ & $2+$ & $2+$ & $1=$ & $2=$ & $1+$ & $2+$ & $1+$ & $1+$ & $1+$ & $2+$ & $1+$ & 0 & $2+$ & $1+$ & 0 \\
\hline Social media & $2+$ & $2+$ & $2+$ & $1=$ & $2=$ & $2=$ & $2+$ & $2+$ & $2+$ & $1+$ & $2+$ & $2+$ & $1=$ & $1+$ & $2+$ & $2=$ \\
\hline PPPGIS/landscape model & 0 & 0 & $1+$ & 0 & $1=$ & $1=$ & $1+$ & 0 & $1+$ & 0 & 0 & $1+$ & 0 & 0 & 0 & 0 \\
\hline Web surveys & 0 & 0 & 0 & 0 & $1=$ & 0 & $1+$ & 0 & $1+$ & 0 & $1+$ & 0 & 0 & 0 & 0 & 0 \\
\hline
\end{tabular}

the European continent. First, we used hierarchical clustering as a way to illustrate which hotspot landscapes behave similarly. Next, focusing our exploration we used principal component analysis (PCA) as a robust and much used method for illustrating complex data. The seven-step Likert scale is a violation of the condition of having continuous data, but was accepted because of the exploratory nature of this study.

\section{RESULTS}

\section{Portfolios of fora for landscape stewardship}

A total of eight traditional, nine novel, and five virtual fora were identified across the 16 hotspot landscapes (Table 2). These encompassed actors from private, public, and civil sectors. Their relative ranks were quite similar for the different traditional fora (3.3 to 4.4), but varied more for novel (1.2-4.6) and virtual (1.7-4.8) fora. Social media represented by a broad variety of communication apps and various platforms had the highest mean Likert score (5.9) of all fora (see Fig. 5).

Clustering hotspot landscapes using Ward's method (Fig. 6) resulted in three clusters: (1) one with four secular NW European countries (Scotland in the United Kingdom, the Netherlands, Sweden-N, Sweden-S) and two hotspots hosting German-funded development cooperation projects (North Macedonia and Georgia); (2) one with four countries representing catholic Europe (Spain, Austria, Portugal, Slovakia; see Fig. 3), and (3) one with post-Soviet countries (Lithuania, Poland, Ukraine, and the two Russian hotspot landscapes), and Muslim Turkey. This
Fig. 5. Histogram showing the mean Likert rank among 16 hotspot landscapes for traditional fora (left), novel fora (center), and virtual fora (right). PPGIS = Public Participation Geographic Information Systems.

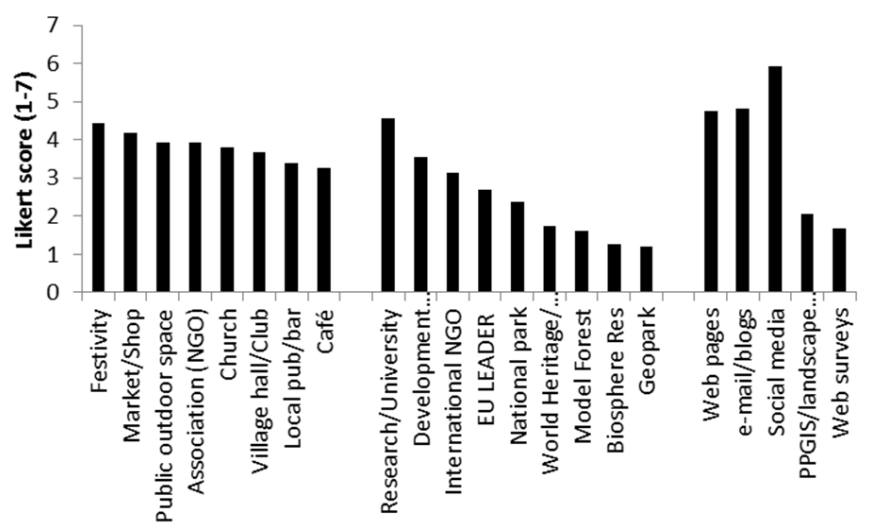

corresponds to the gradient from "self-expression and secularrational values" to "survival and traditional authority values" (sensu Inglehart 2018). A PCA analysis for the use of and trends regarding fora for social interactions (Fig. 7) showed that the first two components explained $41 \%$ of the variance $(\mathrm{PC} 1=23 \%$ with Eigenvalue 15.8 and $\mathrm{PC} 2=18 \%$ with Eigenvalue 12.6). The 
Table 3. Overview of the hotspot areas' social capital interactions (bonding, bridging, or linking) in each of the three groups of fora, assessing which is active (2), present (1), or (near) absent (0), and the trend from the past (before $1980 \mathrm{~s}^{\dagger}$ ) to present is marked as increasing $(+)$, stable (=), or negative (-). See Table 1 and Figures 2, 3, 4 for details about the case study regions and hotspots. The Likert ranks are shown in Figure 8.

${ }^{\dagger}$ Assuming that the 1980 s is before "modern" ideas about sustainable development and sustainability appeared (Brundtland, Rio etc.).

\begin{tabular}{|c|c|c|c|c|c|c|c|c|c|c|c|c|c|c|c|c|c|}
\hline \multirow[t]{2}{*}{ Fora } & \multirow[t]{2}{*}{ Social capital } & \multicolumn{4}{|c|}{$>50 \%$ forest cover } & \multicolumn{8}{|c|}{$20-50 \%$ forest cover } & \multicolumn{4}{|c|}{$<20 \%$ forest cover } \\
\hline & & $\begin{array}{l}\text { RU-N } \\
(1)\end{array}$ & $\begin{array}{l}\text { RU-W } \\
\text { (2) }\end{array}$ & $\begin{array}{l}\text { SE-S } \\
(3)\end{array}$ & $\begin{array}{l}\text { SE-N } \\
(4)\end{array}$ & $\begin{array}{l}\text { A } \\
(5) \\
\end{array}$ & $\begin{array}{l}\text { GE } \\
(6) \\
\end{array}$ & $\begin{array}{l}\text { LT } \\
(7) \\
\end{array}$ & $\begin{array}{l}\text { MK } \\
(8) \\
\end{array}$ & $\begin{array}{l}\text { PL } \\
\text { (9) }\end{array}$ & $\begin{array}{l}\text { UK } \\
(10) \\
\end{array}$ & $\begin{array}{l}\text { SK } \\
(11)\end{array}$ & $\begin{array}{l}\text { UA } \\
(12) \\
\end{array}$ & $\begin{array}{l}\text { NL } \\
(13)\end{array}$ & $\begin{array}{l}\text { PT } \\
(14)\end{array}$ & $\begin{array}{l}\text { ES } \\
(15) \\
\end{array}$ & $\begin{array}{l}\text { TR } \\
\text { (16) } \\
\end{array}$ \\
\hline \multicolumn{18}{|c|}{ Traditional } \\
\hline & Bonding & $2=$ & $2=$ & $1=$ & $1=$ & $2=$ & $2=$ & $2-$ & $2=$ & $2=$ & $2-$ & $2=$ & $2=$ & $2+$ & $2=$ & $2-$ & $2=$ \\
\hline & Bridging & $1=$ & $1=$ & $1=$ & $2-$ & $2=$ & $2=$ & $2-$ & $1=$ & $1=$ & $2-$ & $1=$ & $1=$ & $2=$ & $1-$ & $1=$ & $1=$ \\
\hline & Linking & $1=$ & $1+$ & 0 & 0 & $1=$ & $1=$ & $1=$ & $1=$ & $1=$ & $1-$ & $1=$ & $1=$ & $2=$ & $1-$ & $0+$ & $1=$ \\
\hline \multicolumn{18}{|l|}{ Novel } \\
\hline & Bonding & $1+$ & $1+$ & $2+$ & $1=$ & $1=$ & $2=$ & $1+$ & $2+$ & $2+$ & $2=$ & $2+$ & $2+$ & $2+$ & $1=$ & $1+$ & $1=$ \\
\hline & Bridging & $1+$ & $1+$ & $2+$ & $1=$ & $1=$ & $2+$ & $1+$ & $2+$ & $2+$ & $2=$ & $2=$ & $1+$ & $2+$ & $2+$ & $2+$ & $1=$ \\
\hline & Linking & $2=$ & $1+$ & $1+$ & $1+$ & $1=$ & $1+$ & $1+$ & $2+$ & $2+$ & $1+$ & $1+$ & $1+$ & $2=$ & $2+$ & $1+$ & $1=$ \\
\hline \multicolumn{18}{|c|}{ Virtual } \\
\hline & Bonding & $2+$ & $2+$ & $2+$ & $2=$ & $2=$ & $2+$ & $1+$ & $1+$ & $2+$ & $1+$ & $2=$ & $2+$ & $0=$ & $1+$ & $1+$ & $0=$ \\
\hline & Bridging & $1+$ & $1+$ & $1+$ & $1+$ & $2=$ & $2+$ & $1+$ & $1+$ & $2+$ & $1+$ & $2+$ & $1+$ & $0=$ & $1+$ & $1+$ & $0=$ \\
\hline & Linking & $2+$ & $1+$ & $1+$ & $1+$ & $1=$ & $1=$ & $1=$ & $1+$ & $1+$ & $0=$ & $1+$ & $1+$ & $0=$ & $1+$ & $1+$ & $1+$ \\
\hline
\end{tabular}

Fig. 6. Hierarchical clustering using Ward's method and Euclidian similarity index for 16 hotspot landscapes based on estimates of the types of traditional, novel, and virtual fora in each of them. Data derived from Table 2. PPGIS = Public Participation Geographic Information Systems.

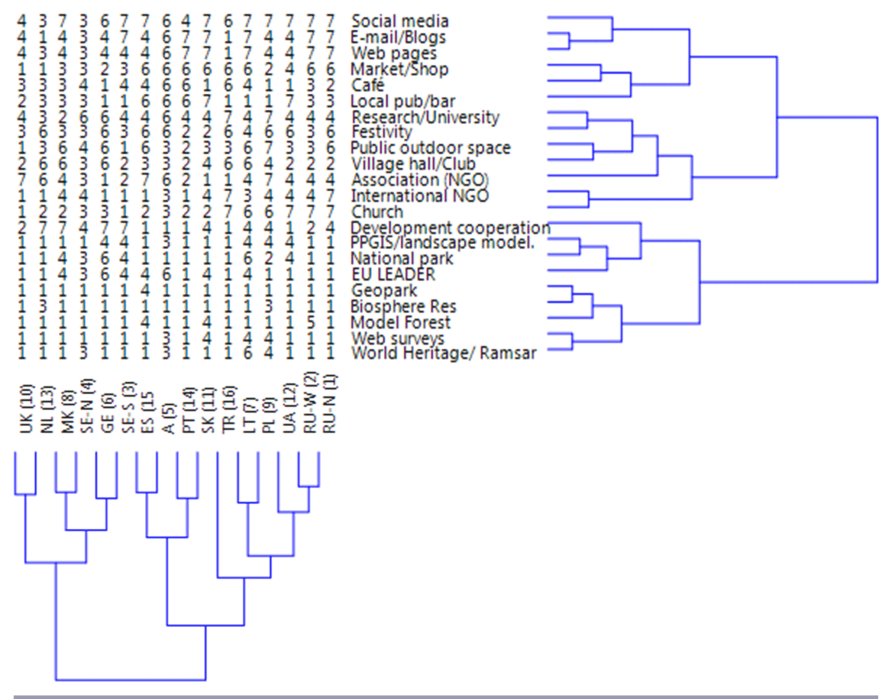

two variables most related to component 1 were local pub/bar and market/shop, and for the principal component 2 this variable was churches.

\section{Portfolios of social capital}

Across all 16 hotspot landscapes the sum of Likert rankings decreased from bonding (252) to bridging (217) and to linking (177) forms of social capital. Applying the Kruskall-Wallis test for equal medians for the three forms of social capital $(n=3 \times 16)$ showed that there was a significant difference between sample medians (chisquare 15.9, $\mathrm{p}=0.0003)$. However, there was no difference between the Likert ranks for traditional (194), novel (243), and virtual (209) fora (chi-square 5.1, $\mathrm{p}=0.07$ ). This suggests that none of the groups of fora is effective at any particular level from local bonding to linking of multiple levels.

The cluster analysis resulted in two distinct groups with subgroups in each (Fig. 8). From left to right in the first group the first subgroup included North Macedonia, Spain, and Portugal, the second subgroup included three hotspot landscapes with postSoviet legacies (Ukraine and two Russian ones), and the third subgroup with S Sweden, Georgia, Slovakia, and Poland. The second group included the Netherlands, Turkey, Scotland in the UK, Lithuania, Austria, and N Sweden. Using PCA analysis (Fig. 9) for the social capital data (Table 3) the first two components explained $53 \%$ of the variance $(\mathrm{PC} 1=29 \%$ with an Eigenvalue of 2.6 and $\mathrm{PC} 2=25 \%$ with an Eigenvalue of 2.2 ). The two variables contributing most to principal component 1 were traditional linking and traditional bonding while all three virtual social capitals were negatively related to this component. The variables contributing negatively to principal component 2 was traditional bridging capital, and all the other ones contributed positively to this component.

\section{DISCUSSION}

\section{Fora for social interaction}

This exploratory study inspired by cost-effective rapid rural appraisal (Chambers 1981) shows that the portfolios of fora with opportunities to support landscape stewardship were associated to macro-regional societal cultures across the European continent. The three clusters in the northwest, the south, and the east were explained by the relative occurrence of traditional secular vs. religious local meeting places. This matches the pattern on the Inglehart-Welzel Cultural Map (Inglehart 2018; see Fig. 3) that places countries with respect to survival values versus selfexpression values, and traditional values versus secular-rational values. However, virtual internet-based fora were the most widespread and increasingly common ones. Virtual fora for social interaction have become important for both mitigating as well as exacerbating social conflicts over land use priorities (see Appendix 1). Our results also indicate that social capital decreased from lower to higher levels of governance. Thus, local bonding social capital was the strongest across the case study landscapes, bridging was 
Fig. 7. Principal component analysis ordination (left) and variable loadings (right) for 16 hotspot landscapes' portfolios of traditional, novel, and virtual fora. Data derived from Table 2 and Figure 6.

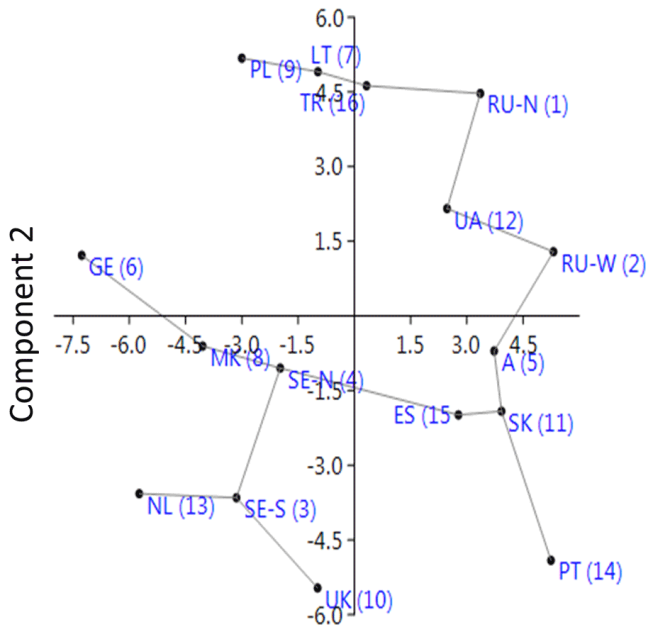

Component 1

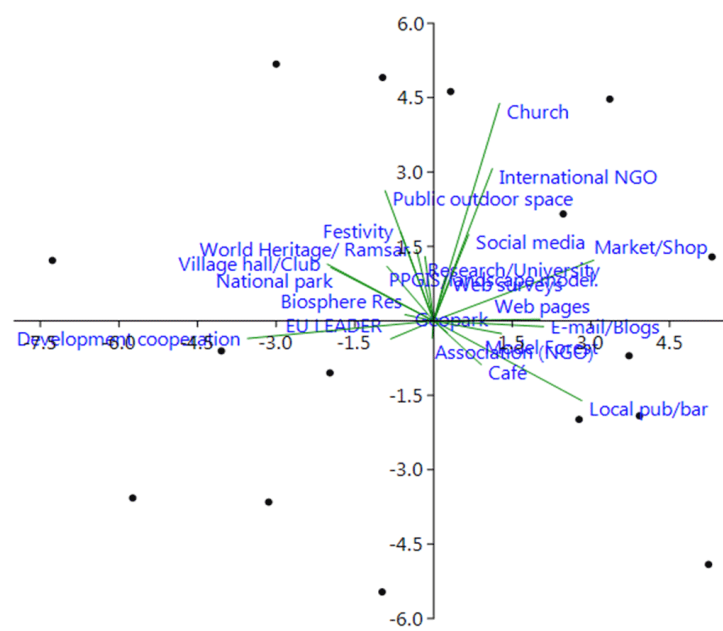

Component 1
Fig. 8. Hierarchical clustering using Ward's method and Euclidian similarity index for 16 hotspot landscapes based on estimates of the strength of bonding, bridging, and linking types of social capitals associated to traditional, novel, and virtual fora in each of them. Data derived from Table 2.

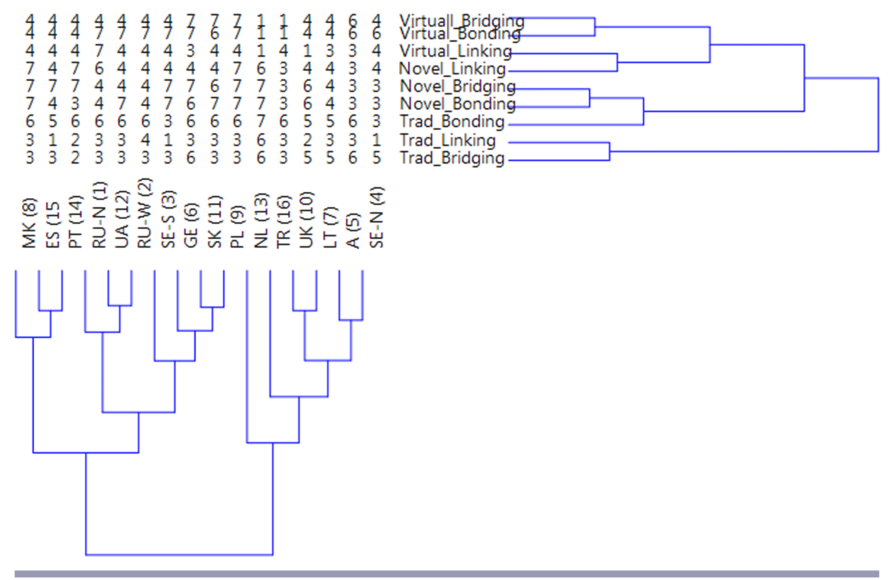

intermediate, and linking social capital was the weakest. This applied to all three groups of fora. The case study narratives in Appendix 1 provide detail to these patterns.

\section{Traditional fora}

Different forms of social interactions are part of the social structure and cultural context of landscapes' social-ecological systems, and hold systems of meanings conceived as languages, practices, and knowledge (White 2008). Fora for social interaction depend very much on the pre-existing context, which can help understand the dynamics of and relationships between social capital and landscape stewardship. Traditional fora for social interactions have diverse formats and expressions for social life, and depend on local contexts. In all hotspot landscapes some kinds of traditional fora were important for face-to-face interactions, e.g., churches, local bars and pubs, and public outdoor spaces. Traditional village systems (Sporrong 1998) remain longer in physically and economically remote rural landscapes (Angelstam et al. 2003). Examples include parts of the Alps, the Carpathian Mountains, and the Caucasus, but also remote parts of Western Europe (Butlin and Dodgshon 1998, Pinto et al. 2010).

In the Russian Empire in the eastern part of the European continent, the interchangeable terms obshchina (общи́на) and mir (миръ; the current meanings of the latter are peace or world [мир]) denoted a self-governing community of peasant households that elected its own officials and controlled local forests, fisheries, hunting grounds, and vacant lands (Hann 2003). Following the revolution, communist ideology gradually came to define landscape stewardship in Eastern Europe. The period of collectivization during the Soviet period was characterized by the expression of power and aggression, confiscation of private agricultural property, and establishment of collective farms and worker cooperatives. Responsibility for land management and use was moved from individuals to cooperatives. Thus, in former eastbloc countries like Russia (Pallot 1990), Ukraine (Marples 1984), Slovakia (Špulerová et al. 2018, Bezák and Dobrovodská 2019), and Lithuania, collectivization destroyed village community systems during the Soviet regime. Until now, the radical effects of this period are still manifested, especially among the elderly. In general, traditional meeting places are better maintained in regions with strong spiritual-religious beliefs and practices (Inglehart 2018). This was characteristic of the east European cluster including the case studies in Turkey, Lithuania, Poland, Ukraine, and Russia. The role of churches and mosques as meeting places was a common factor, and we also noted increasing attendance to mass, volunteering groups related to church, and also the restoration of old and construction of sacred buildings. Indeed, persons who are members of a church or religious community are better cared for in times of crises and have more confidence in persons and institutions (Denz and Battisti 2005). 
Fig. 9. Principal component analysis ordination (left) and variable loadings (right) for 16 hotspot landscapes' estimated strength of bonding, bridging, and linking types of social capitals. Note that the Polish and Lithuanian hotspot landscapes are identical. Data derived from Table 3 and Figure 8.
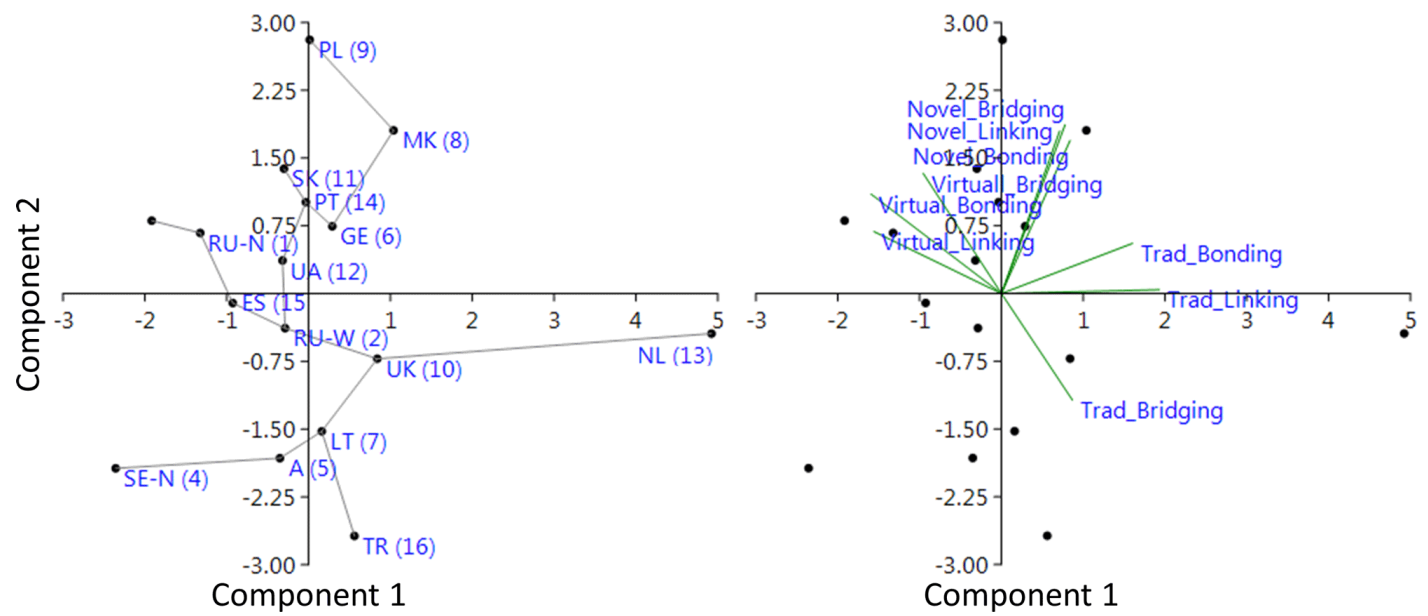

This is also the case where people are strongly rooted in local communities with robust ties to local social networks (White 2008).

\section{Novel fora}

Landscapes form coupled social and ecological systems (Matthews and Selman 2006), which are maintained or changed through many different types of actions and decisions at diverse levels of governance. The most immediate impact stems from actors possessing what Hägerstrand (2001) termed territorial skills, i.e., physically using and altering land cover units and classes. Today these skills are typically held by land owners, managers, and users who produce renewable resources, e.g., food, feed, fiber, and biofuel, or practice different kinds of resource extraction, e.g., mining. Landscapes are also influenced by indirect and distant anthropogenic demands for goods, services, and values, and local problems and actions may be the results of decisions taken in distant urban areas far outside the local rural landscape. This reinforces the need for multilevel approaches to landscapes as social-ecological systems, and new types of fora. Activities of direct actors and external drivers are generally regulated by public sector policy interventions representing socalled spatial skills such as management of landscapes for cultural reasons and those developing different kinds of infrastructures (MacFarlane 2007). Such interventions have the potential to contribute to the protection, maintenance, enhancement, and restoration of ecological, economic, social, and cultural values of rural landscapes and regions across multiple scales.

This study shows that efforts toward landscape stewardship were often present. Interaction among international environmental NGOs, forest certification schemes, and based on evidence-based knowledge about the state of green infrastructure, is demonstrated by the creation of a large $\left(>3000 \mathrm{~km}^{2}\right)$ protected area, the north Russian case study in Arkhangelsk oblast (see Appendix 1). Introduction of the global intact forest landscape (IFL) concept was the first important step around year 2000. An IFL is a "seamless mosaic of forest and naturally treeless ecosystems with no remotely detected signs of human activity and a minimum area of $500 \mathrm{~km}^{2}$ " (Potapov et al. 2017). IFLs stabilize terrestrial carbon storage, conserve biodiversity, and regulate hydrological regimes.

Additionally, a wide range of landscape approaches, such as model forest (IMFN 2008), provide tools to encourage collaboration and form partnerships that work with sustainability in local landscapes (e.g., Elbakidze et al. 2010, Angelstam et al. 2019c). Long-term social-ecological research (LTSER) platform is another example (Singh et al. 2013). This landscape approach concept focuses on a particular landscape as a coupled socialecological system with a bottom-up perspective toward knowledge production and learning by integration, research, infrastructure, and coordination of academic and nonacademic stakeholders and actors (for a review see Angelstam et al. 2019b). However, in all cases they were introduced from the outside through international NGOs (Russia), development organizations (North Macedonia, Georgia), or universities and research centers (Russia, Portugal), but less often truly bottom-up such as in the case study in southern Sweden (see Appendix 1).

The area-based development (ABD) approach (Santini et al. 2012) applied in the North Macedonian case study is a good example of international development cooperation funded by Germany, and similar to the EU LEADER system (Marquardt et al. 2012). The ADB-approach involves rural smallholders through a bottom-up approach promoting public-private and civil sector partnerships in six Western Balkans' cross-border regions of Albania, North Macedonia, Kosovo, Bosnia and Herzegovina, Serbia, and Montenegro. The approach uses a methodology, which aims at being inclusive, participatory, flexible, and supporting integration and coherence. The nucleuses are so-called stakeholder groups (SHGs). They comprise rural private smallholders, as well as relevant representatives of the public and civil sector on a local level from the target cross-border regions. The SHGs are informal forms of cooperation in which members meet on a regular basis to discuss and propose solutions for common cross-border issues, develop strategies for implementing the solutions, provide policy recommendations, as 
well as develop business ideas and mutual business cooperation. Thereby, there is a strong focus on sustainable economic growth through promotion of the principles of sustainable use of natural resources, development of short value chains, and increasing quality of local, traditional products and tourist services (Volk et al. 2017). The implementation of ABD has resulted in strengthened local ownership of local planning and development.

\section{Virtual fora}

This study indicates that virtual meeting places are gradually becoming more commonly engaging than physical ones. At the end of the 20th century, social interactions in real-time became extended beyond physical places through the Internet, adding to our vocabulary such terms as "computer-mediated communication" and "mediated communication landscape." Communication among and within individuals and communities therefore now exist in both physical places such as neighborhoods, and in cyberplaces (Wellman 2001, Driskell and Lyon 2002). Social affordances of computer and other digital devices change interactions in communities from "door-to-door" and "place-toplace" to "person-to-person" and "role-to-role" (Wellman 2001). Then the claim came that community could be regained in the facilitated environment of shared space, typically voluntary associations or working groups. The most recent candidate for regaining community is rapidly becoming the digital environment of cyberspace (Driskell and Lyon 2002).

In a virtual community, users can interact, exchange ideas, share information, provide social support, do business, direct activities, create art, play games, and participate in a political debate. In addition, virtual communication is increasingly used with the aims of supporting nature conservation and landscape governance (Arts et al. 2015, Maffey et al. 2015). All this is an indicator of the formation of a culture, which is directly opposed to the processes of maintaining the traditional linear culture (oneway communication, no feedback expected) and the values it represents. Digital media and modern technologies seem to prevail and suppress traditional cultural values and their content (Baltezarevic et al. 2019). Generally, communities are social structures that enable groups of people to share knowledge and resources in support of collaborative action. Different communities grow around different types of practice. Fischer (2001) and Fischer et al. (2007) defined two types, namely, (1) communities of practice, i.e., homogeneous groups of people who share a professional practice and a professional interest, and (2) communities of interest, i.e., heterogeneous groups of people (typically coming from different disciplines) who share a common interest. In addition, individuals commonly use virtual means of person-to-person communication (Fig. 10; Rosenfeld et al. 2019). Unlike traditional meeting places, which remain the same for centuries, virtual meeting places over the past decade changed from a handful of distinct forms of social media communication (phone calls, email, texts) to hundreds of communication apps. Mobile instant messaging (MIM) alone comprises a wide variety of applications, including Messenger, WhatsApp, iMessage, KakaoTalk, WeChat, Line, Viber, Vkontakte, and more (Nouwens et al. 2017). Platforms including Facebook, Amazon Marketplace, Uber, AirBnB, and YouTube are well-developed, and are used for not only personal interests but also serving professional needs. The most advanced among CoPs are known for using various cyberplaces, even collaborative virtual environments such as 3D simulations (Churchill and Snowdon 1998, Johnson 2001, Kimble and Hildreth 2005, Dudezert et al. 2006, Eustáquio and de Sousa 2019). However, social media can be a "double-edged sword." On the one hand, its low cost, easy access, and rapid dissemination of information lead people to seek out and consume information from a wide range of social media. On the other hand, it enables the prevalence of "fake news", i.e., low quality news with intentionally false information (Shu et al. 2017), but nevertheless resulting in widespread real-world impact. A prominent example is the U.S. presidential election campaign in 2016, when social media platforms like Twitter were increasingly used as direct sources of news, thus bypassing the editorial media (Enli 2017).

Fig. 10. Overview of the main types of activities realized via virtual meeting places for individuals, communities of interest (CoIs), and communities of practice (CoPs).

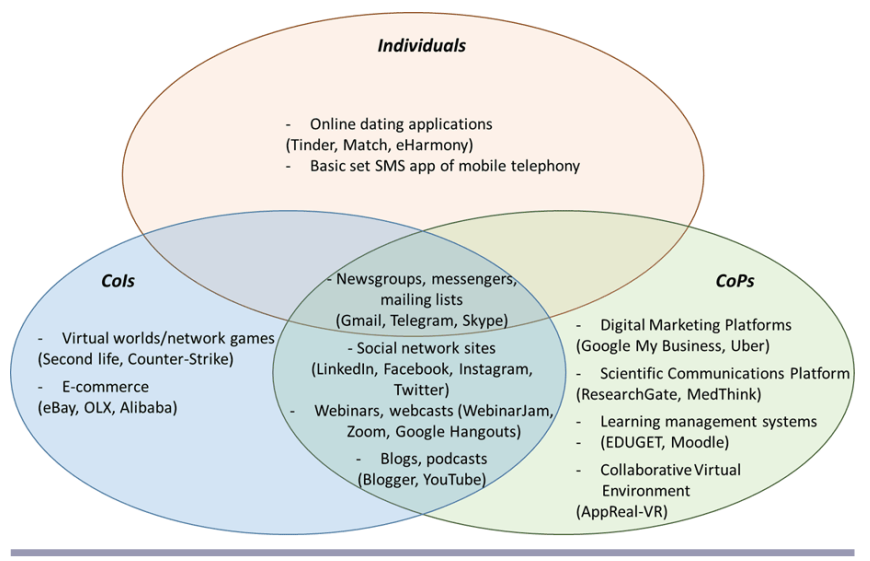

\section{Social capital}

This study's approach inspired by rapid rural appraisal confirms that regional differences in social relationships are associated to historical legacies and the resulting and cultural values (see Welzl 2013, Inglehart 2018). For example, Lee et al. (2005) found that in Scotland networks of crofters, and in Sweden voluntary and leisure associational practices, were important as such social networks. Social capital, especially in remote areas plays a strong role. For example, in rural Ukraine, if someone gets ill, the whole village will collect money to help to treat that person. Similarly, in Poland, in case of house fire, spontaneous financial support to its victims is offered from all members of community, irrespective of religious, social, or political differences. Under a totalitarian regime Russian communities were disintegrated, but in recent time the formation and expansion of horizontal social ties has been strengthened. That is due to expansion of social media.

Social capital can, however, also decline. Lately, social capital innovation has been examined regarding its capacity to revitalize forest-dependent communities across Europe, with a focus on marginalized rural areas (Nijnik et al. 2018, Nijnik and Sarkki 2019, Nijnik et al. 2019). The implications for such communities concerning aspects such as pragmatism (Sarkki et al. 2017a), equity (Sarkki et al. 2017b), and improved participatory approaches (Sarkki et al. 2019) have also been identified as extremely relevant for securing innovation and ultimately social cohesion and innovation. Both cohesion and innovation are 
considered as prerequisites for rendering landscape stewardship models more effective for pursuing sustainable local and territorial development. In spite of not being planned as supporting development actions toward sustainable landscapes, social networks may therefore make valuable contributions to social capital and economic life.

Linking meeting places, social capital, and landscape stewardship The Pan-European pattern of relationships between fora for social interactions and social capital that we identified can guide current approaches and adapt to future trajectories for landscape stewardship. The ecosystem services framework to link natural capital and human well-being aims to encourage ecological sustainability through political-economic decisions. However, this framework has been criticized for not capturing the complexity of social-ecological interactions (Norgaard 2010, Díaz et al. 2015). This is an obstacle for coping with current grand challenges for landscape stewardship supporting biodiversity conservation and supply of multiple ecosystem services (e.g., Musche et al. 2019). This also applies to green infrastructures aimed at promoting naturalness in forest ecosystems, as well as biocultural values in traditional multifunctional cultural landscapes (Cocks 2006). By combining evidence-based knowledge about the state and trends of ecosystems with partnerships for landscape stewardship, landscape concepts and approaches can help resolve the integrative and operational gaps encountered in the ecosystem services framework (e.g., Maes et al. 2018, Angelstam et al. 2019a). Although place-based research using landscape concepts can help to develop more sustainable alternatives for land management, scaling up different landscape approach initiatives toward a generalized powerful landscape stewardship approach and fostering collaborations among initiatives, remain paramount challenges (Cohen-Shacham et al. 2019). We can look to examples such as sustainable multifunctional forest management for reference, which refers to the necessity for new forms of governance (Rametsteiner 2009, Sarvašová et al. 2014). Three main approaches are in place for European forest governance (Pülzl et al. 2013): a legislative approach that follows traditional top-down models, a mixed approach based on cooperation and prioritization of information sharing (Pülzl and Lazdinis 2011, Lazdinis et al. 2019), and soft modes of governance (Kleinschmit 2012). There is thus no panacea on how to translate theories about landscape and social capital to generally applicable landscape approach practices, but it is necessary to develop as rich and diverse an understanding as possible to equip ourselves to begin to address these challenges.

However, there are major challenges for collective action aimed at accommodating multiple, often rival, benefits from landscapes (Thellbro et al. 2017). In particular, the necessary collaborative planning suffers from the lack of coordination between the involved legal frameworks as well as deficiency in local planning resources and limited skills (e.g., Elbakidze et al. 2015). Specifically, these include stakeholder/actor-specific institutional legacies, values, and norms, securing long-term funding for facilitation, and continuous knowledge production and learning. Necessary conditions for developing place-based knowledge production and learning, representing different social-ecological contexts include: (1) sufficient time for developing collaborative capacity as an iterative process (Hirsch Hadorn et al. 2008, Singh et al. 2013); i.e., a "gyroscope" sensu Lee (1993), (2) production of knowledge about states and trends of ecological and social systems involving both quantitative and qualitative methods; i.e., a "compass" sensu Lee (1993), and (3) transdisciplinarity built on coordination among academic disciplines and nonacademic participants (Hirsch Hadorn et al. 2008). The critical need of having committed persons as visionaries, project leaders, and holders of knowledge and key project skills to champion a process is well documented (e.g., Poon and Wagner 2001, Hahn et al. 2006). Dawson et al. (2017) found that successful project leaders' experiences applied a range of strategies including dividing project size and complexity into smaller short-term subtasks, securing visibility of social benefits and public utility from project achievements, and the key role of pedagogical communication.

To conclude, this study combines the social capital framework and its three forms of bonding, bridging, and linking capitals, with an innovative approach that considers different traditional, novel, and virtual fora for social interactions, and how these aspects combined can promote landscape stewardship in the context of green infrastructures. This study stresses that PanEuropean social-ecological contexts can be divided into distinct clusters with respect to the portfolios of different fora with the potential to support landscape stewardship. Hence, the diversity of landscape and environmental histories, land ownership, legacies of governance/government, cultural meanings, and socioeconomic situations call for regionally adapted solutions for governance and management of green infrastructure (e.g., Bezák and Dobrovodská 2019). Results from our 16 local hotspot landscapes across the European continent also showed that the bonding and bridging forms of social capital were strongest. In contrast, linking social capital involving multiple levels of governance was the weakest. Sharing knowledge based on comparative studies about factors of importance for landscape stewardship, as is the focus of this study, can strengthen linking social capital. Landscape stewardship also, however, needs to be underpinned by evidence-based knowledge about how to sustain green infrastructures based on both forest naturalness and cultural landscape values. Therefore, both sustainable development as a social system process (Baker 2006, Baker and Mehmood 2015), and sustainability as what societies agree on and aim at with regard to their futures (Norton 2005), need to be included. Application of fora for transdisciplinary landscape concepts and approaches, which emphasize human-environment interactions, governance, and stewardship with both nonacademic participants and researchers (Angelstam et al. 2019a, Axelsson et al. 2020) can support this.

Responses to this article can be read online at: https://www.ecologyandsociety.org/issues/responses. $\mathrm{php} / 12110$

\section{Acknowledgments:}

This study was carried out as an AlterNet High Impact Action based on a travel grant to Per Angelstam. Other key funding was received from FORMAS (grant 2017:1342) to Per Angelstam, VEGA (grant 2/0078/18) to Robert Kanka and Zita Izakovičová, and LIAISON-H2020 (grant agreement No 773418) to José Muñoz- 
Rojas. We thank Serdar Göktepe and the forestry administration in Gülnar for arranging the kick-off meeting in the Turkish case study, and Claudia Von Brömssen and Alison Gray for discussions about analytic methods. Sylvia Ackerl, Irena Dzimrevska, Boban Ilic, Aleksandr Karpov, Katerina Kolemisevska, Hubert Malin, Benjamin Mohr, Vladimir Naumov, Zymantas Morkvenas, Darren Moseley, Louise Sing, and Anastasia Yang made valuable contributions to the narratives in the Appendix.

\section{Data Availability:}

All data are in the paper, and the associated Appendix

\section{LITERATURE CITED}

Acha, A., and H. S. Newing. 2015. Cork oak landscapes, promised or compromised lands? A case study of a traditional cultural landscape in Southern Spain. Human Ecology 43(4):601-611. https://doi.org/10.1007/s10745-015-9768-7

Adler, S. P., and S. K. Kwon. 2002. Social capital: prospects for a new concept. Academy of Management Review 27:17-40. https:// doi.org/10.5465/amr.2002.5922314

Agger, A., and J. O. Jensen. 2015. Area-based initiatives - and their work in bonding, bridging and linking social capital. European Planning Studies 23(10):2045-2061. https://doi. org/10.1080/09654313.2014.998172

Agnoletti, M., editor. 2006. The conservation of cultural landscapes. CAB International, Wallingford, UK.

Angelstam, P., R. Axelsson, M. Elbakidze, L. Laestadius, M. Lazdinis, M. Nordberg, I. Pătru-Stupariu, and M. Smith. 2011. Knowledge production and learning for sustainable forest management: Pan-European landscapes as a time machine. Forestry 84(5):581-596. https://doi.org/10.1093/forestry/cpr048

Angelstam, P., L. Boresjö-Bronge, G. Mikusiński, U. Sporrong, and A. Wästfelt. 2003. Assessing village authenticity with satellite images: a method to identify intact cultural landscapes in Europe. Ambio 32(8):594-604. https://doi.org/10.1579/0044-7447-32.8.594

Angelstam, P., M. Elbakidze, R. Axelsson, A. Khoroshev, B. Pedroli, M. Tysiachniouk, and E. Zabubenin. 2019c. Model forests in Russia as landscape approach: demonstration projects or initiatives for learning towards sustainable forest management? Forest Policy and Economics 101:96-110. https://doi.org/10.1016/ j.forpol.2019.01.005

Angelstam, P., M. Grodzynskyi, K. Andersson, R. Axelsson, M. Elbakidze, A. Khoroshev, I. Kruhlov, and V. Naumov. 2013. Measurement, collaborative learning and research for sustainable use of ecosystem services: landscape concepts and Europe as laboratory. Ambio 42(2):129-145. https://doi.org/10.1007/ s13280-012-0368-0

Angelstam, P., M. Manton, M. Elbakidze, F. Sijtsma, M. Adamescu, N. Avni, P. Beja, P. Bezak, I. Zyablikova, F. Cruz, V. Bretagnolle, R. Díaz-Delgado, B. Ens, M. Fedoriak, G. Flaim, S. Gingrich, M. Lavi-Neeman, S. Medinets, V. Melecis, J. MuñozRojas, J. Schäckermann, A. Stocker-Kiss, H. Setälä, N. Stryamets, M. Taka, G. Tallec, U. Tappeiner, J. Törnblom, and T. Yamelynets. 2019b. LTSER platforms as a place-based transdisciplinary research infrastructure: learning landscape approach through evaluation. Landscape Ecology 34(7):1461-1484. https://doi. org/10.1007/s10980-018-0737-6

Angelstam, P., M. Manton, T. Yamelynets, M. Fedoriak, A.-C. Albulescu, F. Bravo, F. Cruz, B. Jaroszewicz, M. Kavtarishvili, J. Muñoz-Rojas, F. Sijtsma, C.-L. Washbourne, M. Agnoletti, D. Dobrynin, Z. Izakovicova, N. Jansson, R. Kanka, L. Kopperoinen, M. Lazdinis, M. Metzger, B. van der Moolen, D. Özut, D. Pavloska Gjorgieska, N. Stryamets, A. Tolunay, T. Turkoglu, A. Zagidullina. 2021. Maintaining natural and traditional cultural green infrastructures across Europe: learning from historic and current landscape transformations. Landscape Ecology 36:637-663. https://doi.org/10.1007/s10980-020-01161-y

Angelstam, P., J. Munoz-Rojas, and T. Pinto-Correia. 2019a. Landscape concepts and approaches foster learning about ecosystem services. Landscape Ecology 34(7):1445-1460. https:// doi.org/10.1007/s10980-019-00866-Z

Angelstam, P., V. Naumov, M. Elbakidze, M. Manton, J. Priednieks, and Z. Rendenieks. 2018. Wood production and biodiversity conservation are rival forestry objectives in Europe's Baltic Sea Region. Ecosphere 9(3):e02119. https://doi. org/10.1002/ecs2.2119

Angelstam, P., J.-M. Roberge, A. Lõhmus, M. Bergmanis, G. Brazaitis, M. Dönz-Breuss, L. Edenius, Z. Kosinski, P. Kurlavicius, V. Lârmanis, M. Lûkins, G. Mikusinski, E. Račinskis, M. Strazds, and P. Tryjanowski. 2004. Habitat modelling as a tool for landscape-scale conservation - a review of parameters for focal forest birds. Ecological Bulletins 51:427-453.

Antrop, M. 2004. Landscape change and the urbanization process in Europe. Landscape and Urban Planning 67(1-4):9-26. https:// doi.org/10.1016/S0169-2046(03)00026-4

Arts, B., M. Buizer, L. Horlings, V. Ingram, C. van Oosten, and P. Opdam. 2017. Landscape approaches: a state-of-the-art review. Annual Review of Environment and Resources 42:439-463. https:// doi.org/10.1146/annurev-environ-102016-060932

Arts, K., R. van der Wal, and W. M. Adams. 2015. Digital technology and the conservation of nature. Ambio 44:661-673. https://doi.org/10.1007/s13280-015-0705-1

Axelsson, R., M. Ljung, M. Blicharska, M. Frisk, M. Henningsson, G. Mikusiński, L. Folkeson, G. Göransson, S. Jönsson-Ekström, A. Sjölund, J. Skoog, J. Törnblom, and P. Angelstam. 2020. The challenge of transdisciplinary research: a case study of learning by evaluation for sustainable transport infrastructures. Sustainability 12:6995. https://doi.org/10.3390/ su12176995

Baker, S. 2006. Sustainable development. Routledge, London, UK.

Baker, S., and A. Mehmood. 2015. Social innovation and the governance of sustainable places. Local Environment 20 (3):321-334. https://doi.org/10.1080/13549839.2013.842964

Baltezarevic, R., B. Baltezarevic, P. Kwiatek, and V. Baltezarevic. 2019. The impact of virtual communities on cultural identity. Symposion 6(1):7-22. https://doi.org/10.5840/symposion2019611

Barnaud, C., E. Corbera, R. Muradian, N. Salliou, C. Sirami, A. Vialatte, J.-P. Choisis, N. Dendoncker, R. Mathevet, C. Moreau, 
V. Reyes-García, M. Boada, M. Deconchat, C. Cibien, S. Garnier, R. Maneja, and M. Antona. 2018. Ecosystem services, social interdependencies, and collective action: a conceptual framework. Ecology and Society 23(1):15. https://doi. org/10.5751/es-09848-230115

Bengston, D. N. 2013. Horizon scanning for environmental foresight: a review of issues and approaches. General Technical Report NRS-121. U.S. Forest Service, Northern Research Station, Newtown Square, Pennsylvania, USA. https://doi. org/10.2737/NRS-GTR-121

Bezák, P., and M. Dobrovodská. 2019. Role of rural identity in traditional agricultural landscape maintenance: the story of a post-communist country. Agroecology and Sustainable Food Systems 43(1):3-20. https://doi.org/10.1080/21683565.2018.1516711

Bieling, C., and T. Plieninger, editors. 2017. The science and practice of landscape stewardship. Cambridge University Press, Cambridge, UK. https://doi.org/10.1017/9781316499016

Bijker, R. A., N. Mehnen, F. J. Sijtsma, and M. N. Daams. 2014. Managing urban wellbeing in rural areas: the potential role of online communities to improve the financing and governance of highly valued nature areas. Land 3(2):437-459. https://doi. org/10.3390/land3020437

Bijker, R. A., and F. J. Sijtsma. 2017. A portfolio of natural places: using a participatory GIS tool to compare the appreciation and use of green spaces inside and outside urban areas by urban residents. Landscape and Urban Planning 158:155-165. https://doi. org/10.1016/j.landurbplan.2016.10.004

Braat, L. C., and R. de Groot. 2012. The ecosystem services agenda: bridging the worlds of natural science and economics, conservation and development, and public and private policy. Ecosystem Services 1:4-15 https://doi.org/10.1016/j.ecoser.2012.07.011

Bubalo, M., B. T. van Zanten, and P. H. Verburg. 2019. Crowdsourcing geo-information on landscape perceptions and preferences: a review. Landscape and Urban Planning 184:101-111. https://doi.org/10.1016/j.landurbplan.2019.01.001

Butlin, R. A., and R. A. Dodgshon, editors. 1998. An historical geography of Europe. Oxford University Press, Oxford, UK.

Chambers, R. 1981. Rapid rural appraisal: rationale and repertoire. Public Administration and Development 1(2):95-106. https://doi.org/10.1002/pad.4230010202

Chambers, R. 1994. The origins and practice of participatory rural appraisal. World Development 22(7):953-969. https://doi. org/10.1016/0305-750X(94)90141-4

Churchill, E. F., and D. Snowdon. 1998. Collaborative virtual environments: an introductory review of issues and systems. Virtual Reality 3(1):3-15. https://doi.org/10.1007/BF01409793

Cocks, M. 2006. Biocultural diversity: moving beyond the realm of 'indigenous' and 'local' people. Human Ecology 34(2):185-200. https://doi.org/10.1007/s10745-006-9013-5

Cohen-Shacham, E., A. Andrade, J. Dalton, N. Dudley, M. Jones, C. Kumar, S. Maginnis, S. Maynard, C. R. Nelson, F. G. Renaud, R. Welling, and G. Walters. 2019. Core principles for successfully implementing and upscaling nature-based solutions. Environmental Science \& Policy 98:20-29. https://doi.org/10.1016/j.envsci.2019.04.014

Costanza, R., and H. E. Daly. 1992. Natural capital and sustainable development. Conservation Biology 6(1):37-46. https://doi.org/10.1046/j.1523-1739.1992.610037.x

Daams, M. N., and F. J. Sijtsma. 2013. Planting the SEED: towards a spatial economic ecological database for a shared understanding of the Dutch Wadden area. Journal of Sea Research 82:153-164. https://doi.org/10.1016/j.seares.2012.12.002

Dawson, L., M. Elbakidze, P. Angelstam, and J. Gordon. 2017. Governance and management dynamics of landscape restoration at multiple scales: learning from successful environmental managers in Sweden. Journal of Environmental Management 197:24-40. https://doi.org/10.1016/i.jenvman.2017.03.019

Denz, H., and M. Battisti. 2005. Sozialkapital in Vorarlberg. Studie im Auftrag des Büro für Zukunftsfragen, Amt der Vorarlberger Landesregierung, Fachhochschule Vorarlberg, Dornbirn, Austria. [online] URL: http://cdn1.vol.at/2005/11/ Studie zur_Entwicklung des Sozialkapitals in_Vorarlberg.pdf

Díaz, S., S. Demissew, J. Carabias, C. Joly, M. Lonsdale, N. Ash, A. Larigauderie, J. R. Adhikari, S. Arico, A. Báldi, et al. 2015. The IPBES conceptual framework - connecting nature and people. Current Opinion in Environmental Sustainability 14:1-16. https://doi.org/10.1016/j.cosust.2014.11.002

Driskell, R. B., and L. Lyon. 2002. Are virtual communities true communities? Examining the environments and elements of community. City \& Community 1(4):373-390. https://doi. org/10.1111/1540-6040.00031

Duckett, D., D. Feliciano, J. Martin-Ortega, and J. Munoz-Rojas. 2016. Tackling wicked environmental problems: the discourse and its influence on praxis in Scotland. Landscape and Urban Planning 154:44-56. https://doi.org/10.1016/j.landurbplan.2016.03.015

Dudezert, A., H. Heibült, and I. Boughzala. 2006. Virtual professional communities and their role for knowledge management. In A. Oberwies, F. Feltz, B. Otjacques, and N. Poussing, editors. AIM 2006 - Information Systems and Collaboration: State of the Art and Perspectives; best papers of the 11th International Conference of the Association Information and Management (AIM), Luxembourg, June 8-9.

Elands, B. H., and K. F. Wiersum. 2001. Forestry and rural development in Europe: an exploration of socio-political discourses. Forest Policy and Economics 3(1-2):5-16. https://doi. org/10.1016/S1389-9341(00)00027-7

Elbakidze, M., and P. Angelstam. 2007. Implementing sustainable forest management in Ukraine's Carpathian Mountains: the role of traditional village systems. Forest Ecology and Management 249:28-38. https://doi.org/10.1016/j.foreco.2007.04.003

Elbakidze, M., P. K. Angelstam, C. Sandström, and R. Axelsson. 2010. Multi-stakeholder collaboration in Russian and Swedish model forest initiatives: adaptive governance toward sustainable forest management? Ecology and Society 15(2):14. https://doi. org/10.5751/ES-03334-150214

Elbakidze, M., L. Dawson, K. Andersson, R. Axelsson, P. Angelstam, I. Stjernquist, S. Teitelbaum, P. Schlyter, and C. 
Thellbro. 2015. Is spatial planning a collaborative learning process? A case study from a rural-urban gradient in Sweden. Land Use Policy 48:270-285. https://doi.org/10.1016/j. landusepol.2015.05.001

Enli, G. 2017. Twitter as arena for the authentic outsider: exploring the social media campaigns of Trump and Clinton in the 2016 US presidential election. European Journal of Communication 32(1):50-61. https://doi.org/10.1177/0267323116682802

Erixon, S. 1946. Kila. En östgötsk by. En byundersökning 1912-13. Institutet för folklivsforskning, Stockholm, Sweden.

Erixon, S. 1960. Svenska byar utan systematisk reglering: En jämförande historisk undersökning. Nordiska museet, Stockholm, Sweden.

European Commission. 2013. Green infrastructure (GI) enhancing Europe's natural capital. European Commission: Environment, Brussels, Belgium.

Eustáquio, L., and C. C. de Sousa. 2019. Creative collaborative virtual environments. Pages 461-473 in M. Khosrow-Pour, editor. Advanced methodologies and technologies in artificial intelligence, computer simulation, and human-computer interaction. IGI Global, Hershey, Pennsylvania, USA. https://doi.

org/10.4018/978-1-5225-7368-5.ch034

Ferragina, E. 2012. Social capital in Europe: a comparative regional analysis. Edward Elgar Publishing, Cheltenham, UK.

Fischer, G. 2001. Communities of interest: learning through the interaction of multiple knowledge systems. Pages 1-14 in 24th Annual Information Systems Research Seminar in Scandinavia (IRIS'24), Ulvik, Norway.

Fischer, G., M. Rohde, and V. Wulf. 2007. Community-based learning: the core competency of residential, research-based universities. International Journal of Computer-Supported Collaborative Learning 2(1):9-40. https://doi.org/10.1007/ s11412-007-9009-1

Flick, U. 2006. An introduction to qualitative research. SAGE, London, UK.

Forest Europe. 2015. Madrid Ministerial Declaration. 25 years together promoting Sustainable Forest Management in Europe. Forest Europe, Bonn, Germany. [online] URL: https://www. foresteurope.org/sites/default/files/ELM 7MC 22015 MinisterialDeclaration adopted $\% 20(2)$.pdf

Garrido, P., M. Elbakidze, P. Angelstam, T. Plieninger, F. Pulido, G. Moreno. 2017. Stakeholder perspectives of wood pasture ecosystem services: a case study from Iberian dehesas. Land Use Policy 60:324-333. https://doi.org/10.1016/j.landusepol.2016.10.022

Gibbons, M., C. Limoges, H. Nowotny, S. Schwartzman, P. Scott, and M. Trow. 1994. Thenew production of knowledge: the dynamics of science and research in contemporary societies. SAGE, London, UK.

Granovetter, M. S. 1973. The strength of weak ties. American Journal of Sociology 78(6):1360-1380. https://doi.org/10.1086/225469
Guimarães, M. H., N. Guiomar, D. Surová, S. Godinho, M. T. Pinto-Correia, A. Sandberg, F. Ravera, and M. Varanda. 2018. Structuring wicked problems in transdisciplinary research using the social-ecological systems framework: an application to the montado system, Alentejo, Portugal. Journal of Cleaner Production 191:417-428. https://doi.org/10.1016/j.jclepro.2018.04.200

Hägerstrand, T. 2001. A look at the political geography of environmental management. Pages 35-56 in A. Buttimer, editor. Sustainable landscapes and lifeways. Scale and appropriateness. Cork University Press, Cork, Ireland.

Hahn, T., P. Olsson, C. Folke, and K. Johansson. 2006. Trustbuilding, knowledge generation and organizational innovations: the role of a bridging organization for adaptive comanagement of a wetland landscape around Kristianstad, Sweden. Human Ecology 34(4):573-592. https://doi.org/10.1007/s10745-006-9035$\underline{\mathrm{Z}}$

Hann, C. 2003. The postsocialist agrarian question: property relations and the rural condition. LIT Verlag, Münster, Germany.

Hartel, T., and T. Plieninger, editors. 2014. European woodpastures in transition. A social-ecological approach. Routledge, London, UK. https://doi.org/10.4324/9780203797082

Hilbers, A. M., F. J. Sijtsma, T. Busscher, and J. Arts. 2019. Understanding added value in integrated transport planning: exploring the framework of intelligence, design and choice. Journal of Environmental Assessment Policy and Management 21 (3):1950011. https://doi.org/10.1142/S146433321950011X

Hirsch Hadorn, G. H., H. Hoffmann-Riem, S. Biber-Klemm, W. Grossenbacher-Mansuy, D. Joye, C. Pohl, U. Wiesmann, and E. Zemp, editors. 2008. Handbook of transdisciplinary research. Springer, Dordrecht, The Netherlands. https://doi. org/10.1007/978-1-4020-6699-3

Huntington, S. P. 1997. The clash of civilizations and the remaking of world order. Penguin Books India, New Delhi, India.

Inglehart, R. F. 2018. Cultural evolution. People's motivations are changing, and reshaping the world. Cambridge University Press, Cambridge, UK. https://doi.org/10.1017/9781108613880

Intergovernmental Science-Policy Platform on Biodiversity and Ecosystem Services (IPBES). 2019. Global assessment report on biodiversity and ecosystem services of the Intergovernmental Science-Policy Platform on Biodiversity and Ecosystem Services. E. S. Brondizio, J. Settele, S. Díaz, and H. T. Ngo, editors. IPBES Secretariat, Bonn, Germany.

International Model Forest Network (IMFN). 2008. Model forest development guide. IMFN Secretariat, Ottawa, Ontario, Canada.

Johnson, C. M. 2001. A survey of current research on online communities of practice. The Internet and Higher Education 4 (1):45-60. https://doi.org/10.1016/S1096-7516(01)00047-1

Kimble, C., and P. Hildreth. 2005. Virtual communities of practice. Pages 2991-2995 in M. Khosrow-Pour, editor. Encyclopedia of information science and technology. Idea Group, Hershey, Pennsylvania, USA. https://doi.org/10.4018/978-1-59140-553-5. $\underline{\operatorname{ch} 532}$ 
Kleinschmit, D. 2012. Confronting the demands of a deliberative public sphere with media constrains. Forest Policy and Economics 16:71-80. https://doi.org/10.1016/j.forpol.2010.02.013

Lasanta, T., J. Arnáez, N. Pascual, P. Ruiz-Flaño, M. P. Errea, and N. Lana-Renault. 2017. Space-time process and drivers of land abandonment in Europe. Catena 149:810-823. https://doi. org/10.1016/j.catena.2016.02.024

Lazdinis, M., P. Angelstam, and H. Pülzl. 2019. Towards sustainable forest management in the European Union through polycentric forest governance and integrated landscape approach. Landscape Ecology 34(7):1737-1749. https://doi.org/10.1007/ s10980-019-00864-1

Lee, K. N. 1993. Compass and gyroscope: integrating science and politics for the environment. Island, Washington, D.C., USA.

Lee, J., A. Árnason, A. Nightingale, and M. Shucksmith. 2005. Networking: social capital and identities in European rural development. Sociologia Ruralis 45(4):269-283. https://doi. org/10.1111/j.1467-9523.2005.00305.x

MacFarlane, R. 2007. Multi-functional landscapes: conceptual and planning issues for the countryside. Pages 138-166 in J. F. Benson and M. Roe, editors. Landscape and sustainability. Second edition. Routledge, New York, New York, USA.

Maes, J., A. Teller, M. Erhard, B. Grizzetti, J. I. Barredo, M. L. Paracchini, S. Condé, F. Somma, A. Orgiazzi, A. Jones, A. Zulian, S. Vallecilo, J. E. Petersen, D. Marquardt, V. Kovacevic, D. Abdul Malak, A. I. Marin, B. Czúcz, A. Mauri, P. Loffler, A. Bastrup Birk, K. Biala, T. Christiansen, and B. Werner. 2018. Mapping and assessment of ecosystems and their services: an analytical framework for mapping and assessment of ecosystem condition in $E U$. Publications Office of the European Union, Luxembourg. [online] URL: https://catalogue.biodiversity.europa.eu/uploads/ document/file/1673/5th MAES report.pdf

Maffey, G., H. Homans, K. Banks, and K. Arts. 2015. Digital technology and human development: a charter for nature conservation. Ambio 44(4):527-537. https://doi.org/10.1007/ $\underline{\text { s13280-015-0703-3 }}$

Marples, D. R. 1984. The kulak in post-war USSR: the west Ukrainian example. Soviet Studies 36(4):560-570. https://doi. org/10.1080/09668138408411555

Marquardt, D., J. Moellers, and G. Buchenrieder. 2012. Social networks and rural development: LEADER in Romania. Sociologia Ruralis 52(4):398-431. https://doi.org/10.1111/ j.1467-9523.2012.00571.x

Matthews. R., and P. Selman. 2006. Landscape as a focus for integrating human and environmental processes. Journal of Agricultural Economics 57(2):199-212. https://doi.org/10.1111/ j.1477-9552.2006.00047.x

Millenium Ecosystem Assessment (MEA). 2005. Ecosystems and human well-being: synthesis. Island, Washington, D.C., USA.

Mirtl, M., M. Frenzel, E. Furman, C. Ohl, K. Krauze, and C. Grünbühel. 2008. LTER-EUROPE: Criteria and recommendations. Version 5.2, 2008-05-27. LTER-EUROPE. [online] URL: http:// www.lter-europe.net/document-archive/central/I3034v02-LTEREurope-Criteria.pdf
Musche, M., M. Adamescu, P. Angelstam, S. Bacher, J. Bäck, H. L. Buss, C. Duffy, G. Flaim, J. Gaillardet, G. V. Giannakis, P. Haase, L. Halada, W. D. Kissling, L. Lundin, G. Matteucci, H. Meesenburg, D. Monteith, N. P. Nikolaidis, T. Pipan, P. Pyšek, E. C. Rowe, D. B. Roy, A. Sier, U. Tappeiner, M. Vilà, T. White, M. Zobel, and S. Klotz. 2019. Research questions to facilitate the future development of European long-term ecosystem research infrastructures: a horizon scanning exercise. Journal of Environmental Management 250:109479. https://doi.org/10.1016/ j.jenvman.2019.109479

Myrdal, J., and M. Morell. 2011. The agrarian history of Sweden: from 4000 BC to AD 2000. Nordic Academic, Lund, Sweden.

Naumov, V., M. Manton, M. Elbakidze, Z. Rendenieks, J. Priedniek, S. Uhlianets, T. Yamelynets, A. Zhivotov, and P. Angelstam. 2018. How to reconcile wood production and biodiversity conservation? The Pan-European boreal forest history gradient as an "experiment." Journal of Environmental Management 218:1-13. https://doi.org/10.1016/j.jenvman.2018.03.095

Nijnik, M., A. Nijnik, S. Sarkki, J. Muñoz-Rojas, D. Miller, and S. Kopiy. 2018. Is forest related decision-making in European treeline areas socially innovative? A Q-methodology enquiry into the perspectives of international experts. Forest Policy and Economics 92:210-219. https://doi.org/10.1016/j.forpol.2018.01.001

Nijnik, M., and S. Sarkki. 2019. Social innovation for revitalising forest-dependent communities. Chartered Forester Winter 2018/2019:18-19.

Nijnik, M., L. Secco, D. Miller, and M. Melnykovych. 2019. Can social innovation make a difference to forest-dependent communities? Forest Policy and Economics 100:207-213. https:// doi.org/10.1016/j.forpol.2019.01.001

Norgaard, R. B. 2010. Ecosystem services: from eye-opening metaphor to complexity blinder. Ecological Economics 69:1219-1227. https://doi.org/10.1016/j.ecolecon.2009.11.009

Norton, B. G. 2005. Sustainability. A philosophy of adaptive ecosystem management. The University of Chicago Press, Chicago, Illinois, USA.

Nouwens, M., C. Griggio, and W. E. Mackay. 2017. "WhatsApp is for family; Messenger is for friends": communication places in app ecosystems. Pages 727-735 in CHI '17: Proceedings of the 2017 CHI Conference on Human Factors in Computing Systems, Denver, Colorado, USA. https://doi.org/10.1145/3025453.3025484

Organisation for Economic Co-operation and Development (OECD). 2017. New rural policy: linking up for growth. OECD Publications, Paris, France. [online] URL: http://www.fao.org/ family-farming/detail/en/c/522521/

Pallot, J. 1990. Rural depopulation and the restoration of the Russian village under Gorbachev. Soviet Studies 42(4):655-674. https://doi.org/10.1080/09668139008411895

Pascual, U., P. Balvanera, S. Díaz, G. Pataki, E. Roth, M. Stenseke, R.T. Watson, E. B. Dessane, M. Islar, E. Kelemen, et al. 2017. Valuing nature's contributions to people: the IPBES approach. Current Opinion in Environmental Sustainability 26-27:7-16. https://doi.org/10.1016/j.cosust.2016.12.006 
Pinto, B. S., C. Aguar, and M. R. Partidário. 2010. Brief historical ecology of northern Portugal during the Holocene. Environment and History 16(1):3-42. https://doi.org/10.3197/096734010x485283

Poon, P., and C. Wagner. 2001. Critical success factors revisited: success and failure cases of information systems for senior executives. Decision Support Systems 30(4):393-418. https://doi. org/10.1016/S0167-9236(00)00069-5

Potapov, P., M. C. Hansen, L. Laestadius, S. Turubanova, A. Yaroshenko, C. Thies, W. Smith, I. Zhuravleva, A. Komarova, S. Minnemeyer, and E. Esipova. 2017. The last frontiers of wilderness: tracking loss of intact forest landscapes from 2000 to 2013. Science Advances 3(1):e1600821. https://doi.org/10.1126/ sciadv. 1600821

Pretty J. 2003. Social capital and the collective management of resources. Science 302(5652):1912-1914. https://doi.org/10.1126/ science. 1090847

Primdahl, J., L. Søderkvist Kristensen, F. Arler, P. Angelstam, A. Aagaard Christensen, and M. Elbakidze. 2018. Rural landscape governance and expertise: on landscape agents and democracy. Pages 153-164 in S. Egoz, K. Jorgensen, and D. Ruggeri, editors. Defining landscape democracy: a path to spatial justice. Edward Elgar, Cheltenham, UK. https://doi.org/10.4337/9781786438348.00024

Pülzl, H., K. Hogl, D. Kleinschmit, D. Wydra, B. Arts, P. Mayer, M. Palahi, G. Winkel, and B. Wolfslehner. 2013. European forest governance: issues at stake and the way forward. What Science can tell us 2. European Forest Institute, Joensuu, Finland. [online] URL: http://www.efi.int/files/attachments/publications/ efi what science can tell us 2 2013.pdf

Pülzl, H., and M. Lazdinis. 2011. May the open method of coordination be a new instrument for forest policy deliberation in the European Union? Forest Policy and Economics 13:411-418. https://doi.org/10.1016/j.forpol.2011.04.004

Putnam, R. D. 1995. Bowling alone: America's declining social capital. Journal of Democracy 6:65-78. https://doi.org/10.1353/ jod.1995.0002

Putnam, R. D. 2001. Bowling alone: the collapse and revival of American community. Simon and Schuster, New York, New York, USA.

Rametsteiner, E. 2009. Governance concepts and their application in forest policy initiatives from global to local levels. Small-scale Forestry 8:143-158. https://doi.org/10.1007/s11842-009-9078-2

Ray, B., P. Mukherjee, and R. Bhattacharya. 2017. Gender differences in social capital and collective action: does social identity matter in joint forest management? Pages 225-244 in P. Mukhopadhyay, N. Nawn, and K. Das, editors. Global change, ecosystems, sustainability: theory, methods, practice. SAGE Publications India, New Delhi, India. https://doi.

org/10.4135/9789353280284.n18

Rodríguez, J. P., T. D. Beard, Jr., E. M. Bennett, G. S. Cumming, S. Cork, J. Agard, A. P. Dobson, and G. D. Peterson. 2006. Tradeoffs across space, time, and ecosystem services. Ecology and Society 11(1):28. https://doi.org/10.5751/ES-01667-110128
Romanyuk, B. D., A. T. Zagidullina, and A. A. Knize. 2001. Conservation planning in forest management. [Translated from the Russian.] Third edition. WWF, Pskov Model Forest, St Petersburg, Russia.

Rosenfeld, M. J., R. J. Thomas, and S. Hausen. 2019. Disintermediating your friends: how online dating in the United States displaces other ways of meeting. Proceedings of the National Academy of Sciences 116(36):17753-17758. https://doi. org/10.1073/pnas.1908630116

Salemink, K., D. Strijker, and G. Bosworth. 2017. Rural development in the digital age: a systematic literature review on unequal ICT availability, adoption, and use in rural areas. Journal of Rural Studies 54:360-371. https://doi.org/10.1016/i.jrurstud.2015.09.001

Santini, F., S. S. Matus, G. Louwagie, G. Guri, N. Bogdanov, and S. Gomez y Paloma. 2012. Facilitating an area-based development approach in rural regions in the Western Balkans. Publications Office of the European Union, Luxembourg.

Sarkki, S., A. Ficko, K. Grunewald, A. Kyriazopoulos, and M. Nijnik. 2017a. How pragmatism in environmental science and policy can undermine sustainability transformations: the case of marginalized mountain areas under climate and land use change. Sustainability Science 12(4):549-561. https://doi.org/10.1007/ $\underline{\text { s11625-016-0411-3 }}$

Sarkki, S., M. Jokinen, M. Nijnik, L. Zahvoyska, E. Abraham, C. Alados, C. Bellamy, S. Bratanova-Dontcheva, K. Grunewald, J. Kollar, J. Krajčí, A. P. Kyriazopoulos, N. La Porta, A. T. Monteiro, J. Munoz-Rojas, T. Parpan, L. Sing, M. Smith, M.-L. Sutinen, A. Tolvanen, and T. Zhyla. 2017b. Social equity in governance of ecosystem services: synthesis from European treeline areas. Climate Research 73:31-44. https://doi.org/10.3354/ $\underline{\operatorname{cr} 01441}$

Sarkki, S., T. Parpan, M. Melnykovych, L. Zahvoyska, J. Derbal, N. Voloshyna, and M. Nijnik. 2019. Beyond participation! Social innovations facilitating movement from authoritative state to participatory forest governance in Ukraine. Landscape Ecology 34(7):1601-1618. https://doi.org/10.1007/s10980-019-00787-x

Sarvašová, Z., E. Cienciala, J. Beranová, M. Vančo, A. Ficko, and M. Pardos. 2014. Analysis of governance systems applied in multifunctional forest management in selected European mountain regions. Central European Forestry Journal 60 (3):159-167. https://doi.org/10.2478/forj-2014-0017

Sayer, J., T. Sunderland, J. Ghazoul, J. L. Pfund, D. Sheil, E. Meijaard, M. Venter, A. K. Boedhihartono, M. Day, C. Garcia, C. van Oosten, and L. E. Buck. 2013. Ten principles for a landscape approach to reconciling agriculture, conservation, and other competing land uses. Proceedings of the National Academy of Sciences 110(21):8349-8356. https://doi.org/10.1073/pnas. 1210595110

Schafft, K., and D. Brown. 2003. Social capital, social networks, and social power. Social Epistemology 17(4):329-342. https://doi. org/10.1080/0269172032000151795

Selman, P. 2012. Sustainable landscape planning: the reconnection agenda. Routledge, London, UK. https://doi.org/10.4324/9780203119860 
Shackleton, P., P. Angelstam, B. van der Waal, and M. Elbakidze. 2017. Progress made in managing and valuing ecosystem services: a horizon scan of gaps in research, management and governance. Ecosystem Services 27:232-241. https://doi.org/10.1016/j.ecoser.2016.11.020

Shu, K., A. Sliva, S. Wang, J. Tang, and H. Liu. 2017. Fake news detection on social media: a data mining perspective. $A C M$ SIGKDD Explorations Newsletter 19(1):22-36. https://doi. org/10.1145/3137597.3137600

Singh, S. J., H. Haberl, M. Chertow, M. Mirtl, and M. Schmid. 2013. Introduction. Pages 1-26 in S. J. Singh, H. Haberl, M. Chertow, M. Mirtl, and M. Schmid, editors. Long term socioecological research: studies in society-nature interactions across spatial and temporal scales. Springer, Dordrecht, The Netherlands. https://doi.org/10.1007/978-94-007-1177-8 1

Sporrong, U. 1998. Dalecarlia in central Sweden before 1800: a society of social stability and ecological resilience. Pages 67-94 in F. Berkes, C. Folke, and J. Colding, editors. Linking social and ecological systems: management practices and social mechanisms for building resilience. Cambridge University Press, Cambridge, UK.

Špulerová, J., F. Petrovič, P. Mederly, M. Mojses, and Z. Izakovičová. 2018. Contribution of traditional farming to ecosystem services provision: case studies from Slovakia. Land 7 (2):74. https://doi.org/10.3390/land7020074

Stryamets, N., M. Elbakidze, J. Chamberlain., and P. Angelstam. 2020. Governance of non-wood forest products in Russia and Ukraine: institutional rules, stakeholder arrangements, and decision-making processes. Land Use Policy 94:104289. https:// doi.org/10.1016/j.landusepol.2019.104289

Sutherland, W. J., and H. J. Woodroof. 2009. The need for environmental horizon scanning. Trends in Ecology and Evolution 24:523-527. https://doi.org/10.1016/j.tree.2009.04.008

Szreter, S., and M. Woolcock. 2004. Health by association? Social capital, social theory, and the political economy of public health. International Journal of Epidemiology 33(4):650-667. https://doi. org/10.1093/ije/dyh013

Termorshuizen, J. W., and P. Opdam. 2009. Landscape services as a bridge between landscape ecology and sustainable development. Landscape Ecology 24(8):1037-1052. https://doi. org/10.1007/s10980-008-9314-8

Thellbro, C., O. Stjernström, P. Sandström, and G. Lidestav. 2017. Visualizing the forest in a boreal forest landscape - the perspective of Swedish municipal comprehensive planning. Forests 8(6):189. https://doi.org/10.3390/f8060189

Thulin, E., B., Vilhelmson, and T. Schwanen. 2020. Absent friends? Smartphones, mediated presence, and the recoupling of online social contact in everyday life. Annals of the American Association of Geographers 110(1):166-183. https://doi. org/10.1080/24694452.2019.1629868

Turkelboom, F., M. Leone, S. Jacobs, E. Kelemen, M. GarcíaLlorente, F. Baró, M. Termansen, D. N. Barton, P. Berry, E. Stange, M. Thoonen, Á. Kalóczkai, A. Vadineanu, A. J. Castro, B. Czúcz, C. Röckmann, D. Wurbs, D. Odee, E. Preda, E. GomezBaggethun, G. M. Rusch, G. Martínez Pastur, I. Palomo, J. Dick,
J. Casaer, J. van Dijk, J. Priess, J. Langemeyer, J. Mustajoki, L. Kopperoinen, M. J. Baptist, P. L. Peri, R. Mukhopadhyay, R. Aszalós, S. B. Roy, S. Luque, and V. Rusch. 2018. When we cannot have it all: ecosystem services trade-offs in the context of spatial planning. Ecosystem Services 29(C):566-578. https://doi. org/10.1016/j.ecoser.2017.10.011

Van Eupen, M., M. Metzger, M. Pérez-Soba, P. Verburg, A. Van Doorn, and R. Buce. 2012. A rural typology for strategic European policies. Land Use Policy 29(3):473-482. https://doi. org/10.1016/j.landusepol.2011.07.007

Veenstra, G. 2000. Social capital, SES and health: an individuallevel analysis. Social Science \& Medicine 50(5):619-629. https:// doi.org/10.1016/S0277-9536(99)00307-X

Volk, T., M. Rednak, E. Erjavec, E. Zhllima, G. Gjeci, S. Bajramović, Ž. Vaško, D. Ognjenović, J. Butković, M. KerolliMustafa, E. Gjokaj, B. Hoxha, D. Dimitrievski, A. Kotevska, I. J. Stamenkovska, A. Martinovic, D. Konjevic, M. Spahic, N. Bogdanov, R. Papić, S. Todorović, Volk, T., E. Erjavec, P. Ciaian, S. Gomez y Paloma. 2017. Monitoring of agricultural policy developments in the Western Balkan countries. Publications Office of the European Union, Luxembourg.

Wellman, B. 2001. Physical place and cyberplace: the rise of personalized networking. International Journal of Urban and Regional Research 25(2):227-252. https://doi.org/10.1111/1468-2427.00309

Welzl, C. 2013. Freedom rising. Human empowerment and the quest for emancipation. Cambridge University Press, Cambridge, UK. https://doi.org/10.1017/CBO9781139540919

White, H. C. 2008. Identity and control: how social formations emerge. Princeton University Press, Princeton, New Jersey, USA. https://doi.org/10.1515/9781400845903

Winter, S. 2012. Forest naturalness assessment as a component of biodiversity monitoring and conservation management. Forestry 85(2):293-304. https://doi.org/10.1093/forestry/cps004

World Heritage Centre/IUCN. 2018. Report of the joint WHCl IUCN Reactive Monitoring mission to Bialowieza Forest (Belarus/ Poland), 24 September to 2 October 2018. UNESCO, Paris, France. [online] URL: https://whc.unesco.org/en/documents/172879/

Worster, D. 2005. Doing environmental history. Pages 2-9 in C. Merchant, editor. Major problems in American environmental history. Houghton Mifflin, Boston, Massachusetts, USA. 


\section{Appendix 1.}

\section{Narratives about 16 case study regions and "hotspot" landscapes}
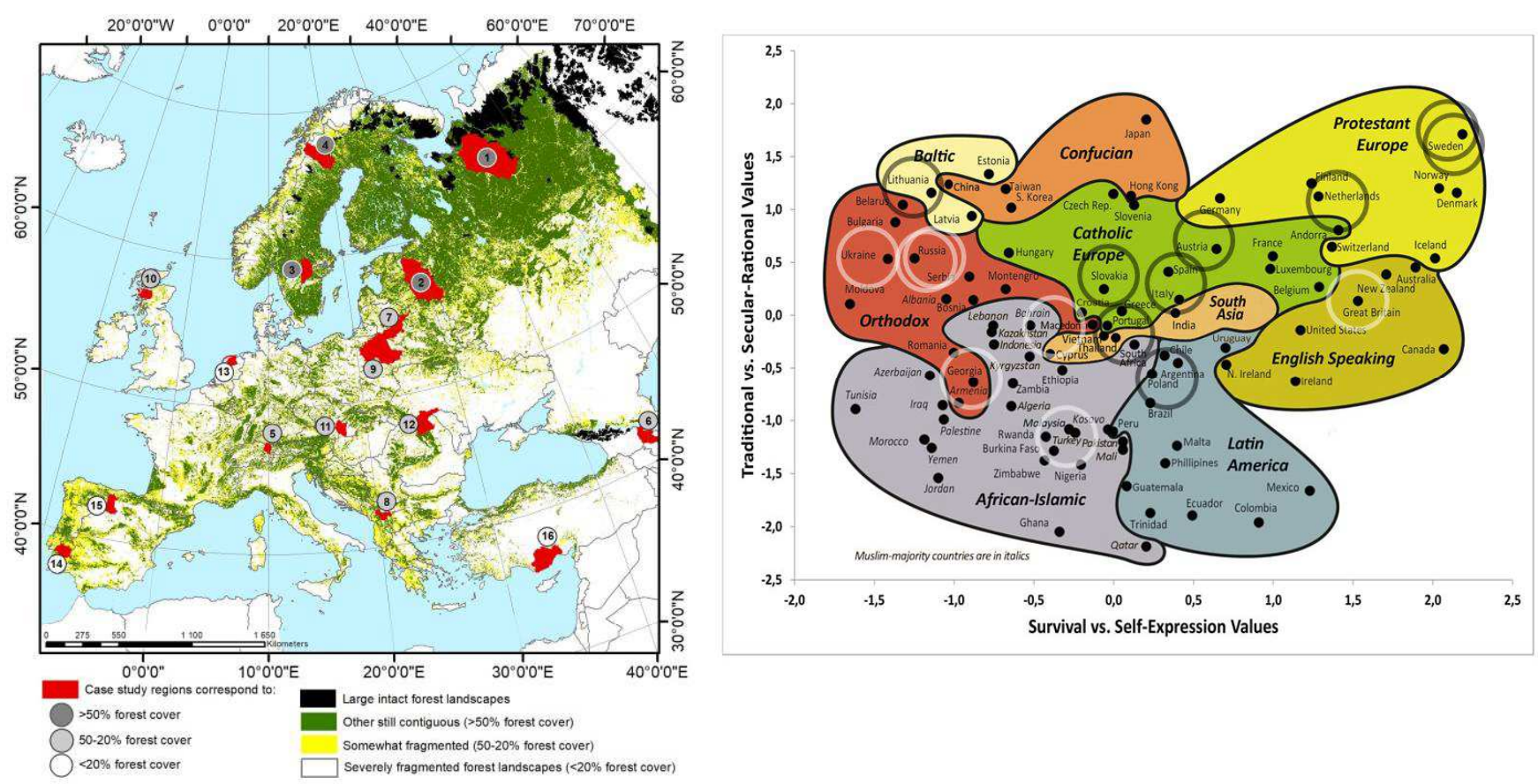

Location of 16 case study regions (in red) on the European continent, and with a "hotspot" landscape inside each of them.

Location of 16 case study regions and "hotspot" landscapes in EU (darker circles) and non-EU (lighter circles) countries on the Inglehart-Welzel Cultural Map.

Russia: NE Arkhangelsk region, Pinega-Dvina intact forest landscape 4

Summary of case study region and hotspot landscape

Traditional fora

New fora

Virtual fora

Summary related to social capital framework

Literature cited

Russia: Pskov oblast, Strugi Krasnye municipality

Summary of case study region and hotspot landscape

Traditional fora

New fora

Virtual fora

Summary related to social capital framework

Literature cited

Poland and Belarus: Narew catchment, Bialowieza forest

Summary of case study region and hotspot landscape

Traditional fora

New fora

Virtual fora 
Summary related to social capital framework

Literature cited 17

Lithuania: Dzūkija region, Dzūkija National Park __ 19

Summary of case study region and hotspot landscape __ 19

Traditional fora — 20

New fora__ 20

Virtual fora__ 21

Summary related to social capital framework __ 21

Literature cited — 21

Sweden N: Jokkmokk municipality, Änok/Kvikkjokk___ 23

Summary of case study region and hotspot landscape __ 23

Traditional fora _ 24

New fora__ 24

Virtual fora 25

Summary related to social capital framework _ 25

Literature cited — 25

Sweden S: Örebro County, Tiveden __ 27

Summary of case study region and hotspot landscape __ 27

Traditional fora __ 28

New fora__ 28

Virtual fora__ 28

Summary related to social capital framework __ 29

Literature cited _ 29

Austria: Vorarlberg, Montafon __ 30

Summary of case study region and hotspot landscape __ 30

Traditional fora _ 31

New fora__ 32

Virtual fora__ 32

Summary related to social capital framework __ 32

Literature cited _ 32

Ukraine/Romania: Bukovyna region, Putyla district ___ 34

Summary of case study region and hotspot landscape __ 34

Traditional fora _ 35

New fora__ 35

Virtual fora__ 36

Summary related to social capital framework __ 36

Literature cited — 36

Georgia: Kakheti region, Tusheti province in Akhmeta municipality ___ 38

Summary of case study region and hotspot landscape ___ 38

Traditional fora ___ 39

New fora___ 40

Virtual fora__ 40

Summary related to social capital framework __ 40

Literature cited _— 41

Turkey: Mersin and Karaman provinces, Gülnar oak woodland ___ 43

Summary of case study region and hotspot landscape __ 43

Traditional fora —u 44

New fora__ 44

Virtual fora__ 45

Summary related to social capital framework __ 45 
Sharra Mountain Region (North Macedonia, Kosovo, Albania) __ 47

Summary of case study region and hotspot landscape ___ 47

Traditional fora _— 48

New fora__ 48

Virtual fora__ 49

Summary related to social capital framework _ 49

Literature cited — 49

Slovakia: Bratislava and Trnava regions, Trnava __ 51

Summary of case study region and hotspot landscape __ 51

Traditional fora — 52

New fora__ 52

Virtual fora__ 53

Summary related to social capital framework _ 53

Literature cited — 53

Portugal: Èvora/Alentejo central region, "Sitio de Monfurado"

Summary of case study region and hotspot landscape __ 55

Traditional fora — 56

New fora__ 56

Virtual fora__ 57

Summary related to social capital framework __ 57

Literature cited _ 57

Spain: Palencia province, Palencia Model Forest___ $\mathbf{5 8}$

Summary of case study region and hotspot landscape __ 58

Traditional fora _ 59

New fora__ 59

Virtual fora__ 59

Summary related to social capital framework _ 60

Literature cited — 60

The Netherlands: Fryslân (Friesland), Beetsterzwaag ___ 61

Summary of case study region and hotspot landscape __ 61

Traditional fora — 62

New fora__ 62

Virtual fora_ 63

Summary related to social capital framework __ 63

Literature cited — 63

Scotland: Lochaber region, Sunart __ 65

Summary of case study region and hotspot landscape __ 65

Traditional fora __ 66

New fora__ 66

Virtual fora__ 67

Summary related to social capital framework __ 67

Literature cited _ 67 


\section{Russia: NE Arkhangelsk region, Pinega-Dvina intact forest landscape}

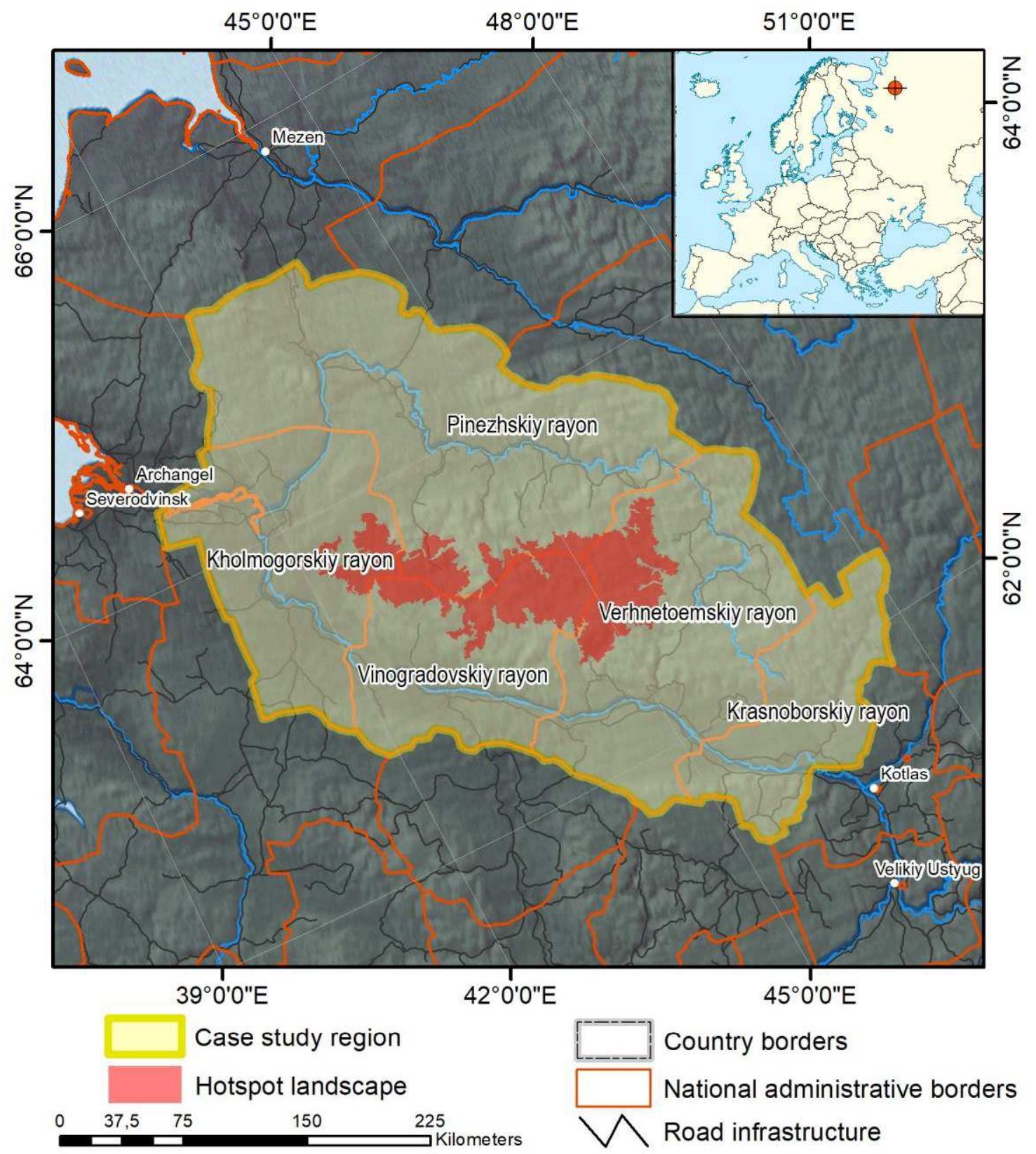

Summary of case study region and hotspot landscape

The history of significant human influence on forests began in the 15th century, when forests were impacted by selective logging for spars, firewood, production of tar, potash, and salt and later for large diameter trees to supply Peter the Great's shipbuilding (Dekatov 1961, Redko and Babich 1993, Sokolov 2006). Cuttings were made in winter with cross-cut saw and a horse skidding. Slash and burn agriculture was applied mostly around settlements until the early 20th century (Kozubov and Taskaev 2000). There have been conservation efforts in Russia since the beginning of forest use. In 1703 Peter the Great protected forests along rivers used for wood rafting. The first protected areas ('корабельные рощи' = 'mast-tree groves') were established in this period to conserve pine and larch timber for shipbuilding (Redko and Babitch 1993, Naumov et al. 2017). During 1730-1750 the first forest inventory 
was carried out, and the $19^{\text {th }}$ century gradually brought industrial logging with international companies. Since the 1840s forest inventory and forest management rules were centralized and oriented towards profitable forest management based on selective fellings. In the 1890s, on a state level, all forests were divided into "commercial" and "protective", i.e., protecting natural and cultural heritage. However, in the 1930s Soviet forestry was re-oriented to "wood mining" (Knize and Romaniouk 2006). In the 1930s to 1950 s forced-labour so called GULAG camps for convicts (спецпереселенцы) were made available for the purposes of local state forestry enterprises. Up to 1960-1980s forestry was mostly focused on high quality pine and larch wood. Good salaries encouraged migration to the Russian North where forest villages were built for the purposes of local state forestry enterprises. These were in operation until the late 1980s, when they were gradually closed due to lack of economically accessible timber, and to the ban on wood rafting on rivers (молевой сплав). Forest harvest rates thus declined sharply; in the entire Arkhangelsk from ca. 30 to 10 million $\mathrm{m}^{3} / \mathrm{yr}$ at the end vs. after the Soviet period in 1991 (e.g., Pashkevich 2003).

The Northern Dvina and constituent Pinega river catchments are located on the vast Russian plain in NW Russia. The geography of this region (severe climate, coniferous taiga, high density of rivers and wetlands) has limited the human population density throughout history. Nomadic groups visited the most productive areas for hunting, fishing, and followed herds of wild reindeer (Karmanov 2012). In the $4^{\text {th }}$ to $7^{\text {th }}$ centuries Finno-Ugric tribes began to colonize the area, partially replacing hunting, fishing and gathering by animal husbandry, agriculture and local forest use. In the north, hunting and fishing were partially substituted by reindeer husbandry (Konakov 2004). The expansion of Novgorod Russia began in the $7^{\text {th }}$ century with trade of furbearers in exchange for bread. Following the Batu mongol invasion in the $8^{\text {th }}$ century (Platonov 1923) a large number of settlements were founded on the banks of rivers, which was the only transport infrastructure (Makarov 1998). In the $15^{\text {th }}$ century, after Moscow Russian occupation, Novgorodians and aboriginal population became state peasants (Shoulatikova, 2003). Since the time of Moscow-led Russia, economic and cultural contacts between regions as well as state taxation have increased. Furs were exchanged for salt, bread, flax, hemp and iron at city fairs, and furs were used to pay federal level taxes. This caused declining numbers of hunted species and the fall in profit margin of hunting and fishing already in 17th century (Konakov 1983) and was one of the reasons for emigrations to Siberia. The region's remoteness of Northern Dvina and Pinega was a foundation of settlements providing asylum for old believers (старове́ры), who maintain practices of the Eastern Orthodox Church after they were anathematized in 1666-67. Having no episcopal hierarchy, they renounced priests and all sacraments. In the 17th to 19th centuries old believers have been repeatedly targeted because of their religious practice (Shipin, 2003). In the post-Soviet period the population decreased due to emigration to the central cities.

The Arkhangelsk region hosts 14 intact forest landscapes (i.e. exceeding $500 \mathrm{~km}^{2}$; see Potapov et al. 2017) covering $15 \%$ of the region (WWF Russia, 2016). One of the largest and most valuable intact forest landscapes is located between the Northern Dvina and Pinega rivers. At present, the population density in the Dvina-Pinega hotspot landscape is about 1 person per $\mathrm{km}^{2}$ (Anon. 2019), but people are concentrated to a few larger villages on river banks, located $>50 \mathrm{~km}$ from the Dvina-Pinega intact forest landscape itself. In the mid-2000s, only a small area of intact forest landscapes was protected in the region (Stolpovskiy and Dobrynin, 2010). Most of their areas were leased to several forestry companies for wood harvesting. From 2001 to 2018, the Arkhangelsk region lost about 5.9\% of the intact forests. However, on the other hand in the period 2013-2019, three state protected areas (1 national park and 2 nature reserves) were created in the region to conserve intact forest landscapes. The intact forest landscape on the watershed between the Pinega and Northern Dvina rivers exhibits high diversity of natural ecosystems and can be viewed as a representative example of naturally dynamic 
European middle and northern boreal forest, and a hotspot for intact forest landscape conservation. The area hosts one of the last southern populations of red-listed wild forest reindeer (Rangifer tarandus), and many other vulnerable forest species. These forests are crucial to the preservation of spawning streams for salmon (Salmo salar) and play an important role in climate regulation, water and carbon balance (Zagidullina et al. 2013). As a result of an expanding logging frontier, the area of the DvinaPinega intact forest landscape (Zhuravlyova et al. 2006, Zagidullina 2009, Zagidullina et al. 2013, Voronin et al. 2019) has shrunk from $11460 \mathrm{~km}^{2}$ in 2000 to $7705 \mathrm{~km}^{2}$ in 2017 (Karpov 2019, Khakimullina 2019. Continued logging also destroys the possibilities of traditional forest use for local people (i.e. inherited hunting areas).

\section{Traditional fora}

Historically, hunting, fishing and farming form the base for rural livelihoods. Youth people and men also spent significant time at seasonal work (отхожие промыслы). Traditionally, self-governing communities of local peasants elected their own heads, and carried out the allocation of local forests, fisheries, hunting grounds, hayfields, and supported orphans. Both old believers and official Orthodoxy co-existed in villages. High ethical standards of old believers (refusal of alcohol, need to keep your word etc.) facilitated self-governing, and also successful business development in 19th and beginning of 20 th centuries. At the beginning of the 20th century missionary societies on the basis of church parish were developed. The establishment of the zemstvo system in 1864 for local government, which was set up after the abandonment of serfdom in 1861, restored local self-government to Russia (in the northern part of area this system was established only in 1917). The significance of zemstvo is not only in the development of the social and economic environment (universal schools, summer kindergardens and clinics), but also the formation of self-government by zemstvo deputies and interaction on the basis of electivity. The zemstvo program to establish small units of self-government was a key element of civil society (Usitalo and Whisenhunt 2008). The Bolshevik revolution in 1917 and collectivisation of agriculture in 1929 destroyed these systems. However, peasants had the right to vote in the collective farms (колхоз), but did not have passports and could not leave the farm without the head's consent. Since the 1950s many small settlement were abandoned, and people were resettled to a few larger villages. In the 1960s, instead of collective farms, state farms (mostly meat and dairy) without selfgovernment were organized. These farms were operated up to the end of the Soviet period in 1991.

\section{New fora}

In post-Soviet time the strong exhaustion of profitable forest resources, lack of work places, closure of schools, hospitals, lack of transport infrastructure (collapse of boat and airplane connections) caused emigration from remote regions. Those who have working places (teachers, doctors, forestry service and retirees) stay in the villages. Many people are engaged in hunting, fishing, picking berries and mushrooms (e.g., Stryamets et al. 2015, Voronin et al. 2019). Only some small farms were established on the basis of state farm remains. The male population mostly work in away ( oil and gas field (Northern Komi, Western Siberia etc.). People nevertheless spend their free time in forest and villages. During the period of economic growth (2000-2013), state monetary support (via the re-distribution of oil and gas rents) was the only way to solve the social problems. After oil prices fell in 2014 the state social support was dramatically reduced. Additionally, there are conflicts over natural resource management, a lack of strategy, as well as insufficient communication among sectors as well as between local communities and authorities is. In response to this local communities discuss threats and opportunities for local development, arrange social events and meetings. Non-governmental environmental organizations and research institutes have proposed preserving part of the area by assigning it a status of a regional landscape reserve and implement landscape ecological planning of the remaining area (Zagidullina et al. 2009, 2013). Here, FSC certification as a "non-state market-driven 
governance system" (Cashore 2002: 503) or a "governance generating network" (Tysiachniouk and McDermott 2015: 2) can be considered as an example of new fora. FSC creates platforms for negotiation and collaboration between environmental NGOs and private timber companies towards trade-offs on the conservation of intact forests and the development of sustainable forest management. Thus, the Dvinsko-Pinezhsky nature reserve (just over $3,000 \mathrm{~km}^{2}$ ) covering about one-third of this intact forest landscape was created in 2019 by the regional government on the basis of 'harvesting moratoria zones' - non-legally binding logging ban agreements between forest leaseholders and environmental NGOs within the framework of the FSC certification. In the context of integration of FPIC (Free Prior Informed Consent) into the FSC forest management standards, forest certification can be considered also as a new forum to achieve mutual consent around forest management issues between local communities and timber companies (Dobrynin et al. 2020).

\section{Virtual fora}

Mobile internet coverage has increased significantly in recent years. Now almost every village has own internet page for news and communication. Virtual methods are used for debates for local community. Regarding the remoteness of region, access to internet has been used to connect different levels of governance. Social media allow quick spread of information among people, and facilitate the formation of civil associations to address specific issues. Virtual fora can show that social and environmental challenges are not local, but need to be addressed at regional and Federal levels. On illustrative example is the protest against forest clearing for dumping Moscow garbage near the Shiyes (Шиес) railway station in Arkhangelsk (https://www.youtube.com/watch? $\mathrm{v}=\mathrm{sq} 2 \mathrm{TLVsrGg8}$ and https://www.youtube.com/watch? $\mathrm{v}=8 \mathrm{cL} 8 \mathrm{a} 1 \mathrm{gVdjo})$. An example of virtual fora is WEB-GIS service "hcvf.ru" designed for technical assistance and spatial data exchange in the process of negotiations between NGOs and timber companies on protection of high conservation value forests under the FSC certification processes.

\section{Summary related to social capital framework}

In the Archangelsk region rural labour mobility is limited due to long distances and poor transport infrastructure. Accessibility of social services (schools, health service etc.) is low due to their sharp reduction and remoteness. The emigration from the rural areas causes difficulties in maintaining all social capital forms. The implementation of intensive forestry into secondary forest lands (Romaniouk et al. 2013) could substitute extensive logging of old-growth forest massifs and increase employment of local people. Besides, forestry companies (i.e. FSC certified) and auditors should increase accessibility of public information and questioning about their management and construction activity. Well preserved natural (intact forest landscapes) and cultural heritage (settlements with unique buildings along rivers) (Davydov and Efimov 2009, Shulatikova 2011) provide good options for the development of tourism. High ethical standards inherited from old believers, provide trusting relations between local people and friendly environment. Local rural populations now maintain a high level of intercommunity mutualism and trust, because these are necessary conditions to survive in remote rural areas. It is a good foundation for the development of civil institutions and human well-being outcomes. However, these outcomes are strongly restricted by failed management on regional and federal levels. The main institutional problems are 1) extremely low credibility of public authority institutions 2) lack of real self-government at the local level 3) insufficient communication between authorities and local populations. To solve the economic problems rural development is urgent (Zubarevitch, 2017). Three examples are: to decrease institutional barriers for the farms and personal household development, expand mobile forms of social services (especially health) and increase support for poor families with children. To strengthen social capital there is therefore a need to strengthen the decentralization process and undertake deep institutional reforms (e.g., re-establishment of zemstvos). 


\section{Literature cited}

Anon. 2019. Arkhangelsk region in figures. Concise statistical yearbook. Official publication. 263 p.

Cashore, B. 2002. Legitimacy and the privatization of environmental governance: how non-state market-driven (NSMD) governance systems gain rule-making authority. Governance 15 (4), 503529.

Davydov, A.N., and V.A. Efimov. 2009. About protection of natural and cultural heritage in the territory between Severnaya Dvina and Pinega rivers (Archangel Oblast). In: Spidso, T.K., Sorensen, O.J. (eds.) The last large intact forests in Northwest Russia. Protection and use. TemaNord 53: 37-43.

Dobrynin, D., E. Smirennikova, and I. Mustalahti. 2020. Non-state forest governance and 'Responsibilization': The prospects for FPIC under FSC certification in Northwest Russia. Forest Policy and Economics 115, 102142.

Dobrynin, D., and A. Stolpovsky. 2010. Landscape diversity and system of protected areas of the Archangelsk Oblast. WWF. Moscow.

Efimov, V. A. 2009. Preservation of the last large intact forests and biodiversity of the Archangelsk Oblast in Russia, an important task in international cooperation. In: Spidso, T.K., Sorensen, O.J. (eds.) The last large intact forests in Northwest Russia. Protection and use. TemaNord 53: 45-50.

Karmanov, V. 2012 Neolithic population on European North-East: the primeval antiquities of Eurasia. Institute of Archaeology, Russian Academy of Sciences, Moscow, IA RSA p. 419-446.

Karpov, A.A. 2019. Area reduction of intact forest landscapes on the example of the Dvina-Pinega interfluve. Lesnoy Zhurnal [Forestry Journal] 3: 152-158. (in Russian)

Khakimullina, T. 2019. Over two decades of campaigning results in new protected area for the pearl of Russia's Northern European forests - Dvinsky forest. http://forestforum.ru/viewtopic.php?f=28\&t=23824, https://youtu.be/SGenVzxWvs8.

Knize, A., and B. Romanyuk. 2006. Two opinions of Russia's forest and forestry. WWF Russian Programme Office, Moscow.

Knize A, and Romaniouk B. 2012. The causes of unprofitable forestry in Russia. Proceedings of SaintPetersburg Forestry Research Institute 1-2: 3-7.

Konakov, N.D. (Ed.) 2004. Zyryan's world: essays on the traditional culture of Komi. Komi publishers. Syktyvkar. 472 p. (in Russian)

Makarov, N. 1998. The northern periphery of Russia 1000-1300 AD: colonization, settlement patterns, economical changes. Outland Use in Preindustrial Europe. Lund Studies in Medieval Archaeology 20:40-50.

Naumov, V., P. Angelstam, and M. Elbakidze. 2017. Satisfying rival objectives in forestry in the Komi Republic: Effects of Russian zoning policy change on forestry intensification and riparian forest conservation. Canadian Journal of Forest Research 47: 1339-1349.

Pashkevich, A. 2003. Development of the forest sector in the Arkhangelsk oblast during the transition period of the 1990s. Fennia 181(1):13-24.

Platonov, S. 1923. History of Russian North. Essays on colonization of the White See region. "Vremya".

Potapov, P., M. C., Hansen, L. Laestadius, S. Turubanova, A. Yaroshenko, C. Thies, ... and E. Esipova. 2017. The last frontiers of wilderness: Tracking loss of intact forest landscapes from 2000 to 2013. Science advances, 3(1), e1600821.

Redko G., and N. Babich 1993. Mast-tree groves for Russian navy's glory. Archangelsk Forestry Academy, North-Western Publishers, Archangelsk. 151 p.

Shoulatikova, E. 2011. Results of settlements survey in the middle reaches of the Pinega River. The modern state of residential and manor buildings of the XVIII - XX centuries // Novgorod and Novgorod land. Art and Restoration Novgorod 5: 170 - 184. 
Stryamets, N., M., Elbakidze, M., Ceuterick, P. Angelstam, and R. Axelsson. 2015. From economic survival to recreation: contemporary uses of wild food and medicine in rural Sweden, Ukraine and NW Russia. Journal of Ethnobiology and Ethnomedicine 11:53.

Tysiachniouk, M., and C. L. McDermott. 2016. Certification with Russian characteristics: Implications for social and environmental equity. Forest Policy and Economics 62:43-53.

Voronin, V.V., S.V., Tretyakov, and A.P. Bogdanov. 2019. Assessment of anthropogenic impact on hardly-accessed forests between northern Dvina and Pinega rivers.// Science for northern forestry. Demidova N. (Ed.) pp. 127-133 (retrieved at http://www.sevniilharh.ru/publications/\%D1\%81\%D0\%B1\%D0\%BE\%D1\%80\%D0\%BD\%D0\%B8\%D0\%BA_\%D0\% A1\%D0\%B5\%D0\%B2\%D0\%9D\%D0\%98\%D0\%98\%D0\%9B\%D0\%A5 2019.pdf)

WWF Russia. 2016. Intact forest landscapes in Russia: current condition and losses over the last 13 years / Poster, A1. Moscow, World Wildlife Fund (WWF Russia), 2016

Zagidullina, A. 2009. Vegetation of Intact Forest Landscape on the watershed between Northern Dvina and Pinega rivers. In: Kauhanen H., Neshataev V., Huhta E., Vuopio M. (Eds.) Northern Coniferous Forests -Tools through Research for the ecologically based forestry. Kupijuva, Jyväskylä. p. 90-107.

Zagidullina A., and V. Kotkova (Eds.) 2013. Landscape and biological diversity of the watershed between the Northern Dvina and Pinega rivers. WWF, Saint-Petersburg. 2013. 116 p.

Zhuravlyova, I., A. Zagidullina, D., Lugovaya, and T. Yanitskaya. 2007.High conservation forests monitoring in intact forest areas between Sev. Dvina and Pinega as an example. (http://eprints.tversu.ru/273/1/Zhuravlyova_dr.pdf)

Zubarevitch, N.V. 2017. Rural development in Russia: social and gender issues. International Agricultural Journal 2: 12-14. (In Russian)

Usitalo S., and W. Whisenhunt (Eds.) 2008. Russian and Soviet History: From the Time of Troubles to the Collapse of the Soviet Union Lanham, Boulder, New York, Toronto, Plymouth, UK: Rowman \& Littlefield Publishers, 


\section{Russia: Pskov oblast, Strugi Krasnye municipality}

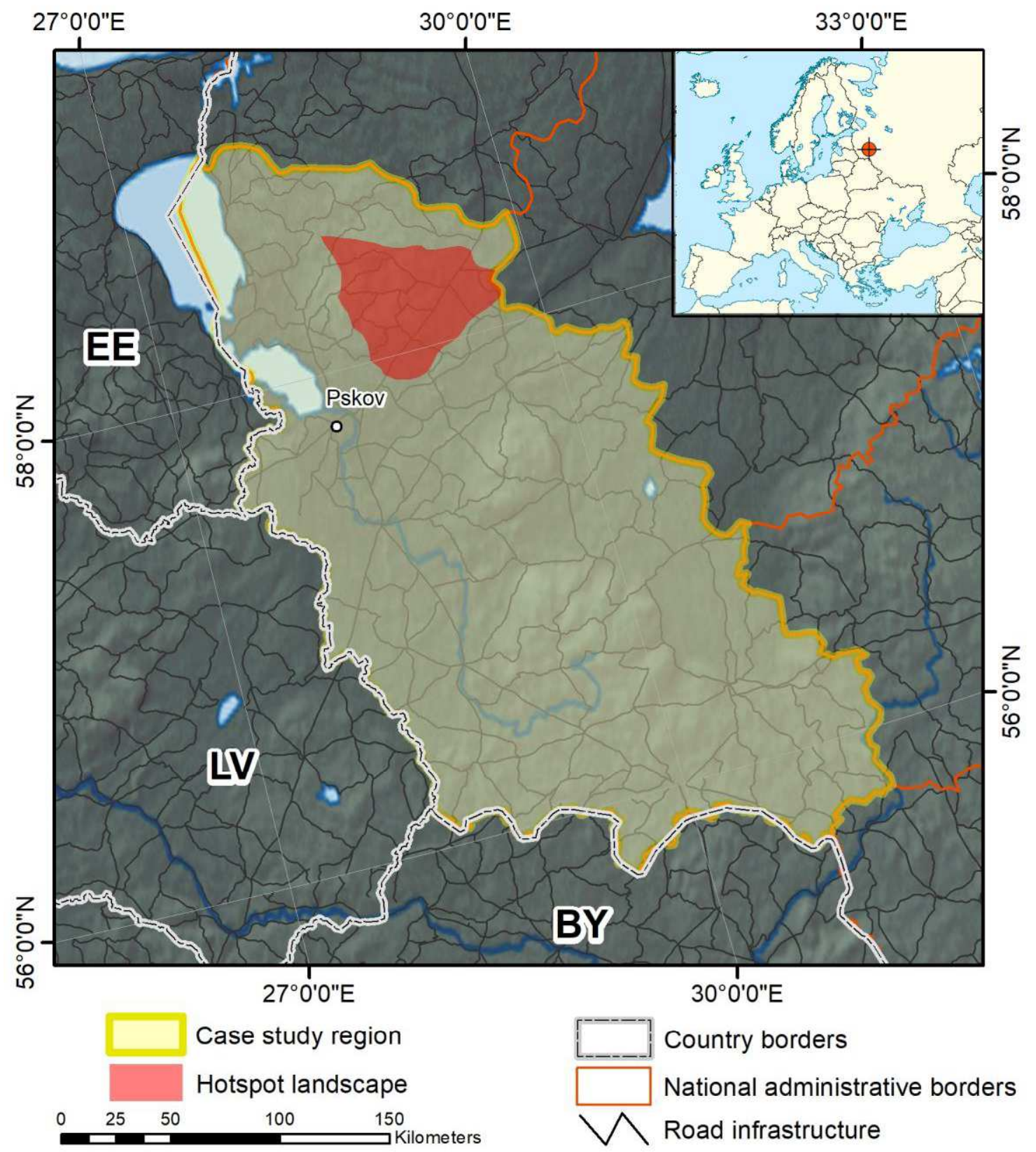

Summary of case study region and hotspot landscape

According to the Pskov $3^{\text {rd }}$ chronicle (Savignac 2016) the city Pskov existed already before $862 \mathrm{AD}$ when Rurik settled in Novgorod. In 903 Pskov was mentioned as a town state and fortress with a strategic location for trade and transport. Forests were gradually cut and burned to gain farmland and meadows. The cultural region Setu reflects this, and is divided between Russia and Estonia (Palang et al. 2006). Under widespread feudalism peasants could be bought, sold or traded together with land (serfdom). The cessation of serfdom in 1861 gradually led to more intensive forest use for local markets. Prior to World War 1 the "farmer and land bank" system, through which new free farmers acquired land and paid by logging, led to increasingly selective forest harvesting. After the Russian 
Bolshevik revolution in 1917 and mostly after 1929, when state forestry enterprises where established, forests were cut intensively without regulations, generally concentrated to easily accessible parts. By around 1935 all mature forest stands ready for final-felling and older had been cut. During World War 2 the forestry activity declined and harvesting was restricted to the vicinity of roads, but after World War 2 mechanised commercial forestry commenced. In the 1950s central heating became popular in the urban areas and villages, which reduced logging considerably and favoured an increased amount of deciduous trees in harvested areas. Reforestation after harvesting started only in the 1960s. After collapse of the USSR during the latter half of the 1990s commercial harvesting increased again (see Angelstam and Dönz-Breuss 2004). Among the NW regions of Russia, Pskov oblast has the lowest gross industrial round wood demand of the forest-dominated regions, and highest unreported production of industrial round wood (Gerasimov, Karjalainen 2006). The transition process after the end of the USSR is characterized by an increasing urban-rural split (Roll et al. 2001). The population on the countryside dwindled, fields and meadows were gradually abandoned, resulting in a drop in wheat harvest in Pskov of 94\% from 1990 to 2010 (Saraykin et al. 2017:158). This is consistent with the general re-emergence in NW Russia of "archipelagos of quasi-von Thunian isolated states, with fast expanding forest tracts in the outer part of every region" (Ioffe and Nefedova 2004).

Strugi Krasnye district is located in NW Russia's westernmost oblast Pskov. The state is the only forest owner. Nineteen percent of this district is used as a military training area (Anonymous 2018). Intensive logging during the $20^{\text {th }}$ century without subsequent silviculture led to a domination of young- and middle-aged stands with a mix of deciduous trees (birch and aspen) and conifers (pine and spruce) (Angelstam and Dönz-Breuss 2004, Angelstam et al. 2018). Wood export and local wood processing are the main economic activities. The municipality is supporting maintenance of rural areas, cultural heritage and tourism development (Elbakidze et al. 2018). From 2000 to 2008 this case study area hosted the Pskov Model Forest, which aimed to develop new regional forestry norms for intensification of forest management to sustain the wood resource base, primarily for international forest companies using the Nordic intensive sustained yield approach (Elbakidze et al. 2010).

\section{Traditional fora}

Until the end of the 18th century Strugi Krasnye belonged to the Novgorod province, but was then relocated to the Saint-Petersburg province until 1945. Farming and agriculture formed the base for rural livelihoods, and agricultural technologies for long reflected feudal forms of land ownership and serfdom. Wet climate, low fertility of soils and agrarian overpopulation in the 19th century led to shortage of arable land and hay meadows. The proximity to Saint-Petersburg led to jobs in the capital, and allowed peasants to engage in fishing (mostly in the nearby Peipsi lake), flax processing, woodwork, forestry for firewood, charcoal and tar, hunting, berries harvesting (Сушков \& Брулева 2006). Capitalist modernization of the agrarian economy began with the emancipation of the serfs in the 1860s. Some of the landlords managed to create large model capitalist farms on their estates. Peasants gained control of about half of the land they had previously cultivated as serfs, and began to ask for the redistribution of all land. Many Estonians farmers then acquired land in Strugi Krasnye, and at the time their share of the population was 10-30\%. The establishment of the zemstvos in 1864 increased local self-government. The Stolypin agrarian reform, which aimed at coping with the transition from feudalism to capitalist-oriented private ownership farmsteads (Leonard 2010, Pallot 1999), additionally improved the class of landowners. As a result, in the 1920s much progress had been made in farm development. After the Bolshevik revolution in 1917 zemstvos where denounced and substituted by village councils. The collectivisation of agriculture in 1929 destroyed the traditional governance system. Even if peasants had the formal right to vote in the collective farms (колхоз), they did not have passports and could not leave the farm without the head's consent. A high proportion of 
peasants was classified as well-off kulaks, and subsequently suffered from Stalinist repression in the 1930s. As a result of repression, the population of Strugi Krasnye district declined from 72,000 in 1917 to 37,000 before World War 2. Since the 1950s many small settlement were abandoned, and their populations were resettled to some larger villages. In the $1960 \mathrm{~s}$, state farms were organized. These farms were operated up to the end of the Soviet period in 1991. After the 1990s Strugi Krasnye belongs to the group of districts with the lowest rating of the socio-economic situation in Russia. The agricultural sector is severely degraded, and dairy plants are closed. Accessibility of social services (schools, health service etc.) is low due to their drastic reduction in recent years. During the past 30 years the population of Strugi Krasnye district declined from 16000 to 10000 . Villagers are mainly elderly retired people, who use traditional fora with limited social interactions with the outer world.

\section{New fora}

Large forest industry companies in Sweden and Finland, which were using Russian timber and pulpwood, experienced problems with a reduced supply starting in the early 1990s after the collapse of the Soviet Union. In the 1990s, the Pskov region began to play an important role in the Baltic timber trade. However, the Nordic approach to intensification contradicted the existing Russian system of forestry norms and regulations. To improve economic efficiency, the forest leaser StoraEnso Co. initiated a project targeted at sustaining profits from timber industry on a long-term basis (Elbakidze et al. 2010). At that time, harvesting operations by western companies in Russia aroused serious protests among the local population.

The Pskov Model Forest (Yablochkina et al. 2007) was a development and demonstration project, which appeared as a result of simultaneous interests of foreign donors for development of approaches to sustainable forest management in Russia, and the presence of local and regional champions able to act as brokers. This made it possible to promote and implement demonstration sites aimed at intensifying forest management by tree planting and pre-commercial and commercial thinning (Knize and Romanyuk 2006; Romanyuk et al. 2005), and forest planning based on landscape approach (Romanyuk et al. 200; Zagidullina et al. 2012). The majority of the activities were initiated, facilitated and financed by foreign donors. The Pskov Model Forest operated in a specific governance domain on a national level, which enhanced the ability to develop adaptive capacities in the local Model Forest initiative. Stakeholders in Pskov Model Forest initiative began to develop a network-based type of governance system both locally and regionally, and the dissemination of project experiences is currently in progress. Due to the Model Forest's activities, partnership among local and regional stakeholders has emerged that still exist in different constellations (Elbakidze et al. 2010). However, scaling-up is hampered by a fragmented governance system in Russia with poorly functioning institutions and corruption (e.g., Naumov et al. 2016; Angelstam et al. 2017). Cultural, political and language barriers currently hinder learning based on comparisons of what portfolios of ecosystem services that different approaches to forest management deliver.

\section{Virtual fora}

Mobile internet coverage in Strugi Krasnye has increased significantly in recent years. Now almost every village has own web page for news and communication (mostly using ВКонтакте (vk.com)). Virtual means are used for debates in local communities. To cope with the remoteness of region, access to internet has been used to connect different levels of governance (f.e.gosuslugi.ru). Social media allows the quick spread of information among people, and facilitate the formation of civil associations to address specific issues. Virtual fora can enhance the ability to address social and forest challenges. 


\section{Summary related to social capital framework}

Both during the crisis of the 1990 s and during recovery from it, there is an increasing economic polarization of Russia's rural areas (Nefedova 2011). Problems include outdated system of economy and mismanagement, sociodemographic change, destruction of the archaic order of life, lack of social environment in the periphery, which is needed to retain young people. The emigration causes difficulties in maintaining all forms of social capital. To generate positive changes urgent actions are needed, e.g., decrease institutional barriers for farms and other small private business, expand mobile forms of social services (especially health) and increase support for poor families with children (Zubarevitch 2017). The development of participatory democracy and self-governance can empower citizens and enhance social capital

\section{Literature cited}

Anonymous. 2018. Forest plan of Pskov oblast. Pskov: Sevzaplesproekt.

Angelstam, P., and M. Dönz-Breuss. 2004. Measuring forest biodiversity at the stand scale: An evaluation of indicators in European forest history gradients. Ecological Bulletins 51, 305-332.

Angelstam, P., V. Naumov, and M. Elbakidze. 2017. Transitioning from Soviet wood mining to sustainable forest management by intensification: Are tree growth rates different in northwest Russia and Sweden? Forestry 90 (2), 292-303.

Angelstam, P., V. Naumov, M. Elbakidze, M. Manton, J. Priednieks, and Z. Rendenieks. 2018. Wood production and biodiversity conservation are rival forestry objectives in Europe's Baltic Sea Region. Ecosphere 9(3), Article e02119.

Elbakidze, M., P. Angelstam, L. Dawson, A. Shushkova, V. Naumov, Z. Rendenieks, L. Liepa, L. Trasūne, U. Ustsin, N. Yurhenson, S. Uhlianets, M. Manton, A. Irbe, M. Yermokhin, A. Grebenzshikova, A. Zhivotov, and M. Nestsiarenka. 2018. Towards functional green infrastructure in the Baltic Sea Region: Knowledge production and learning across borders. In: Ajith Perera, Urmas Peterson, Guillermo Pastur and Louis Iverson (eds.). Ecosystem Services from Forest Landscapes: Broadscale Considerations. Springer. pp. 57-87. https://doi.org/10.1007/978-3-31974515-2 4

Elbakidze, M., P. Angelstam, C. Sandström, and R. Axelsson. 2010. Multi-stakeholder collaboration in Russian and Swedish Model Forest initiatives: adaptive governance towards sustainable forest management? Ecology and Society 15(2):14.

Fomenko, N. M. 2017. Enterprise integration in the network electronic market: Choice of the Internetproject implementation directions. In: Managing Service, Education and Knowledge Management in the Knowledge Economic Era (pp. 37-40). CRC Press.

Gerasimov, Yu., and T. Karjalainen. 2006. Development of wood procurement in Northwest Russia: round wood balance and unreported flows. Eurpean Journal of Forestest Resources 125: 189-199.

Ioffe, G., and T. Nefedova. 2004) Marginal farmland in European Russia. Eurasian Geography xx

Knize, A., and B. Romanyuk. 2006. Two opinions of Russia's forest and forestry. Moscow: WWF Russian Programme Office

Kovalev, S. A. 1974. Regional Peculiarities in the Dynamics of Rural Settlement in the USSR (195970). Soviet Geography 15(1):1-12.

Kropinova, E. 2012. Agro- and Rural Tourism in the Baltic Sea region. A Growing Sector. Rural Development and Land Use. Ecosystem, Health and Sustainable Agriculture 3:130-140.

Leonard, C. S. 2010. Agrarian Reform in Russia: the road from serfdom. Cambridge University Press.

Naumov, V., P. Angelstam, and M. Elbakidze. 2016. Barriers and bridges for intensified wood production in Russia: Insights from the environmental history of a regional logging frontier. Forest Policy and Economics 66:1-10. 
Nefedova, T. 2011. Russian rural Nechernozemye: Collapse or new ways of development? Geography, Environment, Sustainability 4(4):10-23.

Palang, H., A., Printsmann, E. K. Gyuro, M., Urbanc, E., Skowronek, and W. Woloszyn. 2006. The forgotten rural landscapes of Central and Eastern Europe. Landscape Ecology 21(3):347-357.

Pallot, J. 1999. Land reform in Russia, 1906-1917: peasant responses to Stolypin's project of rural transformation. Clarendon press.

Roll, G.,T., Maximova, and E. Eero Mikenberg. 2001. The external relations of the Pskov region of the Russian Federation. Schleswig-Holsteinisches Institut für Friedenswissenschaften an der ChristianAlbrechts-Universität zu Kiel (SCHIFF). SCHIFF-texte Nr. 63:3-45.

Romanyuk B., A. Knize, S. Shinkevich, G. Zakharov, and A. Kudryashova. 2005. Thinning schedules for intensive forest management, Saint Petersburg Forest Research Institute.

Romanyuk B.D, Zagidullina AT, Knize AA (2001) Planning forestry on a nature conservation basic WWF, Pskov model forest. (in Russian)

Romanyuk, B., A. Zagidullina, A. Knize, and E. Mosyagina, 2006, Nature conservation basics for forestry planning for the North- Westernregion of Russia. Sustainable forestry, № 2,3 (in Russian)

Saraykin, V., R. Yanbykh, and V. Uzun. 2017. Assessing the potential for Russian grain exports: a special focus on the prospective cultivation of abandoned land. In The Eurasian Wheat Belt and Food Security (pp. 155-175). Springer, Cham.

Savignac, D. (editor and translator). 2016. The Pskov 3rd Chronicle., 2nd edition. Crofton, UK. (https://sites.google.com/site/pskovrelease3/)

Сушков, С. Ф., and Брулева, М. В. 2006. Аграрное развитие Санкт-Петербургской губернии в Хix веке. Известия Российского государственного педагогического университета им. А.И. Герцена, 6 (16).

Tomson, P., R. G. H. Bunce, and K. Sepp. 2015. The role of slash and burn cultivation in the formation of southern Estonian landscapes and implications for nature conservation. Landscape and Urban Planning 137:54-63.

Warner, E. A. 2000. Russian peasant beliefs and practices concerning death and the supernatural collected in Novosokol'niki Region, Pskov Province, Russia, 1995. Part II: Death in natural circumstances. Folklore 111(2): 255-281.

Yablochkina, E.M., B.D. Romanyuk, and E.A. Chernenkova. 2007. The WWF project "Pskov Model Forest". Moscow and Strugy-Krasnye: WWF Russia.

Zubarevitch, N.V. 2017. Rural development in Russia: social and gender issues. International Agricultural Journal 2: 12-14. 


\section{Poland and Belarus: Narew catchment, Bialowieza forest}

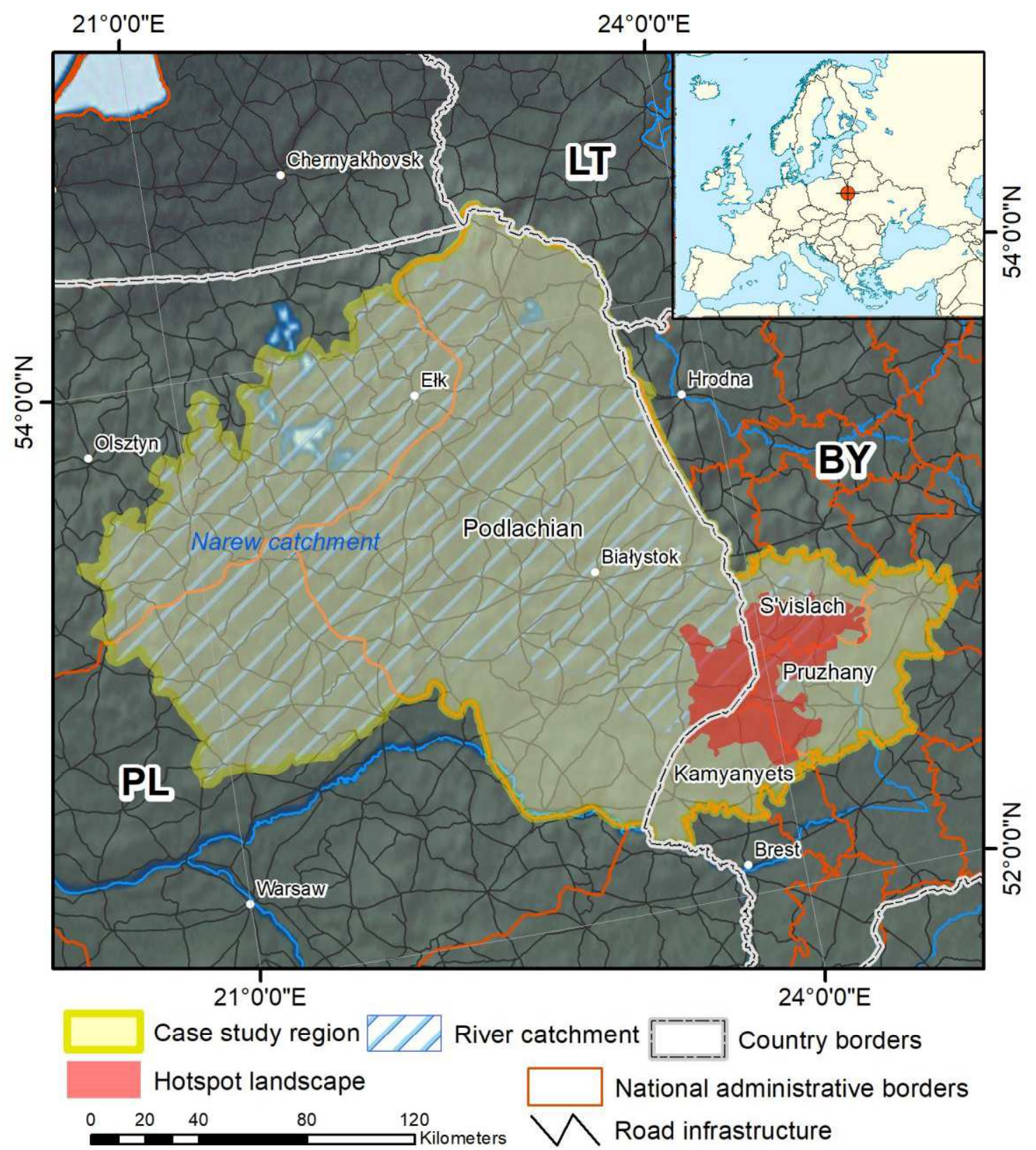

Summary of case study region and hotspot landscape

Podlaskie (Podlachia) is a province in NE Poland bordering Lithuania and Belarus. This is a low-lying partly forested area mostly within the Narew river catchment, with a varied relief and postglacial lakes, marshland, and peat bogs. Podlaskie is one of the least economically developed of all Polish provinces, and thus maintains a wealth of species of Polish and EU conservation concern (Edman et al. 2011).

For centuries Białowieża Forest Massif (BFM) has been a borderland between states (e.g., between the Polish Kingdom and Lithuanian Duchy, and now between Poland and Belarus), religions and beliefs (Christian vs. pagan; catholic vs. orthodox) and cultures (West (Masovian) vs. East (Dregovichi); Roman vs. Byzantine). This has shaped the landscape as a diverse social-ecological system. The 
Białowieża Forest massif covers $1,500 \mathrm{~km}^{2}$ within the limits of Hajnówka County in Poland with 43,700 inhabitants, and Kamenetskij and Svislotskij districts in Belarus with 39,000 and 9,500, respectively. The BFM has been inhabited since at least 6,000 years BP (Latałowa et al. 2016). Until the beginning of the 20th century use of natural resources was limited in time and space, with the prevailing function as a Polish royal/Russian imperial hunting ground during the $15^{\text {th }}$ to 19 th centuries (Samojlik et al. 2013). The beginning of the 20th century brought logging and tree planting on clearfelled sites, as well as establishment of one of the first protected areas in Poland in 1921. In the 1940s the BFM became divided between Poland (PL) and Belarus (BY). Nature conservation, eventually combined with hunting ground of the Soviet political elite (nomenklatura), was a priority in the BY part of the BFM, which in 1991 became a Belarusian national park. Parts of the BFM have been used for wood production, gradually replaced by nature conservation and tourism, which accelerated at the beginning of $1990 \mathrm{~s}$. Currently, $>35 \%$ of the Polish part of the BFM is protected as a national park and nature reserves. The entire BFM area is designated by international nature conservation approaches, including Natura 2000 in the Polish part (since 2004), UNESCO Biosphere Reserve (since 2005 in Poland), Biosphere zapovednik (since 1993 in Belarus), and transboundary UNESCO World Heritage site (since 2014) (Jaroszewicz et al. 2019). The BFM is subject to intensive debates about what the most effective means of conservation are (Blicharska et al. 2020).

\section{Traditional fora}

The patterns of social interactions were different in time and space, depending on the nationality, social status and cultural/religious practices. Until the 18th century BFM was closed for expansion of settlements by a chain of guarding villages at the edge of the forest, which were inhabited by royal guards, riflemen and beaters (Samojlik et al. 2013). For them very important fora were their administrative centres and churches (Catholic, Orthodox, Uniate). For peasants living in the communities outside the BFM, and inside since the $18^{\text {th }}$ century, traditional village councils, the churches and inns were the key traditional meeting points. In the villages many social interactions in the closest neighbourhood took place at the traditionally placed benches in front of the houses along the village street, where people met to exchange information and ideas (Moroz-Keczyńska 2003). There was also a very numerous Jewish community in the $18^{\text {th }}$ to $20^{\text {th }}$ centuries, which due to different culture, religion and occupation lived in partial isolation. They used their own fora such as kahals and synagogues. Additionally, there was a society of nobilities, which met with the farmers in the churches, but had their own fora through events in their mansions, which excluded peasants and Jews. The $20^{\text {th }}$ century brought many changes in this social "landscape". During World War I many prisoners of war were used to log the forest (Hedemann 1939). Some of them stayed in the region after the war, and together with seasonal forest workers created new class of forest and industry workers for which, aside of the churches, the main fora were trade unions and quite strong communistic party movement. After World War II the situation changed abruptly, separating the Belarusian and Polish parts of the BFM. In Belarus, due to collectivisation all, traditional fora officially were disbanded and replaced by communistic networking. In Poland collectivisation did not take place, but a big part of the pre-war society disappeared (the whole Jewish community, nobilities and majority of industrial workers). In recent decades the Polish part of the BFM rural areas are becoming depopulated due to migration of youngsters to the cities or abroad (Brol 2015). A large share of the villagers are elderly retired farmers still cultivating traditional ways of information exchange using traditional fora, which causes limited social interactions with the outer world.

\section{New fora}

Today, in the Belarussian part of BFM the central role of social interaction is played by the national park, which is the main employer in the region (over 1000 employees). In the Polish part of BFM local 
municipalities are recently caught in the middle of the conflict between the wood production and conservation sectors. The former is promoted by the very strong National Forest Holding (NFH) and traditional rural community members, while the latter reflects non-timber forest use, mainly ecotourism, which is promoted by part of the younger generation, a considerable number of migrants from other parts of Poland, and the scientific community. This conflict has created a very strong polarization in the local Polish society and the struggle is still not solved (Niedziałkowski et al. 2019). Paradoxically introduction of different nature conservation approaches (Natura 2000, Biosphere Reserve, World Heritage) has not solved but exacerbated the conflicts, because these approaches were contested by local foresters (NFH), a very influential group of members of the local communities (Niedziałkowski 2016). Due to this strong polarization, deep distrust among the key stakeholders (local municipalities, NFH, NGOs, scientific community) and lack of neutral trustable negotiators, the attempts to resolve the competing interests have not been successful. In Belarus the situation is simpler, because the goals of development are clear owing to the national park with a spatial zoning approach encompassing the entire Belarusian part of the BFM.

\section{Virtual fora}

During the last two decades many new grass-roots NGOs have developed, which are using both traditional and virtual fora for their activities. Virtual means, based on the internet are used for debates over threats to and opportunities for local development, to arrange social events and meetings, and in Poland to organize protests against plans to continue wood extraction vs. expansion of nature conservation. The conflict about the Polish part of the BFM has been transplanted from the real to virtual fora, and has become even more intensive than it used to be.

\section{Summary related to social capital framework}

The current high rate of emigration from most local rural communities in the BFM is of serious concern. Additionally, the disadvantageous demographic structure of these communities with a high proportion of elderly people causes difficulties in maintaining and reviving social capital forms. In general, the local economy is weak (Wesołowski et al. 2018). However, the Białowieża municipality in Poland hosting the Białowieża National Park administration and a wealth of facilities for tourists, with its positive demography and the most developed economy in the region, provides good evidence that nature-based tourism can support revitalisation of some communities (Wesołowski et al. 2018). This case study demonstrates multiple difficulties in securing bonding, bridging and linking social capitals. This is caused by conflicts over the management of forest resources and natural values, lack of a vision for future development and of political will to find a compromise (Blicharska et al. 2020). Thus, supporting and maintaining social capital remains an urgent issue.

\section{Literature cited}

Blicharska, M., P. Angelstam, J.B. Jacobsen, L. Giessen, J. Hilszczanski, E. Hermanowicz, J. Holeksa, B. Jaroszewicz, A. Konczal, A. Konieczny, G. Mikusinski, Z. Mirek, B. Muys, F. Mohren, K. Niedzialkowski, T. Samojlik, M. Sotirov, K. Sterenczak, J. Szwagrzyk, G.M. Winder, Z. Witkowski, R. Zaplata, and G. Winkel. 2020. Contested evidence and the multifaceted nature of biodiversity conservation and sustainable land use - the emblematic case of Białowieża Forest. Biological Conservation, in revision

Brol, W. 2015. Prognoza ludności GUS 2014-2050 - Mapy. https://wbdata.pl/prognozy-ludnosci-gus2014-2050-mapy/ (accessed 2019-10-04).

Edman, T., P. Angelstam, G. Mikusinski, J.-M., Roberge, and A. Sikora 2011. Spatial planning for biodiversity conservation: Assessment of forest landscapes' conservation value using umbrella species requirements in Poland. Landscape and Urban Planning 102: 16-23. 
Hedemann, O. 1939. L'histoire de la Foret de Białowieża (Jusqu'a 1798); Instytut Badawczy Lasów Państwowych: Warsaw, Poland,; Rozprawy i Sprawozdania Seria A, Nr 1.

Jaroszewicz, B., O. Cholewińska, J.M. Gutowski, M. Zimny, T. Samojlik, and M. Latałowa. 2019. Białowieża Forest - A Relic of the High Naturalness of European Forests. Forests 10: 849.

Latałowa, M., M. Zimny, A. Pędziszewska, and M. Kupryjanowicz. 2016. Postglacjalna historia PuszczyBiałowieskiej—roślinność, klimat i działalność człowieka. [Postglacial history of the Białowieża Forest - vegetation, climate and human activity]. Parki Narodowe i Rezerwaty Przyrody 35: 3-49.

Moroz-Keczyńska, E. 2003. Z kuferka babuni - czyli tajemnice odkrywane na strychu: Dlaczego na wsiach przed domami stawiano ławeczki, czyli o tym, że grunt to mieć sąsiada, a najlepiej jeszcze dobrze poinformowanego. Puszczyk 5: 9-10.

Niedziałkowski K. 2016. Why do foresters oppose the enlargement of the Białowieża National Park? The motivation of the State Forests Holding employees as perceived by social actors engaged in the conflict over the Białowieża Forest. Forest Research Papers / Leśne prace badawcze 77(4):358-370

Niedziałkowski K., B. Jaroszewicz, R. Kowalczyk, D.P.J. Kuijper, G. Mikusiński, N. Selva, W. Walankiewicz, and T. Wesołowski. 2019. Effective mitigation of conservation conflicts and participatory governance: reflections on Kuboń et al. Conservation Biology 33:962-965.

Samojlik, T., I.D. Rotherham, and B. Jędrzejewska. 2013. The cultural landscape of royal hunting gardens from the fifteenth to the eighteenth century in Białowieza Primeval Forest. In: Cultural Severance and the Environment. I.D. Rotherham (Ed.), Springer: Dordrecht, The Netherlands, pp. 191-204.

Wesołowski, T., J.M. Gutowski, B. Jaroszewicz, R. Kowalczyk, K. Niedziałkowski, J. Rok, and J.M. Wójcik. 2018. Park Narodowy Puszczy Białowieskiej-Ochrona Przyrody i Rozwój Lokalnych Społeczności. [The National Park of the Białowieża Forest-Nature Conservation and Development of Local Communities]. pp. 1-28. Available online: www.forestbiology.org (accessed 2019-10-04). 


\section{Lithuania: Dzūkija region, Dzūkija National Park}

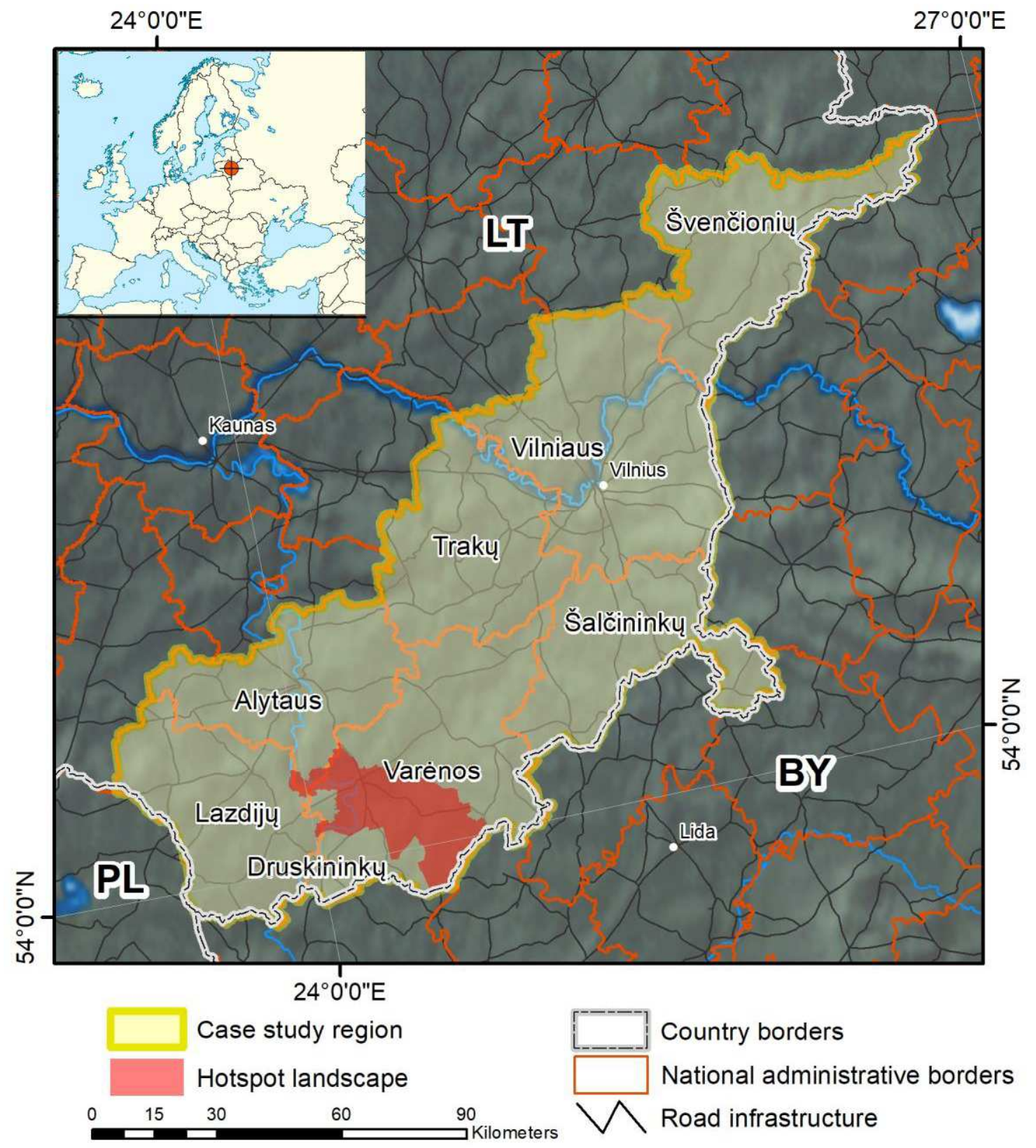

Summary of case study region and hotspot landscape

Dzūkija is an informal cultural region Lithuania defined by traditional forest-dependent lifestyles of rural farmers with local dialects (Ragauskaite and Daugirdas 2010). It is located in southeast Lithuania near the Nemunas River and along the Belarusian border, with Alytus County at its centre. It represents the temperate and hemi-boreal forest ecoregions. Large parts of southern Dzukija have light sandy soils, which are unsuited for agriculture. Therefore, it is dominated by Scots pine (Pinus sylvestris) forests, which form one of the largest contiguous forest tracts in Lithuania. Lithuania is losing population at increasing rates since the early 1990s, and is now among the fastest shrinking countries in the world (Ubarevičiene et al. 2016). Southern Dzūkija is also the most sparsely populated region in 
Lithuania, and with human population density declining 2-3\% per year (Ubarevičienė et al. 2016, Ubarevičiene and Van Ham 2017). Dzukija's ancient culture is tied to traditional arts and crafts that can still be found today. Due to lower agricultural harvests on infertile soils, the region was poorer than the rest of Lithuania.

Dzūkija National Park (DNP) is a good example of the Dzūkija region, and has a forest cover of $85 \%$. The State Forest Enterprise owns about 50 percent of DNP's forests, and the rest is owned by private companies or individuals. The number of non-industrial private forest owners is currently unknown. For the majority of the population wood and non-wood forest products have always been the main source of income. For example, farmers collected edible mushrooms and berries; mushroom gathering remains an important component of the local economy. The DNP contains the villages Zervynos and Musteika with homesteads and buildings officially declared as cultural heritage (e.g., Povilaitienè and Mačiukėnaite 2014). There are archaeological records from the Stone and Iron Ages.

\section{Traditional fora}

Previously life and culture were built on traditional agriculture and forestry, with local markets, traditional village councils, libraries and the church being key meeting points for both social and business purposes. Formation of Soviet collective agricultural farm villages started in 1948

(Balbieriene and Marcinkevičius 2017). Through their subsequent abandonment by the younger generations since the 1990's, many villages are facing issues with populations that are ageing and in decline. Nevertheless, many of Dzukija's villages still remain as the key meeting points. However, the current engagement of traditional fora is not as active as in the past, but older residents still indulge in the past traditions linked to traditional fora.

\section{New fora}

The DNP was established in 1991 and is the largest protected area in Lithuania $\left(585 \mathrm{~km}^{2}\right)$. DNP is designated as Natura 2000 area under the EU bird and habitat directives and offers facilities for tourists (Kriaučiūnas et al. 2010). The main body for land governance and planning is the DNP, which employees 35 administration staff. As Lithuanian protected areas are complex and do not align with the IUCN categories of protected areas (Lazdinis 2011), forest management activities are undertaken in the DNP, but are not part of the DNP portfolio. Forestry is carried out by both the State's Forestry Department and private land holders. DNP forests are divided into four functional groups: i) reserves $(18 \%)$, ii) forest for protection of ecosystems $(11 \%)$ and recreational forests $(1 \%)$, iii) protective forests (35\%), and iv) commercial forests (34\%) (State Forest Service 2017). The aim is of the DNP is to protect the landscape, the old villages, historical and cultural monuments, and forests of south-eastern Lithuania. Within the DNP there are three conservation reservations, and 28 reserves including eight landscape reserves, 16 nature reserves, and four cultural reserves. DNP contains 12 historical, 25 archaeological, 10 architectural and 35 art monuments. The Čepkeliai raised bog adjoining the DNP has limited anthropogenic impact butis used for cutting of grass and collection of cranberries by licenced locals. It was established during Soviet time as a wilderness area in 1961 and the Čepkeliai Strict Nature Reserve (zapovednik) was established in 1975 and was nominated as Ramsar wetland area together with connecting Kotra Landscape Reserve in Belarus in 1993. The establishment of the DNP was expected to attract tourists, generate economic activity so that local people could continue to live from traditional means and their traditions would be protected by balancing social and economic aspects. People have lived in harmony with nature in Dzukija for centuries and this is the main value of DNP. However, the quest for a balance between nature conservation and economic use of the forests is a continuous unresolved process in the DNP. A summer home-owner from a rural village has highlighted problems where the traditional fora meet with the new and virtual fora by stating "In 
Margionys (a small remote village based on forest traditions) we are part of the local village association. The primary means of communication is done by putting up announcements on the local events board in the village. However, only approximately $50 \%$ house owners live in the village." Thus, small villages still face challenges to survive (Pawlewicz et al. 2019). On a positive note: business opportunities have arisen with the establishment of two cafes that act meeting places within the local villages. But the success of these new businesses will be largely reliant on the demand of tourist because local people generally do not have the means to utilize these facilities or services.

\section{Virtual fora}

There appears to be a three-way divide between (1) the younger and older generations, (2) level of financial security, and (3) business and non-business orientated groups that influence the effectiveness of the virtual fora. The uptake of virtual fora is mostly by the younger generation or tech savvy people with business orientation or financial security. However, the older folk still use the markets, church and traditional forms for communication. This is highlighted by within the Dzukija Region with tourism operators and caterers using electronic media and web-based applications to attract tourists. Visitor interpretation centres (e.g., National park offices) established in Merkys (head office) and Marcinkonis (former head office) are three examples.

\section{Summary related to social capital framework}

The DNP area is facing increased pressure from rural abandonment and thus a loss of traditional practices and traditional cultural landscapes. Ubarevičienè et al. (2016) emphasized the need for spatial planning to cope with rural decline. During the late 1990s a rural community movement emerged in post-socialist Lithuania (e.g., Juskas et al. 2005). This is an approach that aims to strengthen all forms of social capital. The establishment of collaborative learning using a landscape approach in DNP could provide necessary insights about ongoing processes in the territory (e.g. Angelstam et al., 2019). This could lead to potential increases in the capacity of stakeholders working in the DNP area to address emerging social-ecological problems.

\section{Literature cited}

Angelstam, P., M. Manton, M. Elbakidze, F. Sijtsma, M. C. Adamescu, N. Avni, .. . and T. Yamelynets. 2019. LTSER platforms as a place-based transdisciplinary research infrastructure: learning landscape approach through evaluation. Landscape Ecology 34(7):1461-1484.

Balbierienè, V.K., and D. Marcinkevičius. 2017. Tendencies of Transformations in Rural Landscape of the Former Collective Farm Villages of Lithuania. Journal of Sustainable Architecture and Civil Engineering 19(2):13-28.

Juska, A., A. Poviliunas, and R. Pozzuto. 2005. Rural grass-roots organizing in Eastern Europe: the experience from Lithuania. Community Development Journal 41(2): 174-188.

Kriaučiūnas, E., A. Alksnyte, and D. Burneika. 2010. Turizmo paslaugų išvystymo ypatumai Aukštaitijos, Dzūkijos ir Žemaitijos nacionaliniuose parkuose. Annales Geographicae 43(1-2): 6475.

Lazdinis, M. 2011. Implementation of international requirement for protected areas in Lithuanian forestry. In: Legal aspects of European Forest Sustainable Development. Proceedings of the $13^{\text {th }}$ International Symposium. Kaunas, Lithuania. IUFRO.

Pawlewicz, K., A. Senetra, M. Gwiaździńska-Goraj, and D. Krupickait.è 2019. Differences in the Environmental, Social and Economic Development of Polish-Lithuanian Trans-Border Regions. Social indicators research on line. https://doi.org/10.1007/s11205-019-02179-9

Povilaitienè, I., and J. Mačiukènaite 2014. Identity features of spatial structure in small cities, towns and villages in Dzūkija. Journal of Sustainable Architecture and Civil Engineering 7(2): 43-53. 
Ragauskaite, A., and V. Daugirdas 2010. Dzukijos kulturinis regionas. Annales Geographicae 43-44: 16-28.

State Forest Service 2017. Lithuanian statistical yearbook of forestry 2017. Valstybinè miškų tarnyba, Kaunas.

Ubarevičienè, R., and M. Van Ham. 2017. Population decline in Lithuania: who lives in declining regions and who leaves? Regional Studies, Regional Science 4(1):57-79.

Ubarevičienè, R., M. Van Ham, and D. Burneik.a 2016. Shrinking regions in a shrinking country: The geography of population decline in Lithuania 2001-2011. Urban Studies Research, Article ID 5395379, 18 pp. 


\section{Sweden N: Jokkmokk municipality, Änok/Kvikkjokk}

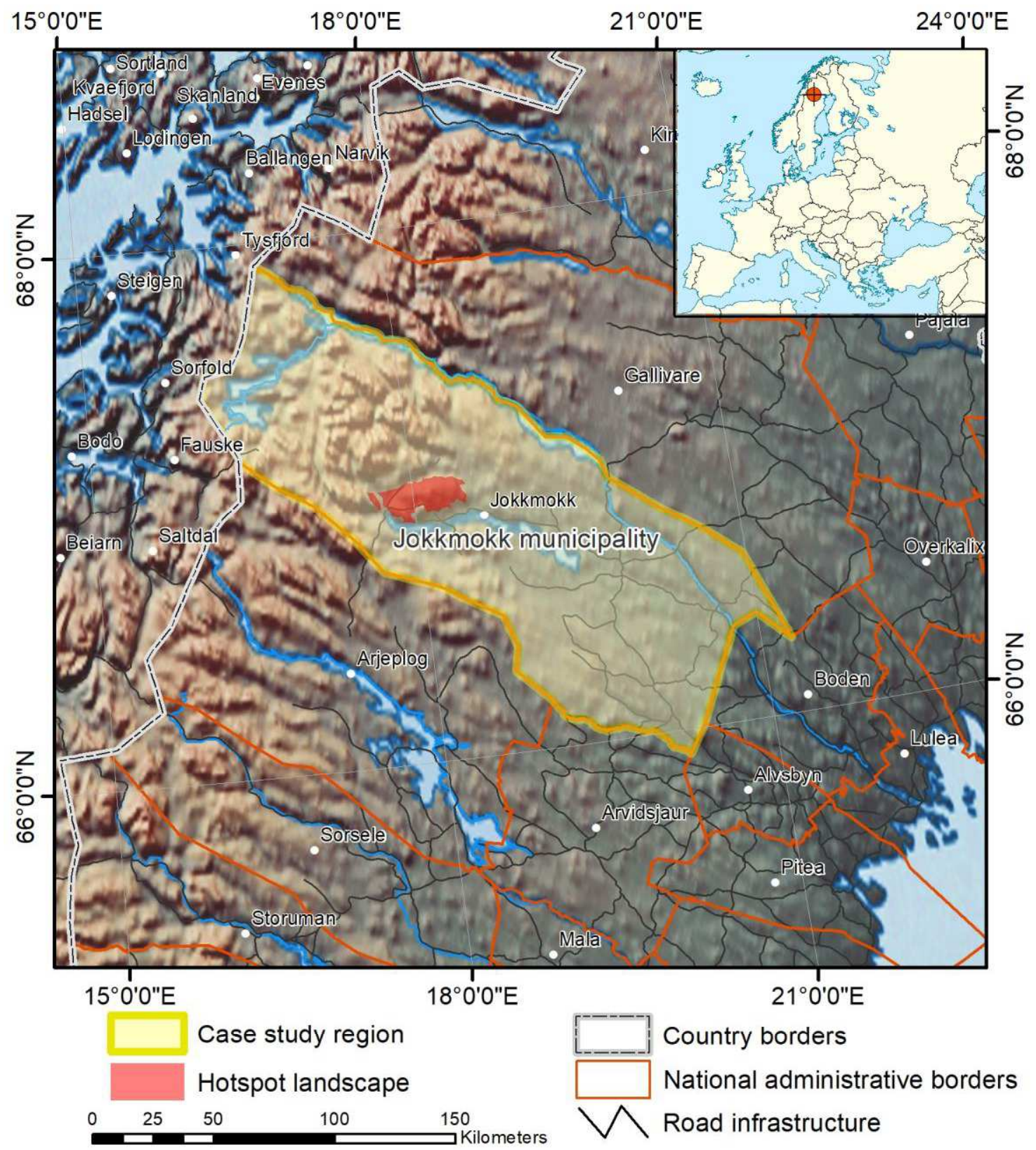

\section{Summary of case study region and hotspot landscape}

Jokkmokk municipality covers $>19,000 \mathrm{~km}^{2}$, is located at the Arctic Circle, and extends from high mountains and the EU's last large intact forest landscapes in the west, to managed lowland boreal forests in the east (Jonsson et al. 2019). As part of Sápmi, the land of the Sami people across four nations for thousands of years, Jokkmokk is a traditional meeting place for Sami trade, gatherings and festivals. The historic Jokkmokk winter market is a prime example with the 415 th consecutive event to be held in 2020. Jokkmokk is also a meeting place between its five Sami villages and the Swedish territorial expansion. Jokkmokk is divided between the east with settlements founded for farming and forestry, and the sparsely populated west. The population in Jokkmokk increased from 2700 residents 
in 1890 (of which 2140 Sami) to over 11,000 in 1960, but declined to just below 5,000 in 2019. This coincided with the dramatic decline in jobs provided by forestry and hydropower development. After a century of dependence these natural resources there is now a process seeking alternative mechanisms for economic development (Carson et al. 2016). Tourism linked to Sami heritage is limited by cultural norms and legal obstacles (Müller and Huuva 2009). Nevertheless, the Jokkmokk forest commons focuses on wood production, and there is resistance towards natural conservation investments. Hosting a third of EU's last intact forest landscapes provides opportunity for development of value chains supporting rural development (Jonsson et al. 2019).

During 1661-1702, silver was mined near Kvikkjokk village in the west, and a smelter was built. Apart from soldiers and Sami people only government officials and a priest lived there. By 1796 only two Swedish homesteads had been established in Kvikkjokk. The famous naturalist Carl von Linné studied the flora and praised the landscape. This heritage contributed to arousing the Swedish tourist association's interest in placing a mountain station there, and so did the belief that nearby Sulitelma was Sweden's highest mountain. The earliest history of tourism can be traced back to 1887 when the first marked hiking trails were established with Kvikkjokk as starting point. The mountain station in Kvikkjokk was built in 1928, and still offers services to hikers. The two large national parks Padjelanta and Sarek border the area. Due to a long-term conflict about the Änok area - a strip of privately-owned forest land located between the Kvikkjokk-Kabla $\left(492 \mathrm{~km}^{2}\right)$ and Pärlälven $\left(1157 \mathrm{~km}^{2}\right)$ nature reserves the Kvikkjokk area has become an iconic illustration the competition between establishing sustained yield forestry in high conservation value forest areas vs. conservation of values linked to one of the EU's last intact forest landscapes. This case illustrates the complexity of different stakeholders' views and narratives, political directions and judicial decisions (Jonsson et al. 2019).

\section{Traditional fora}

The Kvikkjokk area has a long history of integrated co-existence between Sami people and Swedish homesteaders. The latter arrived in the late $17^{\text {th }}$ century, and the main resources for self-subsistence were animal husbandry and hay-making on seasonally flooded natural meadows on both privately and commonly owned land, limited agriculture, hunting and fishing as well as use of other non-wood forest products including pearl mussel fishing. This frontier period lasted until the 1940s. Over this period the village was also a forum for local conflict resolution and decision-making. Road access was established in 1957, prior to that tourists arrived by boat. Today, moose hunting groups are a strong informal type of forum and reflect conventional material natural resource use views.

\section{New fora}

The legacies of Sami culture and being a frontier of natural resource exploitation has led to a range of new fora. Ájtte is since 1989 the principal Swedish museum of Sami culture, a special museum for the mountain region, and an information centre for mountain tourism. The large national parks in Jokkmokk areas form Laponia - a world heritage site founded in 1996 by UNESCO. Green (2009) showed "how the involvement of international agencies and global protection aspirations, such as the World Heritage Convention, might establish a link between the local and international levels that to a certain extent bypasses the national level and empowers indigenous/local peoples and their ethnopolitical objectives." The Taiga Rescue Network (1992-2010) was formed in Jokkmokk to exchange knowledge about boreal forests globally. The Sami Folk High School arranges adult education aimed at revival of Sami heritage. Jokkmokk municipality officials are actively engaged in pursuing transnational projects with an arctic periphery profile (e.g., http://w-power.interreg-npa.eu/). Finally, in summer 2019 Jokkmokk hosted a Rainbow Gathering, which is a loosely knit community of people, who congregate annually in remote forests around the world with the stated intention of living a shared 
ideology of peace, harmony, freedom, and respect. To express solidarity with Sami-Sweden conflict on customary hunting more than 1000 persons gathered at the holy Átjek Sami hill and the iron mine prospecting at Gallak/Kallak by the international company Beowulf Mining.

\section{Virtual fora}

The internet is used in a confrontative rather than a collaborative manner. This applies to environmental NGOs (ENGOs), forest owner associations and Jokkmokk municipality. The highest concentration of large intact forests in Sweden is found in Jokkmokk, and the frontier of wood mining and hydropower development, did put these topics on the international scene already in the 1990s. The anti-mining campaign in Kallak illustrates how social media use can extend a place-specific protest by linking it to a global issue such the mining boom and subsequent consequences for indigenous people (DahlbergGrundberg et al. 2017). Social media also enabled the realisation of a Rainbow Gathering on the same theme.

\section{Summary related to social capital framework}

Currently there is a gap in communication and value systems between tourists, increasingly of foreign origin, and advocates of value chains built on immaterial landscape values on the one hand, and summer cottage holders and local residents with "boreal masculine motorized" ideals on the other. The municipality's attitude reflects a conventional north Swedish material focus on logging/industrial forestry, hydropower and mining. Bottom-up governance initiatives are limited. Instead the vertical dimension of social capital is top-down and run by forest owner associations as a means of advocating the protection of land ownership rights. There is no local arena for dialogue and knowledge exchange. The world heritage site Laponia offers a potential model for landscape approach with Sami influence (Green 2009, Reimerson 2016). However, according to Nilsson Dahlström (2009) Sami indigenous knowledge is being integrated with Swedish environmental management policies, and will have to be made to "fit in" in order to become legitimate knowledge. Nevertheless, the necessary spatial land use planning to accommodate multiple ecosystem services by land sparing is not feasible in today's political situation where the belief in traditional natural resources remain.

\section{Literature cited}

Abram, S. 2016. Jokkmokk: Rapacity and resistance in Sápmi. In: Postcolonial Perspectives on the European High North (pp. 67-92). Palgrave Macmillan, London.

Carson, D.B., D.A. Carson, G. Nordin, and P. Sköld. 2016. Lessons from the Arctic past: The resource cycle, hydro energy development, and the human geography of Jokkmokk, Sweden. Energy Research \& Social Science 16:13-24.

Dahlberg-Grundberg, M., and J. Örestig. 2017. Extending the local: activist types and forms of social media use in the case of an anti-mining struggle. Social Movement Studies 16(3):309-322.

Dahlström Nilsson, Å. 2003. Negotiating wilderness in a cultural landscape: predators and Saami reindeer herding in the Laponian World Heritage Area (Doctoral dissertation, Acta universitatis upsaliensis).

Müller, D.K., and S.K. Huuva. 2009. Limits to Sami tourism development: The case of Jokkmokk, Sweden. Journal of Ecotourism 8(2):115-127.

Müller, D.K., and R. Pettersson. 2006. Sámi heritage at the winter festival in Jokkmokk, Sweden. Scandinavian Journal of Hospitality and Tourism 6(01):54-69.

Müller, D.K., and P. Brouder. 2014. Dynamic development or destined to decline? The case of Arctic tourism businesses and local labour markets in Jokkmokk, Sweden. Tourism destination development: Turns and tactics, pp.227-244. 
Green, C. 2009. Managing Laponia. A World Heritage Site as Arena for Sami Ethno-Politics in Sweden. Acta Universitatis Upsaliensis. Uppsala Studies in Cultural Anthropology 47. $221 \mathrm{pp}$. Uppsala. ISBN 978-91-554-7656-4.

Jonsson, B.G., J. Svensson, G. Mikusiński, M. Manton, and P. Angelstam. 2019. European Union's last intact forest landscape is at a value chain crossroad between multiple use and intensified wood production. Forests 10(7): 564.

Lloyd, S. 2001. The Emerging Forest Landscape of Sweden. A Case Study of Relationships between Socioeconomic and Ecological Space in Jokkmokk, A Master's thesis, Department of Rural Development Studies, Swedish University of Agricultural Sciences. Mimeo.

Lloyd, S., 2001. Change in rural forest communities: The case of Jokkmokk, Sweden. Forests, Trees and People Newsletter (FAO/Sweden).

Lindahl, K. 1998. Forests and Forestry in Jokkmokk Municipality. In European Regional Meeting on the Underlying Causes of Deforestation and Forest Degradation in Europe, Bonn (pp. 28-29).

Nilsson Dahlström, A. 2009. The two-way appropriation of indigenous knowledge: environmental management policies and the Laponia process. Journal of Northern Studies, (2), pp.39-57.

Horstkotte, T., C. Sandström, and J. Moen. 2014. Exploring the multiple use of boreal landscapes in northern Sweden: The importance of social-ecological diversity for mobility and flexibility. Human Ecology 42(5):671-682.

Norstedt, G. 2014. It is the Sámi Who Own This Land: Sacred Landscapes and Oral Histories of the Jokkmokk Sámi, edited by Tero Mustonen and Eija Syrjämäki. Arctic 67(2):263-264.

Reimerson, E. 2016. Sami space for agency in the management of the Laponia World Heritage site. Local Environmen, 21(7):808-826.

Viken, A., and B. Granås. 2016. Dynamic Development or Destined to Decline? The Case of Arctic Tourism Businesses and Local Labour Markets in Jokkmokk, Sweden. In Tourism Destination Development (pp. 241-258). Routledge.

Zachrisson, A., and K.B. Lindahl. 2013. Conflict resolution through collaboration: Preconditions and limitations in forest and nature conservation controversies. Forest Policy and Economics 33:39-46. 


\section{Sweden S: Örebro County, Tiveden}

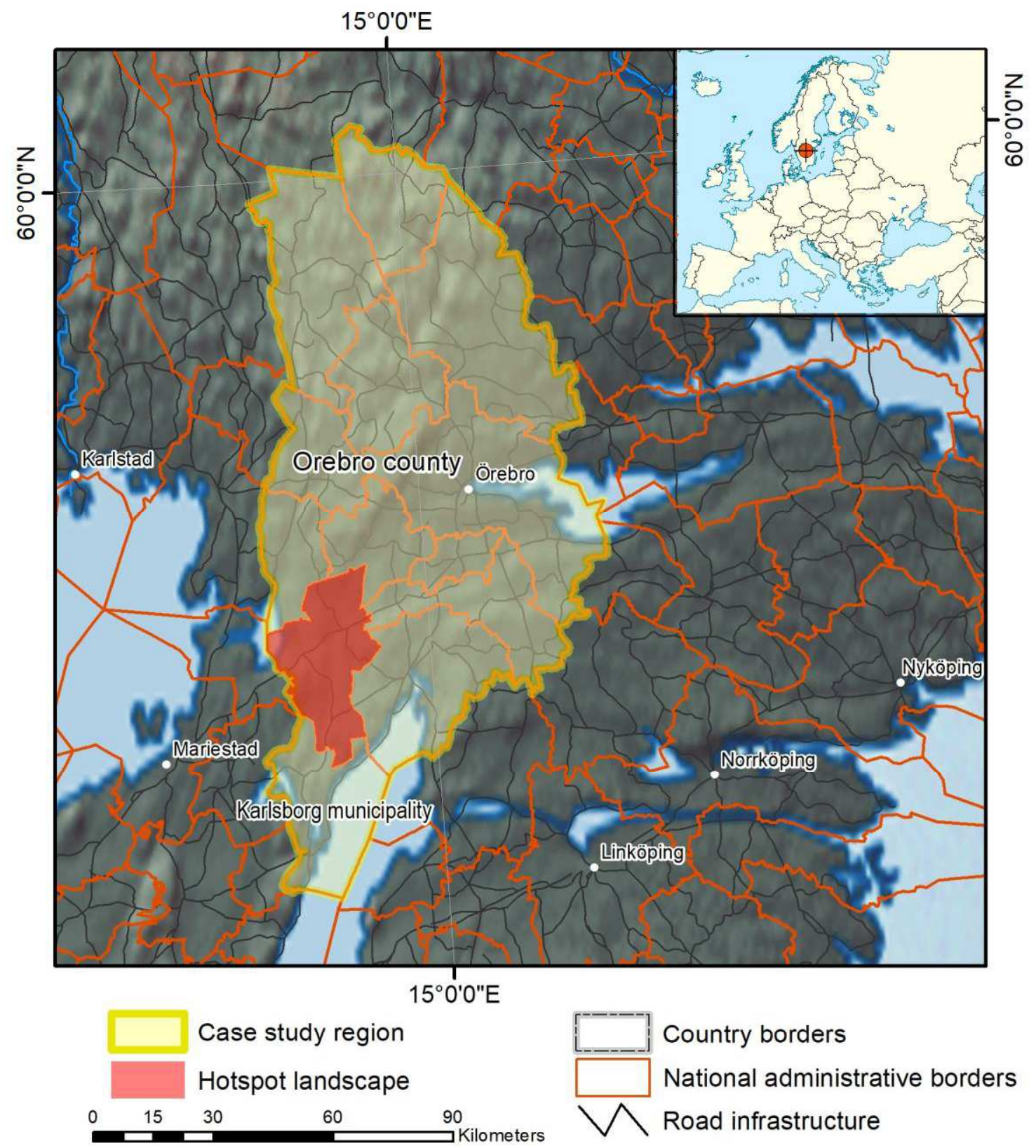

Summary of case study region and hotspot landscape

In Sweden frontiers of agricultural development and forest use have produced a gradient in forest cover from heavily cleared lowland areas now dominated by agriculture and urban areas in the south to upland areas with high forest cover in the north. This gradient is particularly steep in south-central Sweden's Örebro County (Elbakidze et al. 2017), which forms a borderland in terms of ecological, economic and socio-cultural landscape dimensions (Andersson et al. 2013). The region has a $>2000$ year long history of mining, use of forests for charcoal and later by forest industry, and from the Medieval period of energy from streams and rivers (Angelstam et al. 2015). After the economically successful mining and iron production era ended during the second half of the 20th century, Örebro 
County has developed a steep gradient between economically peripheral areas with population decline with a hinterland character and growing urban regional centres (Angelstam et al. 2013, Chiasson et al. 2019).

Tiveden is located in the southernmost part of Örebro County, and is a borderland for nature, culture and administrative divisions which is located between Sweden's two historic regions: Götaland in the south and Svealand in the north. "Ti" stands for the forest god and "ved" for inaccessible forest. Human use of Tiveden developed during the past 400 years from swidden/slash-and-burn agriculture and animal husbandry to charcoal production for the ironworks, and timber and pulpwood for the forest industry. This constituted the resource base of the rural population for a long time. Today, most of this local landscape is managed for intensive industrial wood production, and parts are protected as a Tiveden national park and some nature reserves. The Tiveden area is used as a means of branding Laxå municipality as a hotspot for ecotourism.

\section{Traditional fora}

Laxå municipality consists of four parishes, which were the past units for social interactions. For smallscale farming built on animal husbandry and crop production, the church and traditional village councils (byalag) were the key traditional meeting points in the past. Animal husbandry for milk production was a key component, and morning delivery to the milk truck was a meeting. Joint sport, fishing and hunting activities were other fora. During the second half of the 20th century the number of farmers as well as workers in forestry and industry fell sharply. For industry workers, trade unions and the socialdemocratic party later provided a forum. Today, new jobs and inhabitants in rural areas are based on outdoor recreation and nature-based tourism and commuting between rural housing and urban

jobs, both based on biodiversity and wilderness as key values. Having deteriorated drastically, new fora for maintaining and reviving social capital forms are increasingly needed.

\section{New fora}

Local NGOs and networks for rural development, cultural heritage, horse riding, sport and sport fishing are active. While hunting, especially for moose, engaged locals in the past, today hunters are increasingly of urban origin. To support the development and maintenance of sustainable landscapes, municipalities, nature-based tourism companies, forestry and civil society in Tiveden, local actors now collaboratively seek new ways for rural development (Angelstam 2019). In response to this trajectory, Laxå municipality has adopted a new strategy to diversify employment by strengthening the naturebased tourism-sector, effectively declaring itself as Sweden's first "ecotourism area". However, at the same time forestry intensification is encouraged to promote growth in bio-economy. Forests are thus becoming younger, and the divide in terms of near-natural forest structure and age distribution between protected areas and managed forests has become significant. To resolve the provision of competing ecosystem services the local network "Collaboration Tiveden" was established, using the principles of Model Forest based on partnerships towards sustainability as one type of landscape approach. Key stakeholders in this scheme include Laxå municipality, the State-owned Forest Company Sveaskog, and local nature-based tourism businesses. However, while integrated spatial planning at landscape scale is needed, different sectors lack appropriate tools for mapping their key assets and sustaining suitable management approaches.

\section{Virtual fora}

Virtual means for communication are commonly used (websites, facebook groups, blogs and e-mail lists) to gather people for events arranged to discuss threats to and opportunities for rural development, arrange social events and meetings of different local groups, as well as to protest again plans to introducing mining for battery metals and expansion of wind power. 


\section{Summary related to social capital framework}

This case study illustrates the crucial role of bonding social capital (among tourism entrepreneurs, neighbours in rural communities), bridging social capital (trusting relations between tourism entrepreneurs, the municipality and the state forest company), and linking social capital (persons with skills to connect local, national and international levels of governance). This has enabled the establishment of collaboration between tourism businesses, municipalities and the state forest company Sveaskog aimed and introducing alternatives to clear-felling forestry. Additionally, however, there is a need for spatial planning at the landscape level to accommodate intensive wood production, recreation forests and different forest habitat networks for conservation of species than cannot cope with intensive forest management.

\section{Literature cited}

Andersson, K., P. Angelstam, R. Axelsson, M. Elbakidze, and J. Törnblom. 2013. Connecting municipal and regional level planning: analysis and visualization of sustainability indicators in Bergslagen, Sweden. European Planning Studies 21(8): 1210-1234.

Angelstam, P. 2019. Samverkan Tiveden. Dokumentation av en dialogprocess om skogslandskap som grön infrastruktur för landskapsutveckling. Skogsstyrelsen, Rapport 8. http://skogsstyrelsen.se/globalassets/om-oss/publikationer/2019/rapport-2019-8-samverkantiveden.pdf

Angelstam, P., K. Andersson, M. Isacson, D.V. Gavrilov, R. Axelsson, M. Bäckström, E. Degerman, M. Elbakidze, E. Yu. Kazakova-Apkarimova, L. Sartz, S. Sädbom, and J. Törnblom. 2013. Learning about the history of landscape use for the future: consequences for ecological and social systems in Swedish Bergslagen. Ambio 42(2): 150-163.

Angelstam, P., K. Andersson†, R. Axelsson, E. Degerman, M. Elbakidze, P. Sjölander, and J. Törnblom. 2015. Barriers and bridges for Sustainable Forest Management: The role of landscape history in Swedish Bergslagen. In: Kirby, K.J. and Watkins, D. (eds.) Europe's changing woods and forests: from wildwood to cultural landscapes. CABI, Wallingford pp. 290-305.

Chiasson, G., P. Angelstam, R. Axelsson, and F. Doyon. 2019. Towards collaborative forest planning in Canadian and Swedish hinterlands: Different institutional trajectories? Land Use Policy 83:334345.

Elbakidze, M., P. Angelstam, T. Yamelynets, L. Dawson, M. Gebrehiwot, N. Stryamets, K.E. Johansson, P. Garrido, V. Naumov, and M. Manton. 2017. A bottom-up approach to map land covers as potential green infrastructure hubs for human well-being in rural settings: a case study from Sweden. Landscape and Urban Planning 168:72-83. 


\section{Austria: Vorarlberg, Montafon}
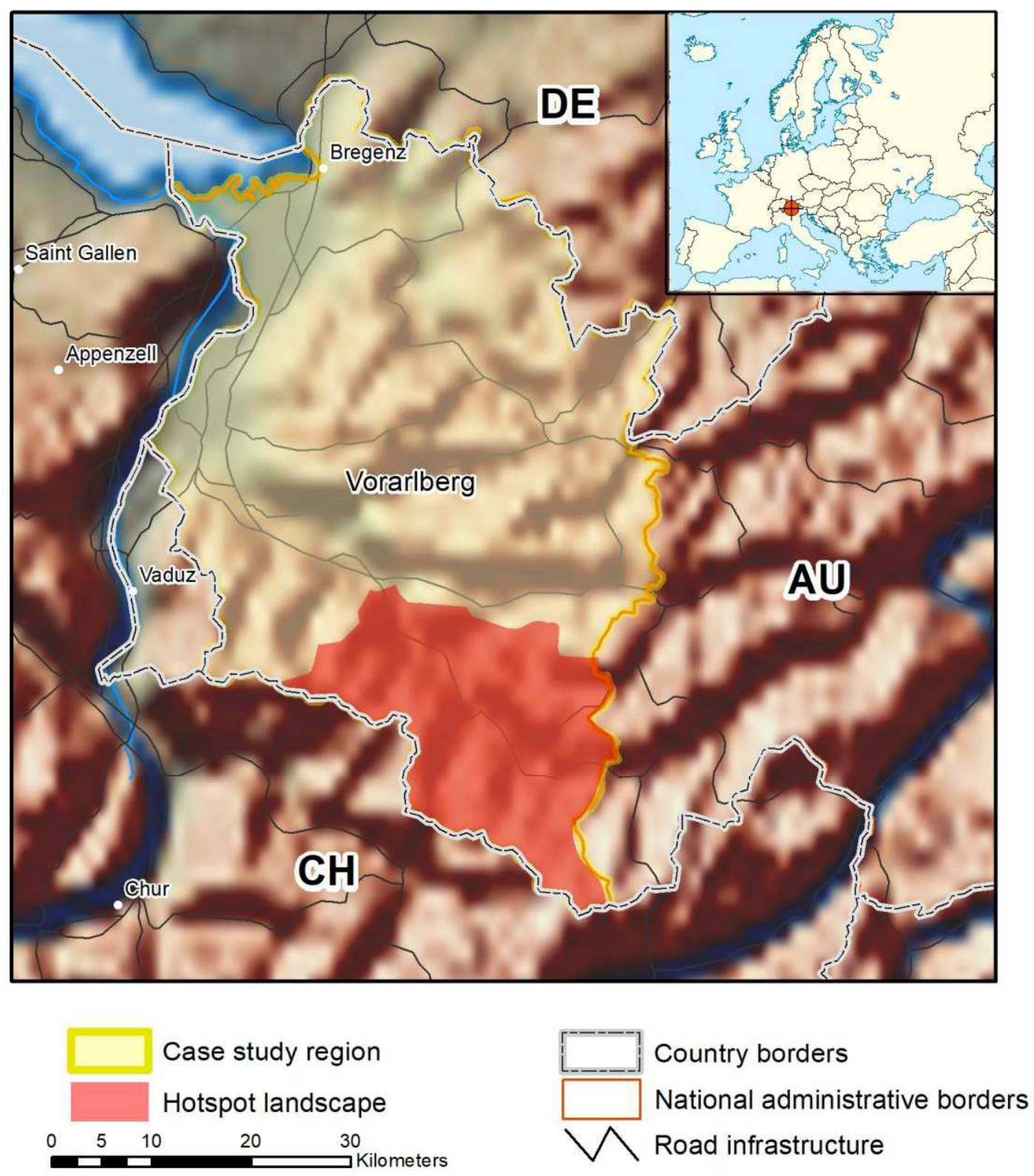

Summary of case study region and hotspot landscape

Due to their terrain and climatic conditions mountain forests have often been protected against deforestation (Sarvašová et al. 2014). A good example is Vorarlberg, which is the westernmost state in Austria, and borders Germany, Liechtenstein and Switzerland. Here there is a steep biogeographical gradient from lowland temperate forest cleared for agriculture and infrastructure, via managed coniferous forests to alpine habitat.

The Montafon valley is located in southernmost Vorarlberg. The valley consists of 10 municipalities covering $563 \mathrm{~km}^{2}$ and with a population of 18,000 , slightly increasing. Montafon hosts a mixture of 
traditional land use like forestry and agriculture as well as energy-production and tourism. There is $7 \%$ agricultural and urban land, 23\% forest reaching $1800 \mathrm{~m}$ a.s.1., $50 \%$ alpine meadows, and 20\% alpine areas. Approximately a third of Montafon is slopes steeper than $45^{\circ}$. In the valley floor, and up to 1000 $\mathrm{m}$ a.s.1., deciduous tree species dominate (Fagus silvatica, Acer pseudoplatanus, Tilia cordata, Fraxinus excelsior) and mixed forests (Picea abies, Fagus silvatica and Abies alba). At >1000 m Picea abies predominate, and locally Larix decidua and Pinus cembra can be found close to the tree-line. Human presence in Montafon is recorded from the Late Neolithic (ca. 3000 BC) onwards (Schmidl et al. 2005). Historically, mining was the most important local industry, and together with processing of copper ores these were important motivations for Bronze Age settlement (Krause 2007)., There is clear increase in forest naturalness with increasing altitude (Angelstam and Dönz-Breuss 2004). Today, $>80 \%$ of forests in Montafon provide essential protection against avalanches, rockfall, landslides and debris flows for villages and infrastructural facilities (Dorren et al. 2004), but also serve for timber production and play an important role for tourism and recreation as well as landscape and nature conservation (Dönz-Breuss et al. 2004). While the number of farmers has declined by $>70 \%$, forestry is still important, employment in the industry and service sectors has grown, and $25 \%$ of the population commutes conveniently to jobs outside Montafon (Loibl and Walz 2010). Tourism is a main source of income in Montafon, which is one of Austria's first tourism regions. Both natural and cultural landscape values are important assets for both residents and tourists (Muri 2001). However, some factors have negative effects on landscapes. First, abundant hydropower plants drive the local population to protest against additional hydropower plants and high-voltage power lines. Second, there is the "Maisäss" cultural landscape with a three elevation-level Alpine transhumance grazing culture. This has transformed formerly forested mid-altitudes slopes into pastures, which are used to feed livestock during spring and autumn, while high altitude pastures free of snow are grazed in summer. The decline of sheep and cattle breeding endangers these pastures. Third, timber production alone is not enough to secure the diversity of forest functions. Additionally, to maintain components of forest biodiversity in managed forests, specific guidelines and target values are needed. Dönz-Breuss et al. (2004) stressed that maintenance and restoration of both natural forest and biocultural biodiversity has to become integral parts of spatial planning. According to Loibl and Walz (2010) tourism is seen as a key element for future regional development in Montafon. This can on the one hand derogate the Alpine region's nature and culture, and is on the other hand threatened by climate change and diminution of landscape attractiveness. The tourism industry does pay for the forest protection services they benefit from (Dönz-Breuss et al. 2004). According to Sarvašová et al. (2014) this indicates deficiencies in inter-sectoral cooperation and governance failure.

\section{Traditional fora}

A good example of a strong network of communities that originally evolved from collective management of landscapes in the Alps is the regional association Stand Montafon (https://standmontafon.at). Since the Middle Ages, the responsibilities of the Stand have changed according to local needs, and today there are three independent associations (Stand Montafon, Stand Montafon Forest Fund and Wastewater Association Montafon) with a common administration. As a regional entity unique in Austria the Montafon association works with management of the valley, and takes on tasks around transport, water treatment, social affairs, forest management, culture, hunting management, tourism, education and business as well as conservation of natural and cultural landscape structures and functions (Dorren et al. 2004). Festivities around the practice of transhumance, and the church are other fora. Persons who are members of a church or religious community are better cared for in times of crisis and have more confidence in persons and institutions (Denz and Battisti 2005). 


\section{New fora}

Studies on the Montafon can be considered a model about the conservation of the "lebensraum" of the local population and the creation of tourism (Lichtenberger 1984). Actual participation of all interested parties, including the local and regional authorities, and the priority of the local population, is on both the local and regional planning levels. Through the EU LEADER programme project Gauertaler Alpenkultur, guests and locals learn about the cultural landscape. Knowledge of how this has emerged is slowly being lost. Therefore, a path was created in the Gauertal as an example of the local alpine culture and transhumance. This also steers hikers away from sensitive areas. In search of a regional presentation with regional product with great charisma, Tschofen (2017) showed how a dairy product, the Montafon Sour Milk Cheese can acquire positive status and embody both tradition and healthy living. The protection of product brands can thus lead to strengthening of regions. However, collaboration to make local products visible in the stores need to be improved (Hambrusch 2011).

\section{Virtual fora}

According to Denz and Battisti (2005) virtual networks have a high priority for maintenance of social capital: the telephone for the elderly, mobile phones and PC-based communication among the younger.

\section{Summary related to social capital framework}

Denz and Battisti (2005) reviewed the development of social capital in the Vorarlberg region, and found that regional identification and life satisfaction was very high in all areas (happiness, work, life, health). They noted that the social network is still very strong. Few live alone and people have friends and acquaintances that they rely on. About $60 \%$ are members of associations, but less young people. Getting new experiences for the younger, and sense of duty for the older, were the reasons for engagement in social fora. Confidence in state institutions, civil servants and parties was not great, and declined towards higher levels of governance. To conclude Denz and Battisti (2005) showed that both bonding and bridging social capital were well developed at the local level, and that there were positive correlations between the quality of the social network and the life satisfaction. However, linking capital across levels of governance was limited.

\section{Literature cited}

Angelstam, P., and M. Dönz-Breuss. 2004. Measuring forest biodiversity at the stand scale - an evaluation of indicators in European forest history gradients. Ecological Bulletins 51: 305-332.

Denz, H., and M., Battisti. 2005. Sozialkapital in Vorarlberg. Studie im Auftrag des Büro für Zukunftsfragen, Amt der Vorarlberger Landesregierung, Fachhochschule Vorarlberg, Dornbirn (verfügbar unter: http://www. vorarlberg. at/pdf-/sk_studie05_endfassung. pdf).

Dönz-Breuss, M., B. Maier, and H. Malin. 2004. Management for forest biodiversity in Austria - the view of a local forest enterprise. Ecological Bulletins 51:109-115.

Dorren, L., F. Berger, A.C. Imeson, B. Maier, and F. Rey. 2004. Integrity, stability and management of protection forests in the European Alps. Forest Ecology and Management 195(1-2):165-176.

Hambrusch, J. 2011. "Local food" from the processors' and retailers' point of view: A case study of Western Austria. Rural Areas and Development, 8: 33-46.

Krause, R. 2007. The prehistoric settlement of the inneralpine valley of Montafon in Vorarlberg (Austria). Preistoria Alpina 42: 119-136.

Lichtenberger, E. 1984. Geography of tourism and the leisure society in Austria. GeoJourna, 9(1):4146.

Loibl, W., and A. Walz. 2010. Generic regional development strategies from local stakeholders' scenarios-an alpine village experience. Ecology and Society 15(3):3. 
Muri, G. 2001. "The World's Smallest Village": Folk Culture and Tourism Development in an Alpine Context. Traditional Dwellings and Settlements Review 13(1):53-64.

Sarvašová, Z., E. Cienciala, J. Beranová, M. Vančo, A. Ficko, and M. Pardos. 2014. Analysis of governance systems applied in multifunctional forest management in selected European mountain regions. Forestry Journal 60(3):159-167.

Schmidl, A., W. Kofler, N. Oeggl-Wahlmüller, and K. Oeggl. 2005. Land use in the eastern Alps during the Bronze Age-An archaeobotanical case study of a hilltop settlement in the Montafon (Western Austria). Archaeometry 47(2):455-470.

Tschofen, B. 2017. Sura Kees. An Alpine Nutritional Relic as a Ferment of Regionality. In: Sarah May, Katia Laura Sidali, Achim Spiller, Bernhard Tschofen (eds.) Geographical Indications as Cultural Property. Göttingen Studies in Cultural Property 10:119-128. 


\section{Ukraine/Romania: Bukovyna region, Putyla district}

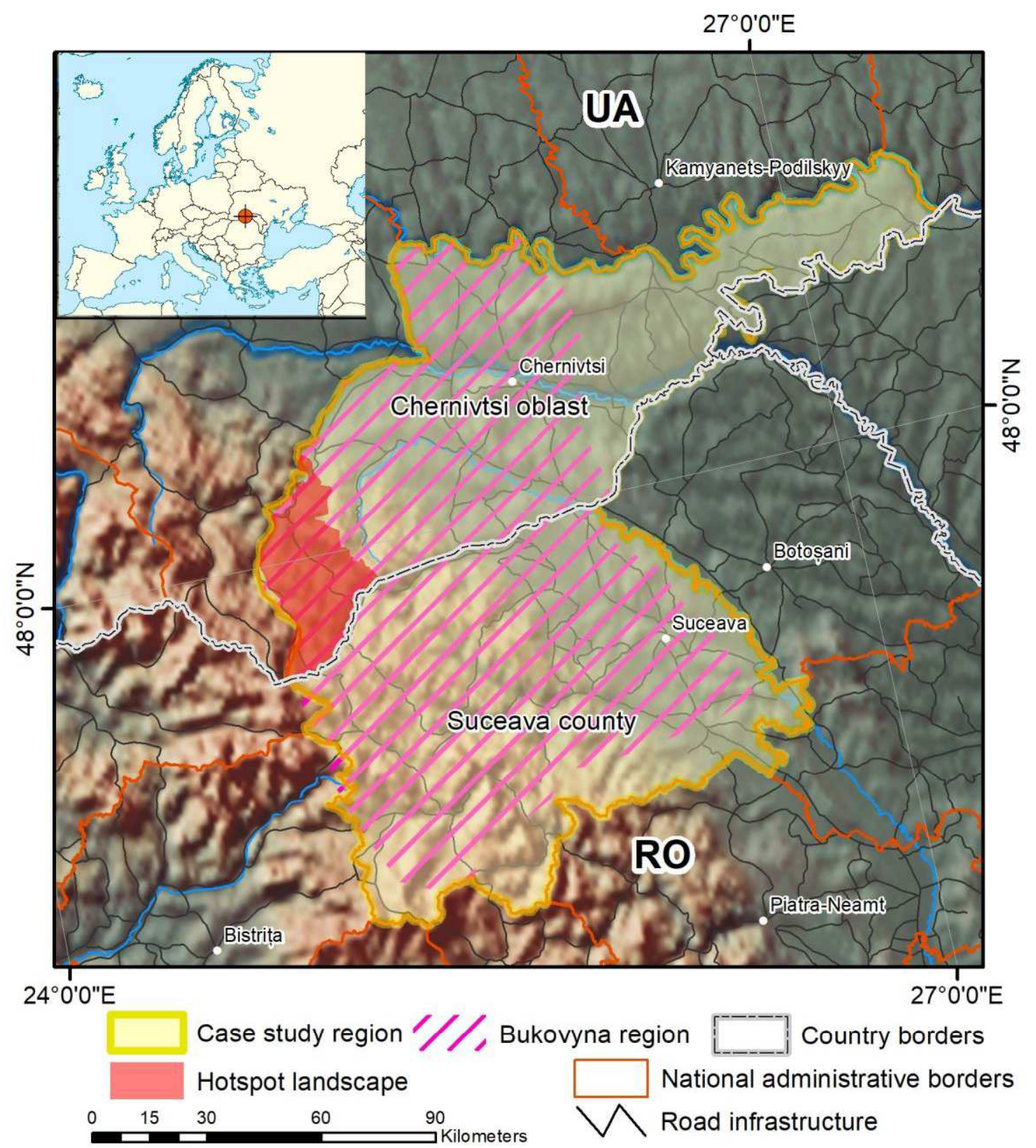

Summary of case study region and hotspot landscape

Bukovyna is a historical region, today divided between the westernmost part of Chernivtsi region in Ukraine and the northern part of the Suceava region in Romania (Vermenich 2013). People settled this territory from the end of the early Paleolithic (12 thousand years BC) in the Dnister river valley (Gerenchuk 1978). In the middle of the Neolithic (3rd - 4th centuries BC) forest covered 80-85\%. By the 18th century the forest area declined markedly. In 1845, when Bukovyna belonged to AustroHungarian Empire, state forests were sold to private owners, and were exported intensively. During the Soviet period forest cover was $30 \%$, but with large difference between mountains and lowlands. A complex history under different governance systems, e.g. Austro-Hungarian Empire, kingdom of 
Romania, the Soviet Union, has formed unique multiculturalism in land use and traditions in Bukovyna. During the Habsburg period (1774-1919) Romanian, Ruthenian (=Ukrainian), German and Jewish communities were represented in governance (van Drunen 2013). The Austro-Hungarian Empire law on tax-free income encouraged population growth. In 1944, the Bukovyna was split between Romania and Ukraine as a part of the Soviet Union. This totalitarian regime's efforts to destroy religion was one of the main factors of maintaining people's Soviet identity (Bodnar 2015).

The Putyla district is located in the westernmost part of Ukraine's Chernivtsi region along the border with Romania, and near the source of the White Cheremosh River. It has poor road infrastructure and limited regional economic development. This district is part of the cultural rural region Hutsulshchyna, which is considered to be the least modified region of the cultural landscapes in the Carpathian Mountain range (Kibych 2010, Chervinska et al. 2017). This is driven by its cultural heritage and remoteness. The traditional types of land management are associated with forestry, sheep and cattle breeding for meat and dairy production. About $63 \%$ of the district's area is covered with forests, dominated by Norway spruce (Picea abies), fir (Abies alba) and beech (Fagus sylvatica). Livestock grazing has a seasonal transhumance character on mountain pastures. Small scale cultivation of agricultural product (potatoes, corn, carrots), beekeeping, harvesting of hay and fuel wood are key livelihood components. During the Soviet period, cultivated pastures were developed for collective farms. After their collapse, no measures for the cultivation of pastures have been implemented. This contributes to the regeneration of forest on agricultural land. After the post-Soviet economic crises a wool-processing plant that employed more than 600 people was closed, leading to a decrease in the number of sheep in the region. Self-subsistence farming dominates, while the forestry sector still is the main source of employment through harvest, transport and small-scale wood processing facilities.

\section{Traditional fora}

Like in remote rural regions in general (Zhuk and Demedyuk 2018), the village is a key socialecological unit in the Putyla district. For local people, the church, traditional village councils and libraries were and still remain key meeting points. Traditional church holidays, when people from neighbouring villages come to meet, are increasingly important. This also includes ethnographic events such as the annual spring festival "Exit to the Polonyny" celebrating the seasonal migration of livestock and sheep to high mountain meadows, and the Hutsul people craft of producing traditional carpets, and use of non-wood forest products (Kibych 2010). The primary assets include both natural and cultural landscapes, cultural heritage values associated with local folklore, customs, handicrafts, and other elements. These values are a strong basis for development of various forms of tourism, in particular ethnotourism (Kibycz and Parzych 2012, Romaniv and Man'ko 2013, Khovalko 2015, Buchko et al. 2016).

\section{New fora}

Today, some initiatives to establish new jobs dealing with outdoor recreation and nature-based tourism, biodiversity and wilderness conservation are taking place. The most prominent effort is the creation of the Cheremosh National Nature Park $\left(71 \mathrm{~km}^{2}\right)$ in 2009 (Bacal et al. 2016). Efforts to establish crossborder Ukrainian-Romanian protected areas are taken based on international conservation policy (Getman 2015). In last decades about 30 hotels and restaurants to support green tourism were built, and services were also provide in private houses (Romaniv and Man'ko 2013). Small firms like the resort "The quiet farmstead" are promoting ecotourism in the area. At collecting points for berries and mushrooms locals can sell their harvested forest goods to get their main or additional income, and a milk-processing facility buys milk from locals. 


\section{Virtual fora}

Despite the short distance to the regional capital of Chernivtsi $(120 \mathrm{~km})$, due to the very bad road quality and poor transport infrastructure commuting between villages is hampered. To highlight this issue and improve road quality the internet has been used to connect the local level of Putyla district with regional and national levels of governance.

\section{Summary related to social capital framework}

Emigration to richer regions of Ukraine and abroad to Poland, Italy and Czech Republic, as well as labour migration especially of women that leave for Western Europe where they work offering different services, has been the main demographic trend in rural regions for more than the past 20 years (Kibych, 2010). Hence, supporting and maintaining all forms of social capital is urgent. However, the number of people who recognize traditions as important ones in their lives is decreasing (Chervinska et al. 2017). Zhuk and Demedyuk (2018:51) concluded that "Obviously, the development of rural mountain territories economy is doomed to retardation and their social and economic situation will not escape depressiveness in the absence of preferential mechanisms, adoption of relevant state programs for their development and participation in the European technical assistance and territorial cooperation programs." Alternatively, according to Sarkki et al. (2019) "Transition processes need to go "beyond participation" by (i) legal reforms to better acknowledge ES (Ecosystem Services) important for local people, (ii) a change from an exclusive focus on timber to acknowledging multiple $E S$, (iii) changed spatial and temporal rationales of state-based governance, and (iv) recognition of local people as credible experts." Social innovations that foster social capital need to pay attention on how the novel fora can be sustained after the project period, and how their approaches disseminated and scaled up. Otherwise social innovation projects will remain local curiosities. Building on hutsul traditional culture is a main factor that can maintain and strengthen social capital (Chervinska et al. 2017).

\section{Literature cited}

Bacal, P., I. Moroz, and P. Bunduc. 2016. The tourism potential in the Ukrainian sector of the Prut River basin and its problems of promotion and exploitation. Lucrările Seminarului Geografic "Dimitrie Cantemir" 42: 135-144.

Bodnar V. 2015. The soviet regime repression against orthodox church in Bukovyna region in 19401960s. Modern Science (Moderní věda) 3. 65-72.

Buchko, Zh., S. Rudenko, V. Rudenko, and H. Yeremiia. 2016. Ethnic tourism potential of Bukovyna for the purposes of cross-border tourism. Часопис сочіально-економічної географії випуск 20(1):65-79.

Chervinska, I., J. Nykorak, and A. Chervinskyi. 2017. The traditions and beliefs of highlanders as a means of self-identity and ethnos preserving. Journal of Vasyl Stefanyk Precarpathian National University 4(1): 79-86.

Gerenchuk, K.I. (Ed.) 1978. Nature of Chernivtsi region. Lviv: High School Press. 160 р. [Природа Чернівецької області / [під ред. Геренчука К. І.] - Львів : Вища школа. - 1978. - 160 с.]

Getman, V. I. 2015. National Natural park "Cheremoskyy" and Biosphere Reserve "Maramoroskyi mountains". Scientific journal «Biological systems: theory and innovation» 214:71-82.

Kibych (Czaplińska), A. 2010. Hutsulshchyna and public progress. Bulletin of Geography, Socioeconomic Series 14:37-50.

Kibycz (Czaplińska), A.D., and K. Parzych. 2012. The perception of the main determinants of tourist attractiveness of Hutsulshchyna in the opinion of its inhabitants. Geography and Tourism УДК 338.48.- 6:39(447.8): 133-139. 
Khovalko A. 2015. European integration opportunities of Ukrainian tourism and recreation development. Geographical information Ročník 19 (1):40-47.

Romaniv P., and A. Man'ko. 2013. Factor and resource preconditions of tourism organization in Putylskyi district of chernivtsi region. Visnyk of the Lviv University. Series Geography 42:298-305.

Sarkki, S., T. Parpan, M. Melnykovych, L. Zahvoyska, J. Derbal, N. Voloshyna, and M. Nijnik. 2019. Beyond participation! Social innovations facilitating movement from authoritative state to participatory forest governance in Ukraine. Landscape Ecology 34(7):1601-1618.

van Drunen, H.F. 2013. «A sanguine bunch». Regional identification in Habsburg Bukovina, 17741919. PhD thesis, University of Amsterdam. (https://pure.uva.nl/ws/files/1531434/126251 thesis.pdf)

Vermenich, Ya. V. 2013. Chernivtsi Region [Electronic resource] // Encyclopedia of the History of Ukraine: Volume 10 / Ed. V.A. Smoliyet.al, NAS of Ukraine. Institute of History of Ukraine. Kyiv: Scientific Thought Press, 688 p. Accessed 2019-11-07 at http://www.history.org.ua/?termin=Chernivetska_oblast Верменич Я.В. 2013. Чернівецька область [Електронний ресурс] // Енциклопедія історії України: Т. 10 / Редкол.: В. А. Смолій (голова) та ін. НАН України. Інститут історії України. - К.: В-во "Наукова думка", 688 с. Zhuk, P., and O. Demedyuk. 2018. Ways of economic development intensification in the rural mountain areas of Ukraine. Agricultural Economics and Rural Development, New Series XV(1):4351. 


\section{Georgia: Kakheti region, Tusheti province in Akhmeta municipality}

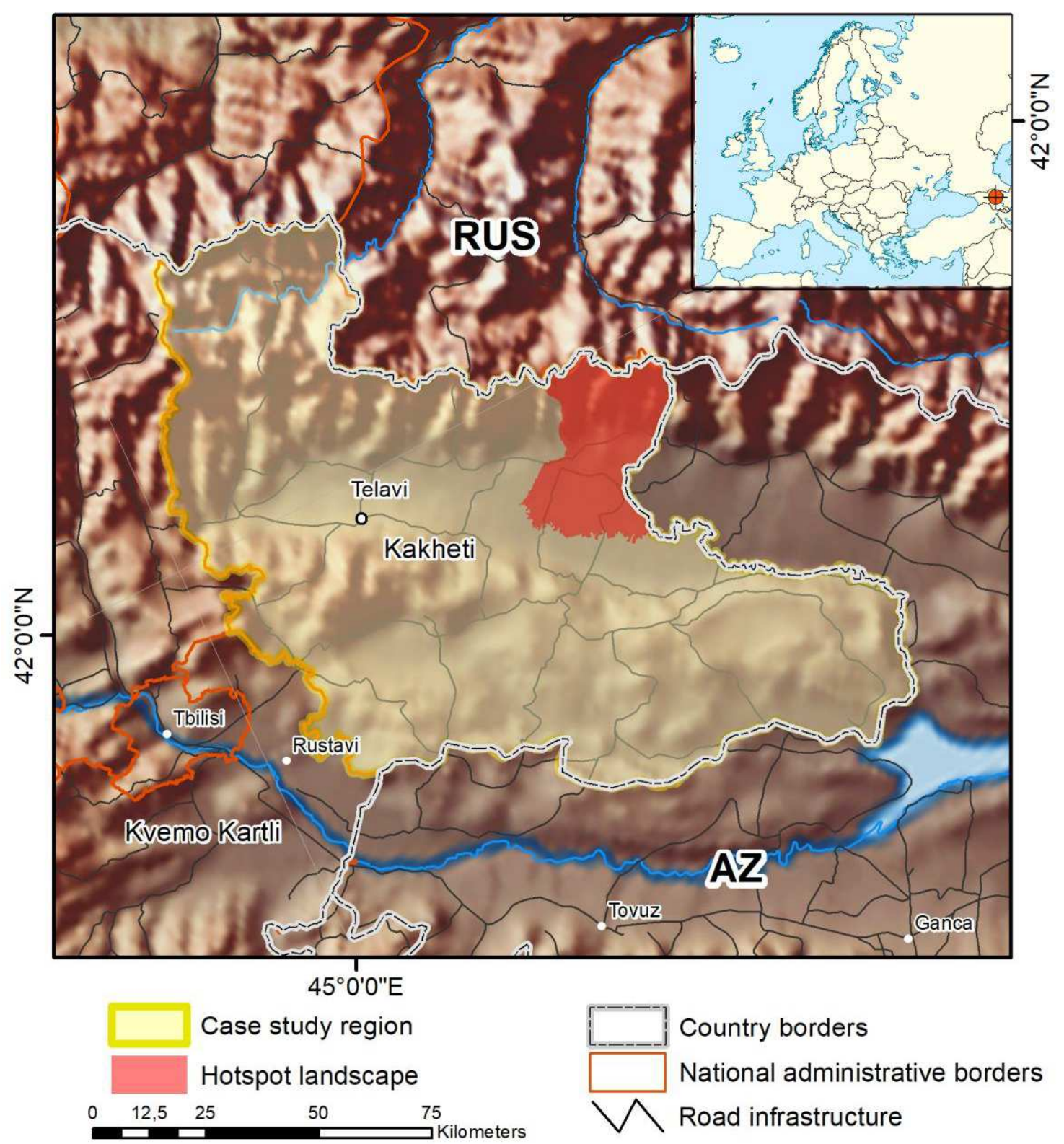

\section{Summary of case study region and hotspot landscape}

Located in the economic periphery of the European continent, and thus with a relatively lower than usual anthropogenic pressure on landscapes, Georgia hosts remnants of both intact natural biodiversity in forests and mountains as well as traditional cultural landscapes. These serve as important habitat for in situ conservation of natural and cultural heritage, and as benchmarks for the functionality of different types of green infrastructure elsewhere. At the same time, Georgia is one of transitioning countries that has challenges in political, economic and social spheres. Improvements are indicated by trends in indicators like perceived corruption and democracy. As a case study region, we chose the Kakheti region in eastern Georgia. It was formed in the 1990s by merging the historical province of Kakheti and 
the mountainous small province of Tusheti. Originally an independent unit from the late eighth century, four centuries years later, Kakheti became part of the Georgian Kingdom. After its disintegration and a period of independence, Kakheti came under intermittent Iranian rule, and was annexed to the Russian Empire in 1801. In 1918-1921 Kakheti was part of the independent Democratic Republic of Georgia, in 1922-1936 part of the Transcaucasian SFSR and in 1936-1991 part of the Georgian SSR. Since 1991, Kakheti has been a region in Georgia.

Akhmeta (Georgian: sbdวơs) municipality in Kakheti forms a steep gradient in altitude, vegetation and land use types from the plains of the Alazani river in the south to the Caucasus Mountains in the north, which is one of the world's 34 Biodiversity Hotspots (Zazanashvili and Mallon 2009). The lowlands in the south once hosted oak forests, since long transformed for crop production and vineyards.

Monuments of nature like the yew tree "Patriarch "in Akhmeta (ca 1,800 yrs old) and remnant large solitary oaks are witnesses of past forests (Green Alternative 2007). The majority of farmers rely on livelihoods from small parcels (median $<1$ ha) of family farmland. State pensions, and financial aid provided by friends or relatives, are the primary monetary incomes (Forkel 2009). There is considerable disparity between lower incomes in rural than in urban households. Wine making is the main value-added business. Increasingly, agro tourism is a sustainable livelihood strategy, which supports winemakers' livelihoods (Tamarashvili and Burdiashvili 2016, Kresse 2017). The highland province Tusheti in the north is one of the richest regions of Georgia in terms of plant and animal species diversity, and has conserved ancient traditions of the alternate-pasture farming culture focused on sheep breeding involving seasonal movement between highlands and lowlands (Kavtarishvili 2015, Mühlfried 2010). The large number of sheep in Kakheti compared to the rest of Georgia is linked to presence of both summer and winter pastures (Allahverdiyeva 2019). Tushetian mobility in space is thus consistent with the general criteria of transhumance. The pastoral culture has created a traditional cultural landscape mosaic of small settlements, fields, hay meadows, pastures and forests. The forests habitats in Tusheti are dominated the pine species Pinus kochiana at lower altitudes, and birches (Betula pendula, B. litwinowii, B. raddeana) at 1,700-2,400 m. With high mountains and forests, old villages and castles, Tusheti is attractive for visitors. The resident population in Tusheti has dwindled severely (Tsitsagi and Kvirkvelia 2019). Today, Tushetians spend winter in three lowland villages in in Akhmeta municipality (Zemo Alvani, Kvemo Alvani and Laliskuri, where a large part of the population are Tushetians). The summer population in Tusheti is 2,000-2,500 people, but only 20-40 individuals stay there throughout the year (Kavtarishvili 2015). In recent years implementation of various local or international projects on tourism development has had a major impact. To improve livelihoods and income, Tsitsagi and Kvirkvelia (2019) stressed the need for informing tourists about local traditions, conservation of natural and cultural diversity, use of culture and respect for local traditions.

\section{Traditional fora}

According to Mühlfried (2010) "Tushetians economic, military, and socio-political strength enhances the potential for negotiations with the state and turns the Tushetians into citizens with not only duties, but also rights and privileges." Religious annual festivals (Tushetian: atnigenobebi) and the shulta ("organizer of a saint's festival, whose obligation is to feed the people on this day") were traditional meeting places. The transhumance system is associated with a semi-autonomous life of individual family members, including a relatively strong position of women in the family and the public (Mühlfried 2010:190). However, during the Soviet period forced sedentarization of "nomadic" societies aimed at providing workers for industrialization, and to control those who were difficult to handle politically and administratively; and refusing to become sedentary meant loss of claims to pasture land in the plains. Insufficient supplies of food and fuel was another driver, and by the 1950s 
most Tushetians left the mountain villages, and settled in the wine-growing areas on the plains (Kvemo Alvani, Zemo Alvani, Laliskuri) (Mühlfried 2010).

\section{New fora}

Tusheti protected areas have become a showcase for the establishment of protected areas (Kavtarishvili 2015). This includes both the Tusheti Protected Landscape (IUCN category V), which is managed by the local self-governmental body of Akhmeta municipality, and Tusheti protected areas, consisting of the Tusheti strict nature reserve (IUCN category I,) and the Tusheti national park (IUCN category II,), managed by the Protected Areas Agency of Georgia through its territorial administration - the Tusheti protected areas administration. With numerous settlements the objective of the Tusheti Protected Landscape is nature conservation, and to maintain the cultural landscape, which is the result of interactions between nature and culture, and to develop recreational use (Georgian Law No 2086-Is, 22/04/2003). Tushetians are represented in the local self-government of Akhmeta municipality, and together with the other residents of the Akhmeta municipality, elect the head of the local executive board. With the director, key staff and rangers being Tushetians, the local community is well represented in the management of the Protected Landscape. The Tusheti Protected Landscape hosts the first example of communal forestry in Georgia (Machavariani, 2014). In general, municipalities do not have the capacities to manage natural resources, but after designating the Tusheti PL and assigning Akhmeta municipality as its manager, the municipality established the Tusheti protected landscape administration. However, due to the lack of knowledge and capacities, it took Akhmeta eight years to establish the administration, and only after 2014 the signs of real management appeared there. Regarding livelihood farming, Forkel (2009) observed severe barriers establishing bottom-up strategies, partly because of the centralized government structure in Georgia and a rural mindset that considers the government be responsible, meaning that communities do not engage.

\section{Virtual fora}

Nowadays local communities of Tusheti actively use different channels and platforms for exchanging information, communication with each other, as well as with people from other communities. There are several social media channels developed by Tushetians, which are used for different purposes (awareness raising about Tusheti, tourist attraction, discussion of different topics related to Tusheti, informing and virtually involving Tushetians who live in other cities/countries about local issues and processes). Thus, next to traditional and cultural means of communication virtual communities are gradually becoming more and more popular. Digital media and modern technologies seem to be easier ways to communicate, especially when considering that Internet connection is available in Tusheti, even in the areas where there is no GSM coverage.

\section{Summary related to social capital framework}

The effectiveness of traditional, novel and virtual fora is depending on the constituent level and types of social capital (Ferragina 2012). Human well-being outcomes of Tusheti is strongly linked with expanding the quality and quantity of: (i) bonding social capital, meaning that Tushetians living in each of the villages or even gorges of Tusheti (there are 4 gorges in Tusheti), that combine several villages shares common interests, local rules, culture and traditions among each other; (ii) bridging social capital, meaning interaction in Tusheti is between the communities from the four gorges. In this context, Tushetians are able to access and use each other's social network resources. In this process locals share many norms and trust; and (iii) linking social capital - a vertical interaction with the actors/institutions, where norms of respect and networks of trusting relationships are introduced. The above mentioned applies to the local actors and stakeholders from Tusheti, the Akhmeta municipality and the vertical level stakeholders/institutions. 


\section{Literature cited}

Allahverdiyeva, N. 2019. Socio-economic analysis of farming households in the case study villages of Azerbaijan and Georgia. Technical Report, DOI: 10.13140/RG.2.2.22677.78566

Didebulidze, A., and Plachter, H. 2002. Nature conservation aspects of pastoral farming in Georgia. In Pasture landscapes and nature conservation (pp. 87-105). Springer, Berlin, Heidelberg. https://link.springer.com/chapter/10.1007/978-3-642-55953-2_6

Ferragina, E. 2012. Social capital in Europe: A comparative regional analysis. Edward Elgar Publishing, Cheltenham.

Forkel, B. 2009. Agriculture and the social economic situation of the rural population in Georgia: a case study focusing on the Kakheti-region. Journal of Central European Agriculture, 10(1), 27-32.

Gigashvili, K., G. Gotsiridze and A. Bertlani. 2020. Social-Economic, Ethno-Cultural and Linguistic Outcomes of Migration (with the Example of One Georgian Village). ceeol.com 1: 102-111

Goguadze, G., and Kapanadze, S. 2015. Daesh and challenges facing Georgia. Georgian foundation for strategic and international studies 87

Green Alternative 2007. Protection and Management of Biodiversity in Georgia. Retrieved at http://www.greenalt.org/webmill/data/file/biodiversity_final.pdf

Hauk, B., and B. Rentz. 2019. Tsova-Tush language attitudes and use. scholarspace.manoa.hawaii.edu

IUCN Caucasus Cooperation Center. 2014. Forest Management in Tusheti Protected Landscape. (retrieved from http://www.enpifleg.org/site/assets/files/2080/forestmanagementintushetiprotectedlandscape iucnccc.pdf)

Kavtarishvili, M. 2015. Tusheti and its forests-a unique case of local governance in Georgia. eco. mont-Journal on Protected Mountain Areas Research 7:70-77.

Kresse, T. 2017. Agritourism as a specific sustainable livelihood strategy in the Kakheti region: An examination of impacts from agritourism on local small-scale winemaker's livelihoods and its sustainability. http://www.diva-portal.org/smash/record.jsf?pid=diva2\%3A1118401\&dswid=9202

Kruwinus, R., A. Salzer, and J. Etzold. 2019. Final Report of the project Assessment of Pasture Condition in Sagarejo Municipality, Georgia.

Lomsadze, Z., K. Makharadze, M. Tsitskishvili, and R. Pirtskhalava. 2017. Water resources of Kakheti and ecological problems. Annals of Agrarian Science 15(2):204-208.

Machavariani, M. 2014. Opportunities and Challenges for Communal Forestry in Georgia. On the case of Tusheti Protected Landscape. (retrieved from http://www.enpifleg.org/site/assets/files/2154/opportunities_and_challenges_for_communal_forestry_in_georgia activity 5 4.pdf)

Meladze, M., and G. Meladze. 2017. Climate Change: a trend of increasingly frequent droughts in Kakheti Region (East Georgia). Annals of Agrarian Science 15(1):96-102.

Meladze, G., and M. Meladze. 2016. Influence of Global Warming on Agroclimatic Indices of Agriculture and Intensity of Droughts in Kakheti Region, East Georgia. Bull. Georg. Natl. Acad. Sci, 10(1):97-104.

Mühlfried, F. 2010. Did communism matter? - settlement policies from above and below in highland georgia. In: Cultural paradigms and political change in the Caucasus: collection of essays (pp. 174196). Lap Lambert Academic Publishing.

Sanikidze, G. 2007. Islamic Resurgence in the Modern Caucasian Region:" Global" and" Local" Islam in the Pankisi Gorge (pp. 263-282).

Siprashvili, N. 2014. Islamic Revival in Georgian-Chechen Border Area (Master's thesis, The University of Bergen).

Tamarashvili, T., and M. Burdiashvili. 2016. Wine Tourism Aspects of Kakheti. Tourism Education Studies and Practice 8(2):58-62. 
Tsitsagi, M., and Kvirkvelia, N. 2019. Some Demographic Trends in Borderline Regions of East Caucasus Mountains (Georgia). Ankara Üniversitesi Çevrebilimleri Dergisi 7(2):125-129.

Tsulaia, I. 2011. To be Kist: Between Georgian and Chechen. Changing Identities: Armenia, Azerbaijan, Georgia, 126 pp.

Tsutskiridze, D. 2002. Georgia's Pankisi gorge. Religion and conflict. In: Cifu, I., O. Popescu, and B Nedea (eds.). Religion and conflict: Radicalization and violence in the wider Black Sea region, $\mathrm{p}$. 373-380.

Wiktor-Mach, D. (2009). Competing islamic traditions in the Caucasus. Caucasian Review of International Affairs 3(1):63-69.

Zazanashvili, N., and D. Mallon (Eds.). 2009. Status and Protection of Globally Threatened Species in the Caucasus. Tbilisi: CEPF, WWF. Contour Ltd., 232 pp. 


\section{Turkey: Mersin and Karaman provinces, Gülnar oak woodland}

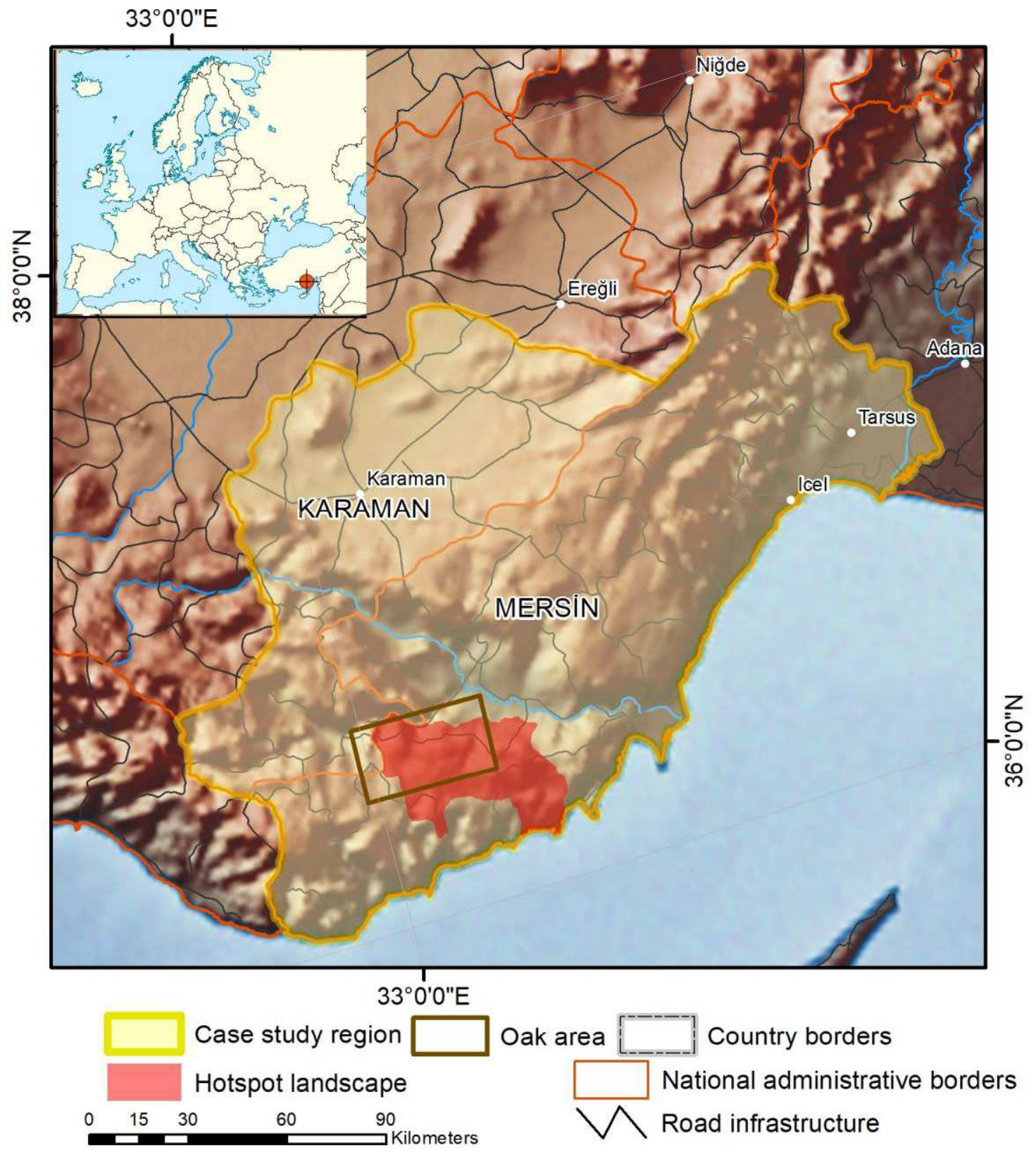

Summary of case study region and hotspot landscape

The Turkish Mersin Province is located between the Mediterranean coast and the Taurus Mountains, and is bordered to the north by the Karaman province on a high arid plain. The vegetation zones range from Mediterranean shrub and Turkish pine (Pinus brutia) forests at lower altitudes to oak woodlands and mountain coniferous forests (Duran 2012). North of the Taurus Mountains steppe vegetation dominates (Atalay 1988, Atalay et al. 2014). Mersin is part of Çukurova, a geographical, economic and cultural region in southern Turkey with an ancient history of natural resource use (Colak and Rotherham 2006). This case study area forms a steep rural-urban gradient from remote upland villages practising traditional subsistence farming and animal husbandry to lowland areas with heavy industrial, 
trade and tourism development, and intensive food production on the alluvial coastal plains (Duran et al. 2012, Levent 2016).

Locally, representing an endangered type of traditional cultural landscape in Europe, pollarded trees mainly consisting of oaks (Quercus ithaburensis macrolepis) are abundant. This woodland with trees up to 600 years of age has paramount biocultural value. Located in the NW corner of the Mersin province, the surroundings of the Köseçobanlı village with 2626 inhabitants in the Karınbeleni region is a good example. Here oak woodlands cover $292 \mathrm{~km}^{2}$ with approx. 730,000 trees. One of the core areas for oak pollards is estimated to contain around 50,000 old hollow pollards in an area of $50 \mathrm{~km}^{2}$. This is one of the largest concentrations of old pollards in the world. This area is also situated in one of the hotspot regions in Turkey for endemic plants (Ekim et al. 2000). Recent studies of the oakwood habitat have revealed a very rich woodpecker fauna and a unique saproxylic beetle fauna (Bergner et al. 2016, Jansson et al. 2016, 2018). The oaks are managed by Yörük (nomadic) people's seasonal transhumance involving regular cutting of the twigs in the late summer to give as fodder to goats and sheep when most ground vegetation is grazed or has dried out in the summer. The dried twigs are also used as firewood. This can be observed in the Kösecobanli oak landscape in Gülnar municipality. This type of tree management constituted an important base of the life for a goat herding nomad people for a long time (Kavas and Bakir 2015). Still there are hundreds of families living at low altitude near the Mediterranean Sea during the winter, but in early spring they start a long slow walking journey with their goats and sheep up to the plateaus in the mountains. Often the summer grazing areas are situated at 1200-1700 m a.s.l. The walk with herds can take several months and they arrive in July for grazing, and to start the pollarding of oaks. Today, however, most of the region is instead used by settled villagers, often previous nomads, producing different crops such as barley, apples and almonds. The area consists of a mixture of small coniferous forest patches, fields and grazed oakwood areas. The new forest management plan for the period 2016-2025 has set aside roughly one-thirds of this old oak area partly as strict conservation forest and partly as limited-management forest area. The old oaks are supposed to be conserved in these allocated conservation priority forest areas according to the new forest management plans. For the rest of the old oak woodland, the plan states that timber production will take place cutting down old oaks, which is considered to be degraded forest, and replacing them with conifer plantations.

\section{Traditional fora}

Village councils, coffeehouses, traditional open markets and family events like marriages and funerals, as well as Friday prayers in mosques, religious and official holidays are the important meeting points. Forest practise and its related works in the districts are carried out through the directorates of state forest enterprises. Animal husbandry and agricultural operations are carried out through the state's agriculture and animal husbandry directorate. To inform the local people, meetings are held by the government officials in the village centres on various subjects. There is a network of speakers in the region where various advertisements are announced.

\section{New fora}

In addition to traditional fora, various meetings, festivals, and organizations are organized by the governmental bodies such as Mersin Governorship, Mersin Metropolitan Municipality, Gülnar Governorship, Gülnar Municipality, village councils, and the Agriculture and Forestry Services. The internet and telephone are other important modes of communication. Companies and civil society such as agricultural association, sheep and goat breeders' association, apiculture association, and other NGOs organize various activities. Gülnar Forest Management Directorate was chosen as a pilot site 2014-2018 for the UNDP-GEF (Global Environmental Facility) project called 'Integrated Approach to 
Management of Forests in Turkey, with Demonstration in High Conservation Value Forests in the Mediterranean Region. Within this project most of the western half of the Köseçobanlı oakwood hotspot area was planned as a high conservation value forest with no or limited forestry activities to conserve biodiversity. Another new forum is provided by voluntary forest certification. Mersin Regional Forest Directorate, recently obtained an FSC certificate (Forest Stewardship Council's international certification for responsible forestry). For this reason, free, prior and informed consent of the local people on forestry activities should be more closely followed by the foresters. Additionally, HCVFs (High Conservation Value Forests) should be managed according to preserve their values. The hotspot area is a HCVF area including HCV-1, HCV-3 and HCV-5 categories (Brown et. al, 2013; Taşdemir et. al, 2016).

\section{Virtual fora}

Representatives of various NGOs are active in the region with the aim to create environmental awareness. The Turkish Oak Habitat Project (http://www.turkishoaks.org/) consisting of a large number of Turkish and foreign specialists, is actively advocating the need for conservation of the oak woods in Köseçobanl1. There is one news website (www.gulnarcity.com) for Gülnar sub-province, where the oak forest hotspot area is located. For Mersin villages Rad et al. (2013) showed that for the use of computers and internet, age, gender and the level of education are key factors. Thus smartphone applications have become crucial.

\section{Summary related to social capital framework}

The Yörük life has lost its traditional mobile, flexible and dynamic qualities and has been transformed into oscillation between two static points used in winter and summer. Since the movement between the seasonal points is isolated from environmental factors, the Yörüks lost their traditional abilities to cope with natural difficulties and their profound engagement with the environment (Kavas and Bakir, 2015). Based on meetings with seven villages in the Mersion province Senyaz et al. (2011) concluded that forest-based poverty need to be addressed by other land uses, in particular agriculture, grazing and mixed systems of crop and tree growing. Hence, a multi-sectoral approach is needed and local authorities must be key supporters. A rich cultural heritage, and the mountain and highland landscapes of the district are important for tourism. However, lack of local businesses forces local people to migrate to work places elsewhere. State funding of agriculture and livestock activities can improve social life and rural development. While local bonding social capital within groups appears strong, bridging and linking social capitals both bottom-up need to be strengthened.

\section{Literature cited}

Atalay, İ.,1988. Vegetation levels of the Taurus Mountains of Mediterranean region in Turkey. Ege Coğrafya Dergisi 4(1):88-120.

Atalay, I., R., Efe, and M. Öztürk. 2014. Ecology and classification of forests in Turkey. ProcediaSocial and Behavioral Sciences 120:788-805.

Bergner, A., A. Sunnergren, B. Yeșilbudak, C. Erdem, and N. Janson. 2016. Attributes of trees used by nesting and foraging woodpeckers (Aves: Picidae) in an area with old pollarded Oaks (Quercus spp.) in the Taurus Mountains, Turkey. Zoology in the Middle East http://dx.doi.org/10.1080/09397140.2016.1226242

Brown, E., N. Dudley, A. Lindhe, D.R. Muhtaman, C. Stewart, and T. Synnott (eds.). 2013. Common guidance for the identification of High Conservation Values. HCV Resource Network.

Colak, A. H., and I. D. Rotherham. 2006. A review of the forest vegetation of Turkey: its status past and present and its future conservation. Biology and environment: Proceedings of the Royal Irish Academy 106b(3):343- 354. 
Duran, C. 2012. Mersin ili orman alanlarının fizyografik özelliklereb göre dağılımı (Distribution of forest areas according to physiographic features in Mersin province (South of Turkey).) Journal of Human Sciences 9(1):1-19. (In Turkish).

Duran, C., H. Gunek and E.K. Sandal. 2012. Effects of urbanization on agricultural lands and river basins: Case study of Mersin (South of Turkey). Journal of Environmental Biology 33(2):363-371.

Ekim, T., M. Koyuncu, M. Vural, H. Duman, Z. Aytac, and N. Adigüzel. 2000. Red data book Turkish plants (Ptreidophyta and Spermatophyta) Ankara. Bariscan ofset (In Turkish).

Jansson, N., M. Avcı, T. Kayiş, M. Coşkun, O. Sarikaya, T. Öncul Abacigıl, S. Vural Varlı, S. Tezcan, O. Türkay, A. Sunnergren, F. Aytar, and A. Bergner. 2016. Diversity of birds and beetles on Turkish Oaks (Quercus spp) - important for future silvicultural planning (In Turkish). In proceedings of the "International Oak Workshop" on October 18-20, 2016 in Igneada / Kirklareli / Turkey. P. 95-113.

Jansson, N., O. Türkay, and M. Avc1. 2018. A hidden treasure in Turkey - old oaks with unique values. In: Ancient Woodlands and Trees: A Guide for Landscape Planners and Forest Managers. P 260267. Ed: Colak, A. Publisher: IUFRO.

Kavas, K.R., and I. Bakir. 2015. A Comparative Analysis of the Past and the Present: Plateau Settlements and Semi-Nomadic Life in the Taurus Mountains (Turkey). Athens Journal of Mediterranean Studies 1(3): 235-248.

Levent, T. 2016. RIS-Mersin project: the first regional innovation strategy in Turkey and its spatial dimensions. Acta Universitatis Lodziensis. Folia Geographica Socio-Oeconomica 24:5-16.

Rad, S.T., Ş. Kurt, and S. Polatöz. 2013. Use of Information and Communication Technologies in Rural Mersin(Turkey); Prospects For Rural Development. Journal of Tekirdag Agricultural Faculty 10(3):97-106.

Senyaz, A., M. Sülüsoglu, and E. Yilmaz. 2011. People's Participation in Forest Management and Some Recommendations. The Case Study of Mersin (Turkey). Forêt méditerranéenne XXXII(4):465-469.

Taşdemir, C., A. Abbak, O. Polat, and A. Topal. 2016. Investigation of lack of sprouting in oaks within the degraded oak areas and current silvicultural practices applied. Invertigation Report. East Mediterranean Forestry Research Institute (In Turkish). 


\section{Sharra Mountain Region (North Macedonia, Kosovo*, Albania)}

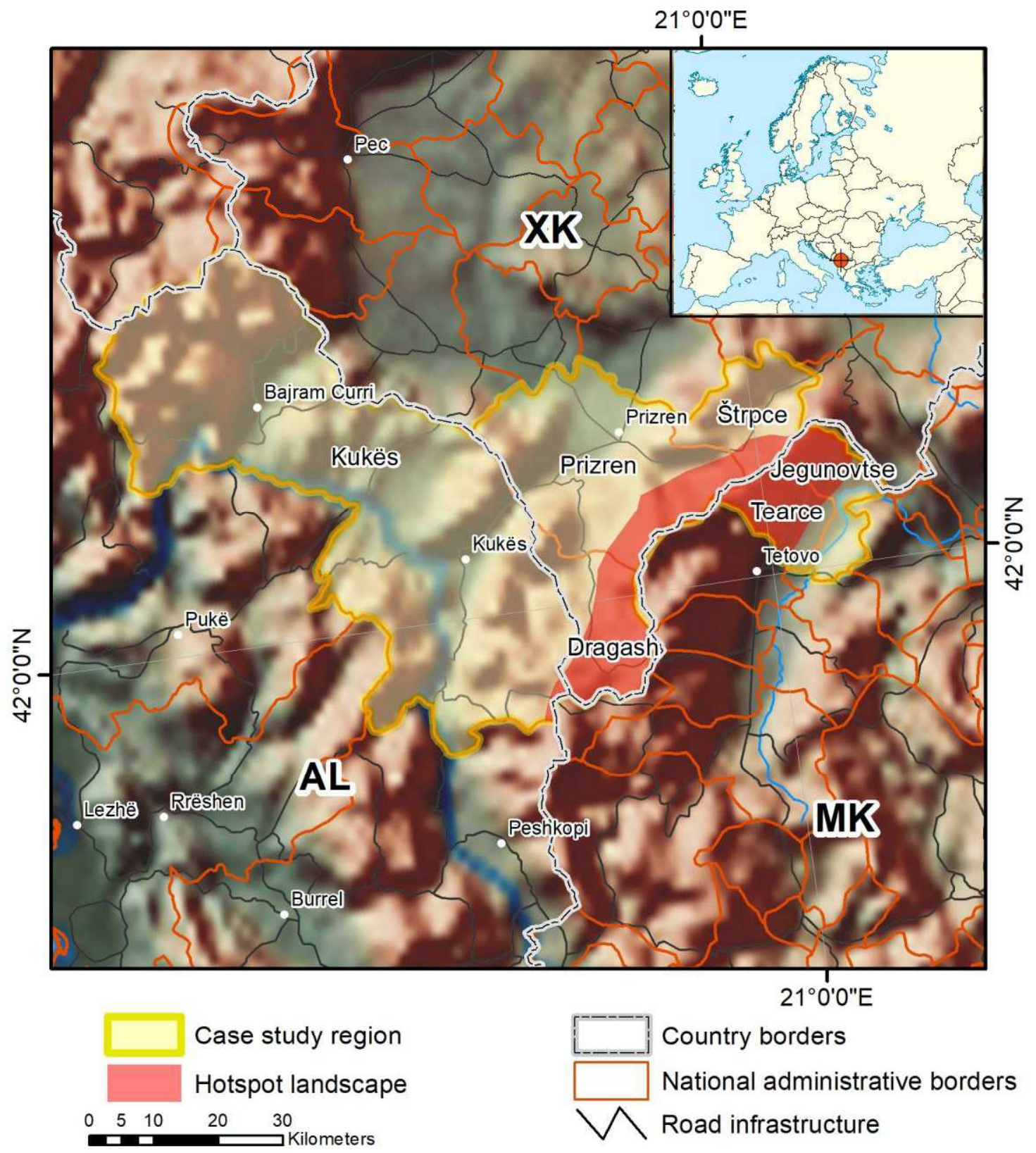

Summary of case study region and hotspot landscape

The Western Balkan (WB) countries form a social-ecological and cultural border zone with the weakest economic indicators on the European continent, and at the same time with better maintained biodiversity and rural landscapes (Milanovic and Djordjevic-Milosevics 2016). The latter represents important potential for cross-border development. The Association of European Border Regions (https://www.aebr.eu) was founded in 1971, and the EU supports the gradual integration of the (WB)

\footnotetext{
* This designation is without prejudice to positions on status, and is in line with UNSCR 1244/1999 and the ICJ Opinion on the Kosovo declaration of independence
} 
countries with the Union. In 2013 Croatia became the first of the seven countries to join, and Montenegro, Serbia, the Republic of North Macedonia and Albania are official candidates. Accession negotiations and chapters have been opened with Montenegro and Serbia, and Bosnia and Herzegovina and Kosovo are potential candidate countries. With approximately half of the population in the Western Balkans living in rural areas, rural smallholders are very important for agricultural and rural development, maintenance of cultural landscapes, employment and social safety (Milanovic and Djordjevic-Milosevics 2016). Agricultural holdings with up to 2 ha dominate (FAO 2014). However, the future of rural smallholders is uncertain due to depopulation (Möllers 2018) and lack of interest in farming among the youth. Additionally, in most WB countries policies tend to favour larger market producers, and exclude small subsistence farmers from receiving budgetary support. The reasons for this vary, ranging from an actual policy vision, to lack of funds and to implementation issues (Volk et al. 2017: 34). This is a move away from the EU practices and from alignment of policies with the Common Agricultural Policy (CAP).

The cross-border Sharra/Sharr mountain region (Шар планина, Šar planina in Macedonian and Serbian, and MoMalet e Sharrit in Albanian) (Mejzini 2007) is located in the centre of the Balkan Peninsula covering an area of 2,564 $\mathrm{km}^{2}\left(311 \mathrm{~km}^{2}\right.$ in North Macedonia, $930 \mathrm{~km}^{2}$ in Albania and 1,323 $\mathrm{km}^{2}$ in Kosovo) and with a population of around 336,400. It includes two municipalities from North Macedonia (Jegunovce and Tearce), three from Kosovo (Prizren, Shterpce/Štrpce and Dragash), and the district of Kukes from Albania. The region is an important water reservoir and is a home to more than 2,000 species of indigenous flora, and endangered carnivores (Kojen et al. 2018). The Mountains in the Balkan Peninsula are one of six centres of European ecological and biological diversity. The main economic activity in the rural settlements is livestock breeding with sheep and some cow milk production. The Sharra region is known for its cheeses, and traditional filigran, silver, blacksmith and leather crafts. Depopulation of the mountain part of the region is threatening livestock farming, which is the defining industry of the region (Kojen et al. 2018).

\section{Traditional fora}

Historic rule under the Ottoman Empire developed common values and similar traditions among the ethnicities living within the Sharra Mountains (Naumoski 2012). During the second half of the $20^{\text {th }}$ century, both North Macedonia and Kosovo were part of the socialist Yugoslavia where, often, the only organizations in villages were cooperatives, and thus represented places for social and cultural events. The ruling communist party, not the cooperative members, had the final say in the decision-making process (Zivkiv 2013). Albania's policy of isolation during that period (Bowers 1989) restricted communication across the border for the Albanians in the Sharra region. After 1991 Albania democratized its political system, but Yugoslavia broke up, which slowed down the cross-border cooperation within the region for an additional decade.

\section{New fora}

The Area-Based Development (ABD) approach implemented by the Regional Rural Development Standing Working Group in South Eastern Europe (SWG) (http://seerural.org) involves rural smallholders through a genuine bottom-up approach promoting public-private and civil sector partnerships. The approach uses an inclusive, participatory, flexible methodology that ensures integration and coherence. The nucleuses of the ABD approach are stakeholder groups comprised of rural private smallholders, as well as relevant representatives of the public and civil sectors on a local level. The stakeholder groups are informal fora for cooperation in which members meet on a regular basis to discuss and propose solutions for common cross-border issues, develop strategies for implementing the solutions, provide policy recommendations, as well as develop business ideas and 
mutual business cooperation. There is a strong focus on sustainable economic growth through promotion of the principles of sustainable use of natural resources, development of short value chains and increasing quality of local, traditional products and tourist services. The implementation of ABD approach in the Sharra region has resulted in strengthened local ownership of planning and development processes (Pavloska Gjorgjieska et al. 2019).

\section{Virtual fora}

Virtual platforms provided by SWG (e.g., https://www.facebook.com/swgsharra/, http://sharra.seerural.org/category/shg-meetings/), as well as by local NGOs and other stakeholders are used to exchange information among stakeholders of the region and aim at reaching a wider public, raising common issues, planning and informing about relevant events and activities. Virtual fora contribute to raising awareness, education, and involvement of the stakeholders in development and implementation of regional strategies and plans.

\section{Summary related to social capital framework}

The ABD approach in the Sharra region has a great impact on the development of social capital. It contributes to bonding social capital (enabling cooperation among farmers, rural operators), bridging social capital (bringing together local private operators, public authorities, social sector) and linking social capital (across the borders). To sustain the ABD approach the involved countries and their responsible Ministries for Agriculture and Rural Development should jointly consider further support of the area-based development in their national strategic and programming documents, and should plan allocation of specific funds for promotion of cooperation, capacity building and investment in crossborder business and rural development initiatives (Bogdanov et al. 2018).

\section{Literature cited}

Bogdanov, N., B. Leveska Gjorshoska, A. Palazzo, P Gjorgievski, and R. Lukesch (eds.). 2018.

Application of the LEADER approach in the Western Balkan countries - "from a local initiative to a mainstream concept in the rural areas", Standing Working Group for Regional Rural development (SWG)

Bowers, S. R. 1989. Stalinism in Albania: Domestic Affairs under Enver Hoxha, Faculty Publications and Presentations. Paper 87. http://digitalcommons.liberty.edu/gov_fac_pubs/87

FAO. 2014. Agricultural Policy and European Integration in South-eastern Europe, Food and Agriculture Organization of the United Nations.

Kojen, M., S. Djordjevic-Milosevic, P. Markovic, and F. Sekuloski. 2018. Potentials for diversification of economic activities in rural cross-border areas through short value chains development, Integral Report (unpublished), SWG RRD, 26-06-2018

Mejzini. I. 2007. The SHARR Mountains: Spatial Development based on Cross-border Cooperation. MSc thesis, Blekinge Institute of Technology. retrieved from http://www.divaportal.org/smash/get/diva2:831549/FULLTEXT01.pdf

Möllers, J. 2018. Rural Depopulation in Southeastern Europe. Agricultural Policy Forum 2018 Agricultural Policy: Determinant of the Regional Rural Development and EU Perspectives of the SEE, Jahorina, Bosnia and Herzegovina.

Naumoski, Z. 2012. Baseline Study and Strategic Plan for Development of Sharra Mountain Region, SWG RRD, http://seerural.org/wp-content/uploads/2009/05/Baseline-Study-and\%20Strategic-Planfor-development-of-Sharra-Mountain-Region-FIN.pdf

Pavloska Gjorgjieska, D., B. Ilic, B. Mohr, I. Djimrevska, and K. Kolemisevska. 2019. Area-Based Development Approach: Improving the Economic Prosperity of Rural Smallholders in the Western Balkans' Cross-Border Regions, IAMO Forum: Small Farms in Transition, 26 - 28 June 2019. 
Volk, T., Rednak, M., Erjavec, E., Zhllima, E., Gjeci, G., Bajramović, S., Vaško, Ž., Ognjenović, D., Butković, J., Kerolli-Mustafa, M., Gjokaj, E., Hoxha, B., Dimitrievski, D., Kotevska, A., Stamenkovska, I.J., Martinovic, A., Konjevic, D., Spahic, M., Bogdanov, N., Papić, R., S.

Todorović (authors); Volk, T., E. Erjavec, P. Ciaian, S. Gomez y Paloma (eds.) 2017. Monitoring of agricultural policy developments in the Western Balkan countries, European Commission, Joint Research Centre.

Zivkiv, G. 2013. Association of Farmers in the Western Balkan Countries, Policy Studies on Rural Transition No. 2013-1, FAO Regional Office for Europe and Central Asia, http://www.fao.org/3/aar592e.pdf

Milanovic, J., and S. Djordjevic-Milosevics. 2016. Biodiversity and rural livelihood in the Western Balkans. Nadodja Biblioteka Srbije, Beograd. 249 pp. 
Slovakia: Bratislava and Trnava regions, Trnava

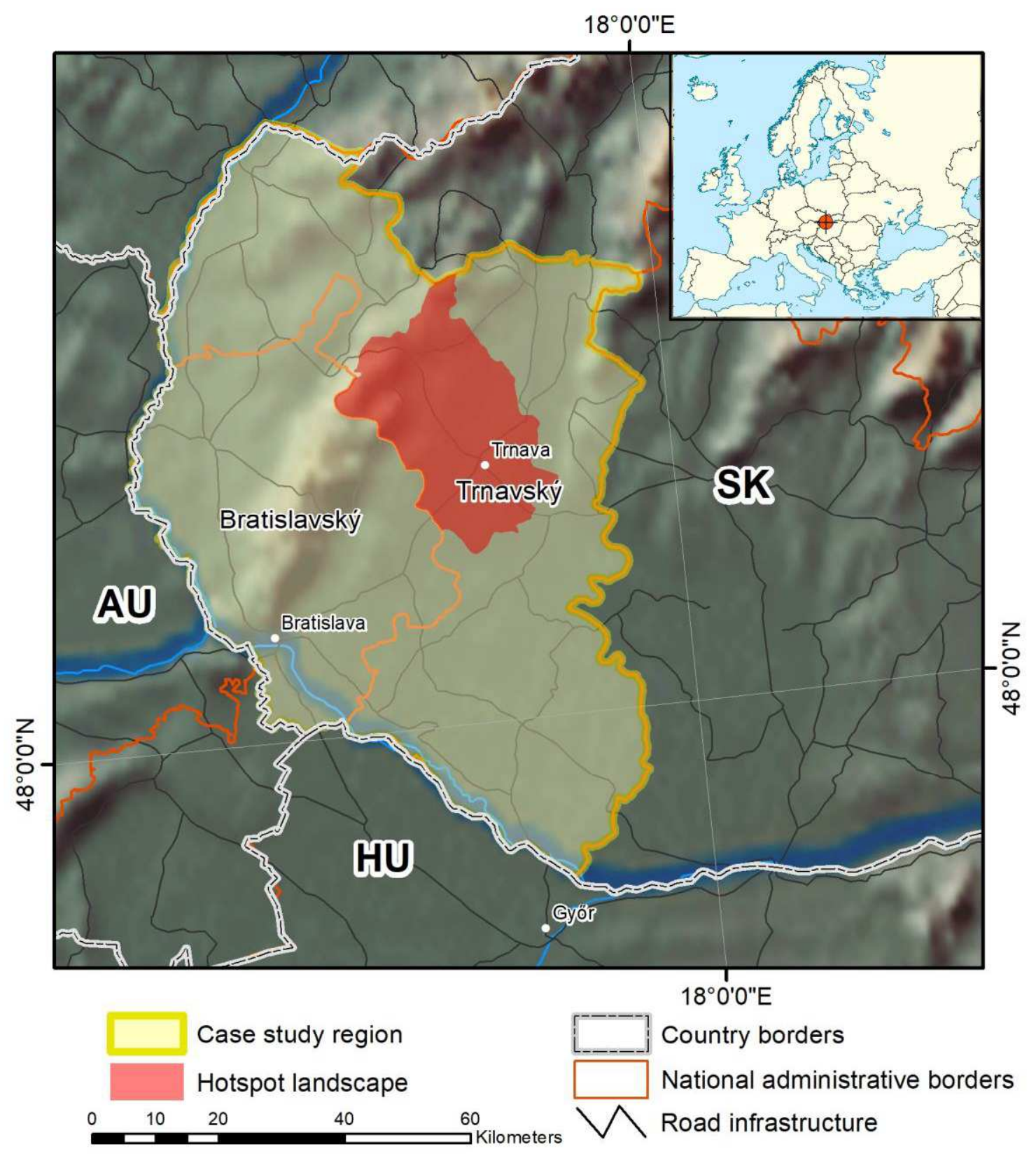

Summary of case study region and hotspot landscape

The Bratislavsky and Trnavsky regions in western Slovakia are interconnected by the Malé Karpaty hills, separating the Záhorie lowland in the west and the fertile Danubian lowland in the east. Forming an urban-rural gradient from the capital Bratislava, current dominant environmental problems include a low degree of ecological stability, few remaining natural ecosystems and the best quality soils used for development of grey infrastructure. This is enforced by investor pressures on protected areas, negative impacts associated with the development of intensive transport as well as climate change. 
The Trnava district hosts the first free royal medieval town Trnava founded in 1238. Craft manufacturing and food industries were established in the $18^{\text {th }}$ and $19^{\text {th }}$ centuries, including malting, starch and vinegar production, brewing, brickworks, distillery and bell foundry. Traditional rural landscapes on the high-quality loess brown soils were dominated by vineyards and orchards as well as production of potatoes and sugar beet (Mederly et al. 2017). During the last quarter of the $20^{\text {th }}$ and the first quarter of the $21^{\text {th }}$ centuries, intensive agriculture based on corn, maize and oilseed rape developed (Benediková 2008). Today, rural settlements undertake mono-functional intensive agriculture on productive brown soils, established and formed by the massive collectivization in 1959-1960 (Moyzeová et al., 2015). Urbanisation transformed the Trnava region from traditional forms of landscape management on the best soils into family houses and industrial plants. Industry concentrated in the city of Trnava is characterised by rapid development of automobile and electro-technic industry, which brought work to people and reduced unemployment. However, at the same time, it increased the human footprint on the region through several new environmental pressures. Implementation of EU regulation and legislation has significantly improved environment in Trnava town and villages of the district (Izakovičová et al. 2017b). Environmental laws and strategies for the protection of the landscape and its natural resources have been adopted through EU strategy for the protection of biodiversity, the European Landscape Convention, the Water Framework Directive, the Air Pollution Act, etc. Pollutants dropped subsequently by almost half and water quality has improved significantly. In the central, agriculturally utilized area, revitalization began, and ecological networks were improved. A network of NATURA protected areas has been created in the area (Izakovičová 2016, 2017b).

\section{Traditional fora}

Before collectivization, private farming dominated the region. Farmers produced goods not only for themselves but also for sale. The main traditional fora for social interaction of the rural population were associated with churches, both at regular masses and during religious holidays. Traditional trade fairs and markets where exchange trade took place were also important meeting venues. The most popular event was the Traditional Trnava Fair, which still takes place on the first Saturday of September. Pubs also played an important role. During collectivization, centralized cooperative land use management was established, and the use of the territory was decided by representatives of cooperatives. Important cultural events were held in newly built cultural centres, and annual rural festivals were organised. The importance of the churches has fallen, but the pubs have retained their dominant position as meeting places. Later, with the growth of urban industry workers, the role of rural farmers and craftsmen was reduced. Following the end of socialism in 1989, many cooperatives broke up, social life declined sharply, and lack of interest in public affairs is still spreading.

\section{New fora}

In 1976 the "Malé Karpaty" Protected Landscape Area (PLA) $\left(147 \mathrm{~km}^{2}\right)$ was established, and later several additional small protected areas with different degrees of protection. The Administration of the Malé Karpaty PLA has a dominant position in the management. After the Slovak revolution in 1989, the transition from centrally planned to market economy occurred. Co-operatives broke up and property was returned to its original owners, which encouraged the development of private business. In the early Post-Soviet period, individual and private businesses were dominant in the use of land. After Slovakia's accession to the EU in 2004, new environmental directives were adopted, and resources have been created to implement them. The administrative burden of these initiatives, as well as the nature of the land-ecological measures, stress the need for cross-sectoral cooperation. Thus, associations of municipalities providing landscape stewardship and maintenance were established, e.g., Association of Towns and Municipalities of the Malé Karpaty Region, ZMOS Jaslovské Bohunice, and Multifunctional Territory of the Trnava town. These organizations started to associate not only 
representatives of local governments, but also representatives of economic sectors and interest organizations. From an environmental point of view, the establishment of the Environmental Natural Laboratory (Izakovičová et al. 2010, 2017a), which represents a certain driving force for the development of ecotourism, can be considered a significant activity in the territory.

\section{Virtual fora}

Virtual fora are mainly used to present information by individual municipalities, as well as stakeholder discussions. Such fora are also used to present the activities of social organizations and economic entities. Various sociological surveys using virtual fora are used in decision-making processes and in municipal management. However, being especially popular with the younger generation, the use of virtual fora is limited by the age distribution and the technical skills of users.

\section{Summary related to social capital framework}

The Trnava case study illustrates the importance of social capital in municipal and regional management. In the pre-socialist period, the mayor, pastor and teacher played dominant roles in the development of the village. During socialism, representatives of the national committees and cooperatives organized social life in municipalities. In this period, centralistic decision-making dominated. The district and local national committees were the main management units in the municipalities, and were under the strong influence of the Communist party. After the end of socialistic period in 1989, the focus of decision-making has shifted to local government. The involvement of the population in decision-making takes now place on a voluntary basis. However, an increasing individualism, and apathy of the population to engage in public affairs, is negative for bonding and bridging social capitals. Additionally, there are significant pressures from lobbying groups and investors with strong linking social capital to intensify land use.

\section{Literature cited}

Benediková, D. 2008. State of Plant Genetic Resources for Food and Agriculture in Slovak Republic Second Slovak. Slovak Agriculture Research Centre RIPPP p. 39.

Izakovičová, Z. 2016. Tridsat' rokov krajinnoekologického a socioekologického výskumu v okrese

Trnava. Životné prostredie: revue pre teóriu a starostlivost' o životné prostredie. [Thirty years of landscape ecological and socioecological research in the Trnava region.] The Environment: revue for theory and care of the environment 50(1): 54-58.

Izakovičová, Z., L. Miklós, M. Moyzeová, I. Špilárová, D. Kočický, L. Halada, P. Gajdoš, J. Špulerová, Z. Baránková, D. Štefunková, P. Kenderessy, B. Šatalová, M. Dobrovodská, T. Hrnčiarová, S. David, and Z. Krnáčová. 2010. Model reprezentatívnych geoekosystémov na regionálnej úrovni - príklad okresu Trnava. [Model of representative geoecosystems on regional level - the Trnava case study]. ÚKE SAV Bratislava, Esprit, s. r. o. Banská Štiavnica, 178 p.

Izakovičová, Z., P. Bezák, P. Mederly, and J. Špulerová. 2017a. Uplatňovanie konceptu ekosystémových služieb v plánovacej a riadiacej praxi v Slovenskej republike - výsledky projektu OpenNESS na prípadovej štúdii Trnava. Životné prostredie: revue pre teóriu a starostlivost' o životné prostredie. [Implementation of the ecosystem services concept in planning and management practice in the Slovak Republic - results of the OpenNESS project in Trnava case study. ] The Environment: revue for theory and care of the environment 51(4): 198-204.

Izakovičová, Z., P. Mederly, and F. Petrovič. 2017b. Long-term land use changes driven by urbanisation and their environmental effects (example of Trnava city, Slovakia). Sustainability 9(9): 1-28.

Mederly, P., P. Bezák, Z. Izakovičová, A. Dobrucká, J. Lieskovský, and A. Halabuk. 2017. Vybrané metódy hodnotenia ekosystémových služieb - projekt OpenNess a prípadová štúdia 
Trnava. Životné prostredie revue pre teóriu a starostlivost' o životné prostredie, [Selected methods of evaluation of ecosystem services - OpenNESS project and Trnava case study. ] The Environment: revue for theory and care of the environment 51(4): 205-212.

Moyzeová, M., L. Miklós, B. Šatalová, Z. Izakovičová, J. Oszlányi, P. Kenderessy, D.

Stefunková, and Z. Krnáčová. 2015. Hodnotenie kvality životného prostredia vidieckych sídiel (na príklade vidieckych sídiel okresu Trnava) [Evaluation of the quality of the environment of rural settlements (on example of rural settlements in Trnava district)], ÚKE SAV, Bratislava, $280 \mathrm{p}$. 


\section{Portugal: Ėvora/Alentejo central region, "Sitio de Monfurado"}
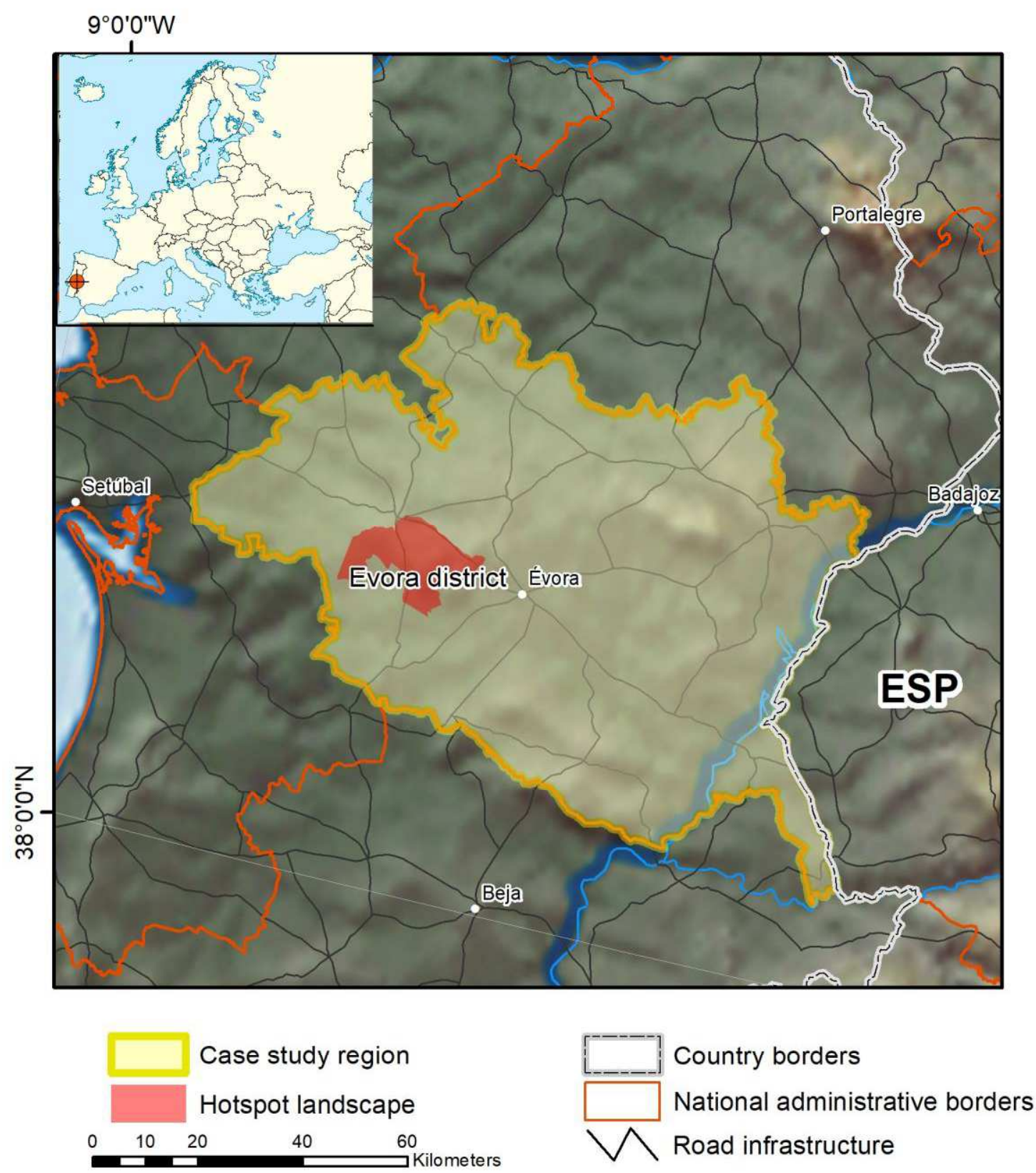

Summary of case study region and hotspot landscape

Évora/Alentejo-Central is one of four districts of the administrative region Alentejo. The capital of the district, Évora, is primarily an agricultural trade centre (Freire and Lains 2019), with tourism lately becoming economically relevant (EC RIM+2019). Prehistoric cave paintings and stone monuments lie nearby. Originally known as Ebora, the city long remained an important Roman military centre. Évora was conquered by the Moors in the $8^{\text {th }}$ century, who named it Jabura, and it remained under Moorish rule until c. 1166. Nowadays, the landscape is dominated by the Montado agroforestry system. The Montado is a human-shaped agroforestry ecosystem composed of cork and holm oak (Quercus suber and Quercus rotundifolia), grasslands and cereal croplands (Pinto-Correia et al. 2011). Threats to the 
Montado system include the rapid intensification of farming systems, the abandonment of extensive grazing, the degradation of streams due to agricultural abuse of river banks, trampling caused by intensive livestock breeding and water pollution, along with other minor threats such as interventions in watercourses (regularization, vegetation cutting, damming), afforestation with exotic tree species, forest fires and road construction (Godinho et al. 2016). These negative factor threaten the multiple values attributed to the Montado system at the regional level (Pinto-Correia et al. 2019).

The Sítio de Monfurado covers $240 \mathrm{~km}^{2}$, is part of the EU Natura $2 \mathrm{~K}$ network, and lies within the municipalities of Montemor-o-Novo and Évora. There are 149 private farms in this area with an average size of $104 \mathrm{ha} \mathrm{(http://www.hnvlink.eu/learning-areas/sitio-de-monfurado/).} \mathrm{The} \mathrm{landscape} \mathrm{is} \mathrm{an}$ agricultural mosaic dominated by the Montado system, but also including olive groves and vineyards, especially around the towns, and also semi-natural shrubland and pastures in the hilly and more remote areas. The woodland of the Montado system provides wood, cork and shade for livestock (Ferraz de Oliveira et al. 2016). There are also structurally diverse riparian wooded corridors and some temporary ponds. The Montado in the Monfurado site is generally in favourable condition of conservation (http://www.hnvlink.eu/learning-areas/sitio-de-monfurado/). It also hosts low intensity livestock production including bovines, sheep, goats and some pigs. The area has considerable natural and cultural heritage values and has hosted various EC-LIFE projects, including at least one project specific to the site

(http://ec.europa.eu/environment/life/project/Projects/index.cfm?fuseaction=search.dspPage\&n_proj_id $=2439 \&$ docType $=$ pdf). Land use in the area is thus largely multifunctional, and can be classified as $65 \%$ agriculture overlapping $72 \%$ forestry. Main crops include fallow (22\%), olive groves (16\%), fodder and temporary meadows (13\%), cereals $(7 \%)$ and arable $(7 \%)$. Branding strategies for high quality food production focus on beef (Mertolenga and Alentejo breeds), mutton (Montemor-o-Novo Lamb), Évora cheese, Alentejano pork and Alentejo honey (http://www.hnvlink.eu/learning-areas/sitiode-monfurado/). Nevertheless, few farmers are focusing on food quality and environmental targets, as evidenced by low uptake rates of EU CAP agri-environmental measures. In terms of socio-economic performance, $68 \%$ of the Monfurado area is considered by the Portuguese government as a fragile rural site, with labour income $<60 \%$ of the regional average and with a relatively large fraction of the population at high risk of abandonment in case of public fund withdrawal. Population density is low (6 inhabitants $\left./ \mathrm{km}^{2}\right)$, ageing, and those working in agriculture are few (11\%).

\section{Traditional fora}

Land was traditionally owned by very few landlords, frequently absentees living in Lisbon or Évora. For landlords, hunting for deer and boar has been frequently used for social interaction, which is frequently still the case (http://www.hnvlink.eu/learning-areas/sitio-de-monfurado/). Until few decades ago, the larger (500-3000 ha) farms frequently hosted workers' housing and also schools, a church, and bars as meeting venues mainly for men. Traditional meeting places for women were largely restricted to their homes and domestic work. Workers kept homes in the small villages, with small home gardens and orchards for own consumption. In this very socially segregated society a central worker meeting place was the "Casa do povo" (people's house) in the village. Associations for small game hunting (rabbit and partridge) were, and still are another venue for working men. A third social group of inhabitants was formed by professionals (e.g., doctor, teacher and veterinary) who also lived in the villages and held their own separate meeting places.

\section{New fora}

Today, farm workers have moved to live in the villages. Municipalities and rural neighbourhoods (freguesias) are the current providers of meeting places. Certain public entities have placed 
considerable efforts into increasing farmers' awareness of natural and cultural landscape values. An example of this is the strong engagement of farmers in the Natura $2 \mathrm{~K}$ site planning process, partly triggered by demand for visiting the Monfurado area from an urban-tourist perspective. Several ongoing and recent EU research and development projects led by the University of Évora have stimulated active involvement of different local and regional stakeholders. This has entailed the gathering of information, discussions, sharing and dissemination of knowledge and practices for the High-Nature-Value agro-silvo-pastoral Montado system.

\section{Virtual fora}

The Sítio de Monfurado has also benefited from the Tertúlias do Montado discussion, also coordinated by the University of Évora. This initiative fosters a regular and structured dialogue between researchers, land owners and managers, public administrations and the private sector towards the sustainable development of the agro-silvo-pastoral Montado system. This has included a series of active virtual communication channels that were developed using social communication tools such as WhatsApp and its own blog (tertuliasdomontado.blogspot.com). The initiative is open-ended and permits a virtual and face-to-face continuous dialogue amongst the many social actors operating in the area. Another initiative of relevance was chaired by the municipality of Montemor-o-Novo, focusing on short-chain agricultural production (http://www.cm-montemornovo.pt/pt/sitenoticias/Paginas/Projeto-Km-0-Montemorense.aspx).

\section{Summary related to social capital framework}

Current challenges for the Sítio de Monfurado landscape include that there are no notable regional products. This is reflected in the absence of a territorial trademark specifically linked to this site (http://www.hnvlink.eu/learning-areas/sitio-de-monfurado/). In addition, there is certain social resistance to shifting the character of multi-functional landscapes (Ferraz de Oliveira et al. 2016, PintoCorreia et al. 2019). Lack of investment is triggered by an ageing population of farmers, but this is partly compensated by the rise in nature tourism, and the desire for a rural lifestyle of younger urban inhabitants. Old and new stakeholder constellations do possess bonding social capital, but not interact frequently to strengthen bridging social capital. Interactions maintained through university projects and initiatives, contribute to bridging and linking social capitals.

\section{Literature cited}

EC RIM + (European Commission Regional Innovation Monitoring Plus). 2019. Alentejo Region of

Portugal. [Available at: https://ec.europa.eu/growth/tools-databases/regional-innovation-

monitor/base-profile/alentejo-region-portugal-0] 19/11/2019

Ferraz-de-Oliveira, M.I., C. Azeda, and T. Pinto-Correia. 2016, Management of Montados and Dehesas for High Nature Value: an interdisciplinary pathway. Agroforestry Systems 90 (1):1-6.

Freire, C., and P. Lains. 2019. An Agrarian History of Portugal, 1000-2000: Economic Development on the European Frontier. Historia Agraria 77:203-255.

Godinho, S., N. Guiomar, R. Machado, P. Santos, P. Sá-Sousa, J.P. Fernandes, N. Neves, and T. PintoCorreia. 2016. Assessment of environment, land management, and spatial variables on recent changes in montado land cover in southern Portugal. Agroforestry Systems 90:177.

Pinto-Correia, T., N. Ribeiro, and P. Sá-Sousa. 2011. Introducing the montado, the cork and holm oak agroforestry system of Southern Portugal. Agroforestry Systems 82(2):99-104

Pinto-Correia, T., J. Muñoz-Rojas, M. Thorsoe, and M. Noe. 2019. Governance Discourses Reflecting Tensions in a Multifunctional Land Use System in Decay; Tradition Versus Modernity in the Portuguese Montado. Sustainability 11(12): 3363 


\section{Spain: Palencia province, Palencia Model Forest}

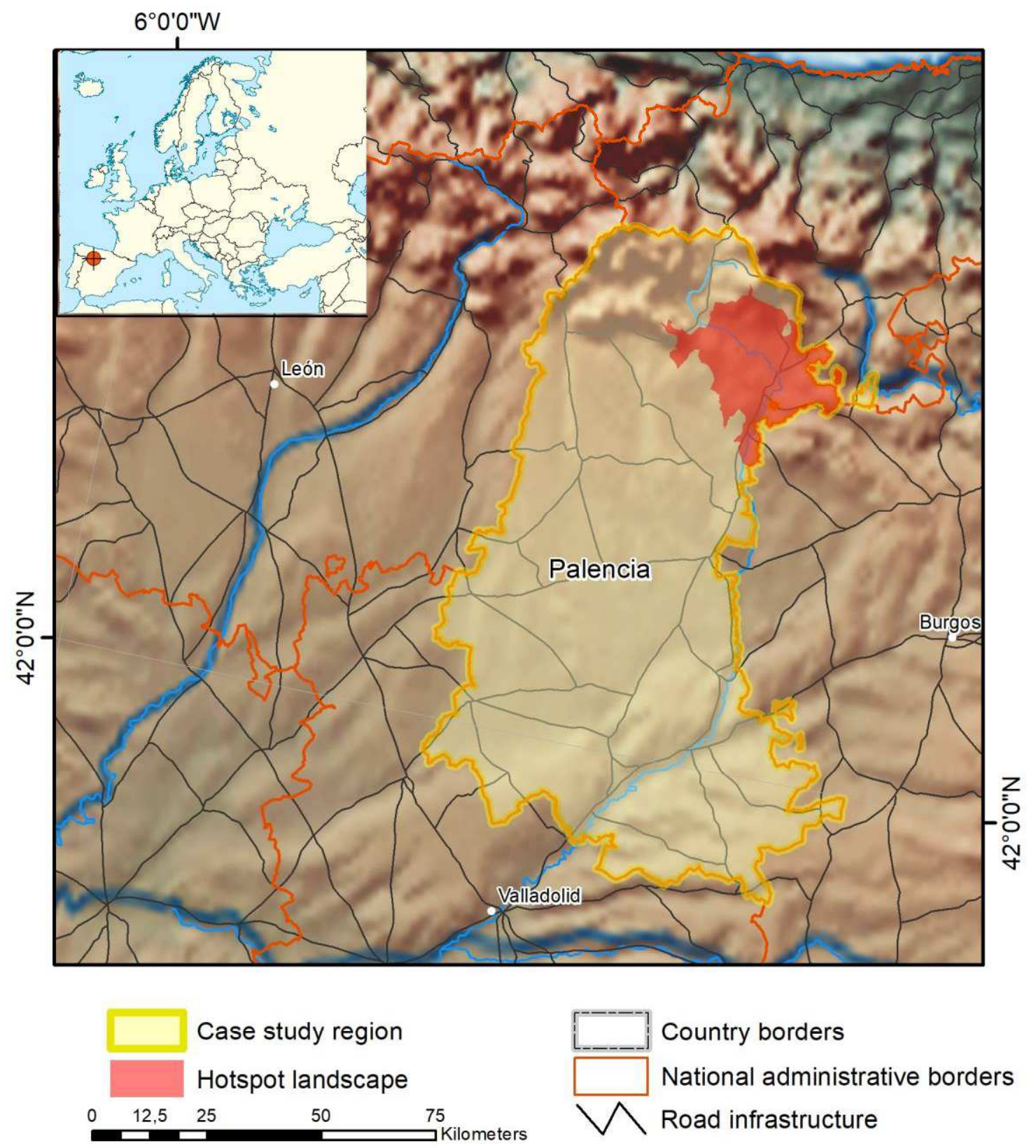

Summary of case study region and hotspot landscape

Palencia is a province in the northern part of the Castile and Leon region in Spain. Celtiberians, Romans, Visigoths, Muslims and Christians created a history of occupation and transformation of the territory, with valuable cultural, historical and artistic heritage remains in the region. During the $13^{\text {th }}$ century the first university on the Iberian Peninsula was founded in the province. Palencia ranges from a high plateau with agricultural land in the south to forests in the foothills with focal forest species (Pollo et al. 2005, Mateo-Tomás et al. 2010) of the Cantabrian Mountains in the north, which rise to the Curavacas top at 2,520 m. The dominant tree species are broadleaved (Quercus ilex and Quercus pyrenaica) and conifer (Pinus pinaster and Pinus sylvestris). 
The Palencia Model Forest initiative is made up of 92 municipalities, covering an area of $4,067 \mathrm{~km}^{2}$ and with 42,905 inhabitants distributed in a heterogeneous way. A total of $80 \%$ of the population lives in six small towns with 2,000 to 7,000 inhabitants, and the rest live in $>300$ villages. The majority of the villages have $<200$ inhabitants, most of them elderly people with limited social interactions. Demographic disequilibrium, ageing and masculinization are big issues. Until the 1970s the main activities were coal mining and agriculture, but now mines are closed with a need for landscape restoration (Alday et al. 2011), and agriculture occupies less the 12\% of the labour force. Local economy is weak and labour market is narrow, basically dependent on the third economic sector based on the local market and low qualified services. The more qualified employees live in cities and commute every day. There is also some agro-food industry in the small towns that have better road connections. Based on the richness of cultural and natural landscapes, tourism became an important economic activity in the last decades. This context is represented by 10 municipalities in the NW corner of the Palencia Model Forest initiative, of which 4 are shared with the Las Loras UNESCO Global GeoPark initiative. There are several protected areas in the territory such as the Palentina Mountain Natural Park. The pilgrim trail Camino de Santiago represents an important economic and social tourism activity

\section{Traditional fora}

The patterns of social interactions are very different depending on the specific group of people and their social and cultural practices, e.g. elderly, young, male or female. But traditional and new places have been working and still do function well as meeting points for everyone. Following the cultural Spanish traditions churches and bars are very important meeting places. There is at least one catholic historical church in almost every village, and in many of them there is more than one bar/coffee-shop. Currently, churches mostly gather a few elderly people once a week for the mass, and bars are more popular. People usually say that a village without a bar is a dead village. In the past, bars were a male meeting place. Social practices changed a lot in the last decades, but nevertheless gender still shapes spaces and times for social interaction. Elderly women still resist spending time at bars for social activities, and this pattern is stronger in smaller villages. Bars are traditional meeting places, but in many little villages the last bar closed many years ago.

\section{New fora}

Nowadays, some of those old meeting places have been renewed and opened again by immigrants or local young people with new functions and activities attracting young people. Market places and medical centres are also spaces for social interaction, mainly for women. Local open-air market activities in small villages also produce occasions for interaction and talk about common village issues. Schools, playgrounds and other children's activities spaces work as meeting places for young parents, building special networks. An association to promote a kindergarten in one of the Palencia MF's medium size villages resulted from those kinds of interactions among young parents. Novel use of natural resource values (forests, streams, several freshwater reservoirs) and historical and cultural heritage present potential for rural development. Another new meeting place is provided by the UNESCO Global Geopark "Las Loras", which was declared in 2017 after a strong bottom-up social participatory process in the territory.

\section{Virtual fora}

Virtual spaces for social interaction are related to new consumer and community life styles.

Remarkable examples are organic food consumer networks (that have face-to-face activities and mailing list interactions) and different kinds of associations, e.g., feminist association, rural tourism network, women entrepreneurs association and local trade association. All these new spaces interact in 
the virtual world of internet and social media networks. Many of them are also engaged in platforms and structures to rural development at landscape level and connected in international entities like IMFN (www.imfn.net), UNESCO Geoparks and EU LEADER.

\section{Summary related to social capital framework}

Depopulation, out-migration of women and young people to cities are the main concerns for local communities because they directly jeopardize gender relations and intergenerational support and challenge bonding social capital. Telecommunications and new internet infrastructures are still deficient in rural areas, and many villages are badly connected with the world even by cell phone. On the other hand, foreigner in-migration, tourism and local networking initiatives, like organic producer and consumer networks, are promoting quality and quantity of bridging social capital. Also rural development agencies and international landscape governance initiatives have been promoting rural and urban interactions and linkages at the local, regional and international level. Through social diversity promotion and landscape governance initiatives bridging and linking social capital are being slightly supported. Cultural, social and economic diversity are on the ground of a shyly growing rural cosmopolitanism (Woods 2018).

\section{Literature cited}

Alday, J.G., R.H., Marrs, and C. Martínez Ruiz. 2011. Vegetation succession on reclaimed coal wastes in Spain: the influence of soil and environmental factors. Applied Vegetation Science 14(1):84-94.

Mateo-Tomás, P., P.P. Olea, and I. Fombellida. 2010. Status of the Endangered Egyptian vulture Neophron percnopterus in the Cantabrian Mountains, Spain, and assessment of threats. Oryx 44(3): 434-440.

Pollo, C.J., L. Robles, J.M. Seijas, Á. García-Miranda, and R. Otero. 2005. Trends in the abundance of Cantabrian Capercaillie Tetrao urogallus cantabricus at leks on the southern slope of the Cantabrian Mountains, north-west Spain. Bird Conservation International 15(4):397-409. 


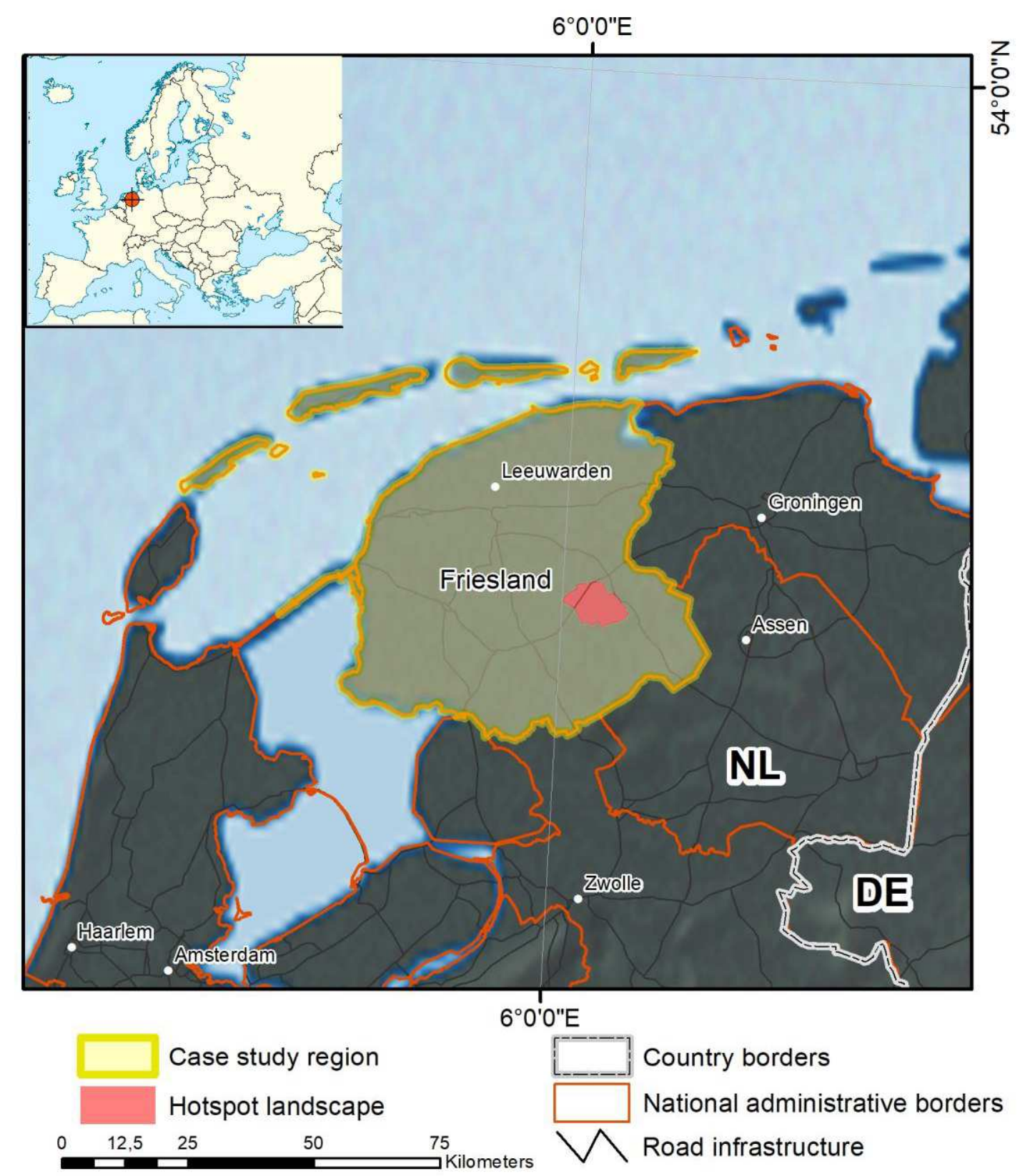

Summary of case study region and hotspot landscape

The province of Fryslân (Dutch spelling Friesland) is located in the NW part of The Netherlands. Most of Fryslân is on the mainland, but it also includes a number of West Frisian Islands. Earlier than 2000 $\mathrm{BP}$ the coastal region changed from a wooded region to a vast marsh between the higher sandy ground and the coast (Fokkens 1998). Early land use included animal husbandry based on grazing on wet meadows (Van Gijn and Waterbolk 1984), and from the 16th century grasslands expanded through drainage programs and construction of dykes (Hoeksema 2007, Van der Linden 2017). 
The park landscape with a number of privately-owned estates and country houses around the village of Beetsterzwaag (ca. 3,500 inhabitants in $74 \mathrm{~km}^{2}$ ) with many wealthy inhabitants in the municipality of Opsterland is situated in the eastern part of the Fryslân province. The former owners found their profits for example in agricultural activities and peat extraction from the $17^{\text {th }}$ century onwards. The surrounding areas were characterised by small houses were the peat workers lived in poor conditions. Beetsterzwaag can be seen as a rural area with a mix of forests, agricultural meadows and parks, while in a Pan-European context it can be seen as semi-urban. In the $19^{\text {th }}$ century the gardens around the country houses were designed with the help of famous landscape architects, and some rich families married into aristocracy (Immerseel and Verhoeff 2016). Since around 1875 rich industrialists and high-level government officials settled in Beetsterzwaag permanently, or built summer country houses. Increased accessibility through the construction of a steam tram at the turn of the $20^{\text {th }}$ century stimulated tourism in this area. In recent years new policy for tourism has been developed, and input from landowners and forest owners on land use decisions is needed. Today the former homes rich industrialists attract thousands of visitors yearly. This provides regional income, but also negative spillover effects in terms of litter, damage to paths and parking sites, disturbance of wild animals and less privacy for the owners themselves.

\section{Traditional fora}

The Beetsterzwaag park landscape was created at the beginning of the $17^{\text {th }}$ century when the first wealthy families bought small farms and created country houses. For instance, in the early 1800s one of the large landowners of Beetsterzwaag owned 141 farms and 34 houses (Immerseel and Verhoef 2016:46). Hence, the landowning families were the key units for land use decision-making. In the village the working people met during church services, in the pub or in associations for politics and sports.

\section{New fora}

In the early $20^{\text {th }}$ century, ownership of the estates to a large extent moved from private to institutional ownership by charities largely set up by legacies of aristocratic families. The Cornelia society, which funded activities supporting recovery from illness, is one example. This institutional ownership prevented the fragmentation of ownership through dividing land among heirs. Nevertheless, landownership remains complex, and is seen as a great challenge to manage this landscape and consider the many different driving forces. Though the present estate owners remain as key units, in recent years the key forum is the Association of Landowners (Opsterlandse Groene Parels (OGP)). This consists of two noble families (van Harinxma thoe Slooten and Van der Sluis); a major Dutch insurance company (a.s.r. verzekeringen); two nature conservation organisations (It Fryske Gea, the Frisian regional organisation for landscape protection with its country estate headquarters (30.000 plus members) in Beetsterzwaag, and Staatsbosbeheer, the largest Dutch semi-government nature organisation); the Golf \& Country club Lauswolt; and two societies coming from historic noble gentry (de Stichting Van Teyens Fundatie and the Cornelia-Stichting). In the recent decade the Association of Landowners took several initiatives to develop joint visions and actions to maintain the landscape qualities by involving land owners across the whole area (Berkhof and Fennema 2012, Strootman and Fennema 2014). New economic models to finance the costly park landscape management are needed (Sijtsma et al. 2017). However, individual stakeholders seem to focus more on the differences among them than on their interconnections. The local authorities are looking for new ways to develop collaboration with more interaction between them and the private owners in the field of for example tourism and spatial planning. They operate next to each other but not in cooperation with each other. 
A very interesting new phenomenon is a stakeholder movement that began in 2017, which was fuelled by the decentralisation in 2011 of large parts of national nature policy (Nature Pact) to the 12 Dutch provinces. This led to gradual budget cuts in Fryslân. A number of nature conservative organisations such as Natuurmonumenten, Staatsbosbeheer, It Fryske Gea as well as Friesch Grondbezit and the Bosgroep Noord-Oost Nederland did not accept these cuts, and started negotiations with the provincial authorities to find alternatives. This evolved in 2018 to the founding of a stakeholder movement, 'Natuer mei de Mienskip' (Nature and Community)), which since 2019 is the representative of private and public owners of nature areas, forests and agricultural property. This is a new step towards acquiring, designing and managing the Frisian nature.

\section{Virtual fora}

Virtual cooperation is weakly developed. In a recent project some initiatives were taken to set up an online community of Beetsterzwaag fans, but until now this has been unsuccessful. However, individual organisations often have well-developed websites to interact with their constituents. See for example www.natuurmonumenten.nl; www.itfryskegea.nl; www.staatsbosbeheer.nl, www.beetsterzwaag.nl.

\section{Summary related to social capital framework}

This case study landscape illustrates the role of bonding social capital among similar land-owning units but with widely different individual strategies. In contrast, bridging social capital in terms of trusting relations between the land owners, the municipalities and local inhabitants, and linking social capital connecting adjacent local governments and the province are still weak and need to be reinforced.

\section{Literature cited}

Alen, T. van, and J. Thielemans. 2007. Het gevarieerde cultuurhistorische landschap, gebiedsvisie cultuurhistorie Beetsterzwaag e.o. ('The varied cultural historical landscape, a vision on the area of Beetsterzwaag and surroundings'). Velp.

Balemans, C. 2008. Toekomstplan "Groene Parels aan een Blauw Snoer", bijzondere waarden rondom Beetsterzwaag. (Future plan 'Green pearls on a Blue string', special values around Beetsterzwaag') Witharen.

Berkhof, A., and A. Fennema. 2012. Parels in een groen frame, ontwikkelingsvisie parklandschap Beetsterzwaag \& Olterterp. ('Pearls in a green frame, vision on the development of park landscape Beetsterzwaag and Olterterp')

Fokkens, H. 1998. Drowned landscape: the occupation of the western part of the Frisian-Drentian Plateau, 4400 BC-AD 500. Uitgeverij Van Gorcum.

Gemeente Opsterland (Municipality Opsterland). 2015. Omgevingsvisie 2015- 2030. ('Spatial environmental vision document 2015-2030') Beetsterzwaag,

Hoeksema, R.J. 2007. Three stages in the history of land reclamation in the Netherlands. Irrigation and Drainage: The journal of the International Commission on Irrigation and Drainage, 56(S1), pp.S113S126.

Immerseel R., and P. Verhoeff. 2016. Statig Beetsterzwaag - Parklandschap rond een Fries dorp. ('High-class Beetsterzwaag - Park landscape around a Frisian village') Stichting Matrijs, Utrecht

Oldenburger, J., and J. van den Briel. 2016. Beheerkosten recreatief medegebruik landgoederenzone Beetsterzwaag. Wageningen, ('Maintenance costs recreational use of the country house area Beetsterzwaag')

Sijtsma, F.J., M.N. Daams, and L. Hans. 2017. Landgoederengordel Beetsterzwaag, kosten en baten in beeld. ('Country houses Beetsterzwaag, A view on cost and benefits'). Groningen, University of Groningen. 
Strootman, B., and A. Fennema. 2014. "Landgoedmodel Beetsterzwaag” samenwerken voor een nieuwe landschapseconomie ('Country house model Beetsterzwaag' cooperation for a new landscape economy.')

Van der Linden, H. 2017. History of the reclamation of the Western Fenlands and of the organizations to keep them drained. Land Drainage and Irrigation.

Van Gijn, A.L., and H.T. Waterbolk. 1984. The colonization of the salt marshes of Friesland and Groningen: the possibility of a transhumant prelude. Palaeohistoria 26:101-122. 


\section{Scotland: Lochaber region, Sunart}

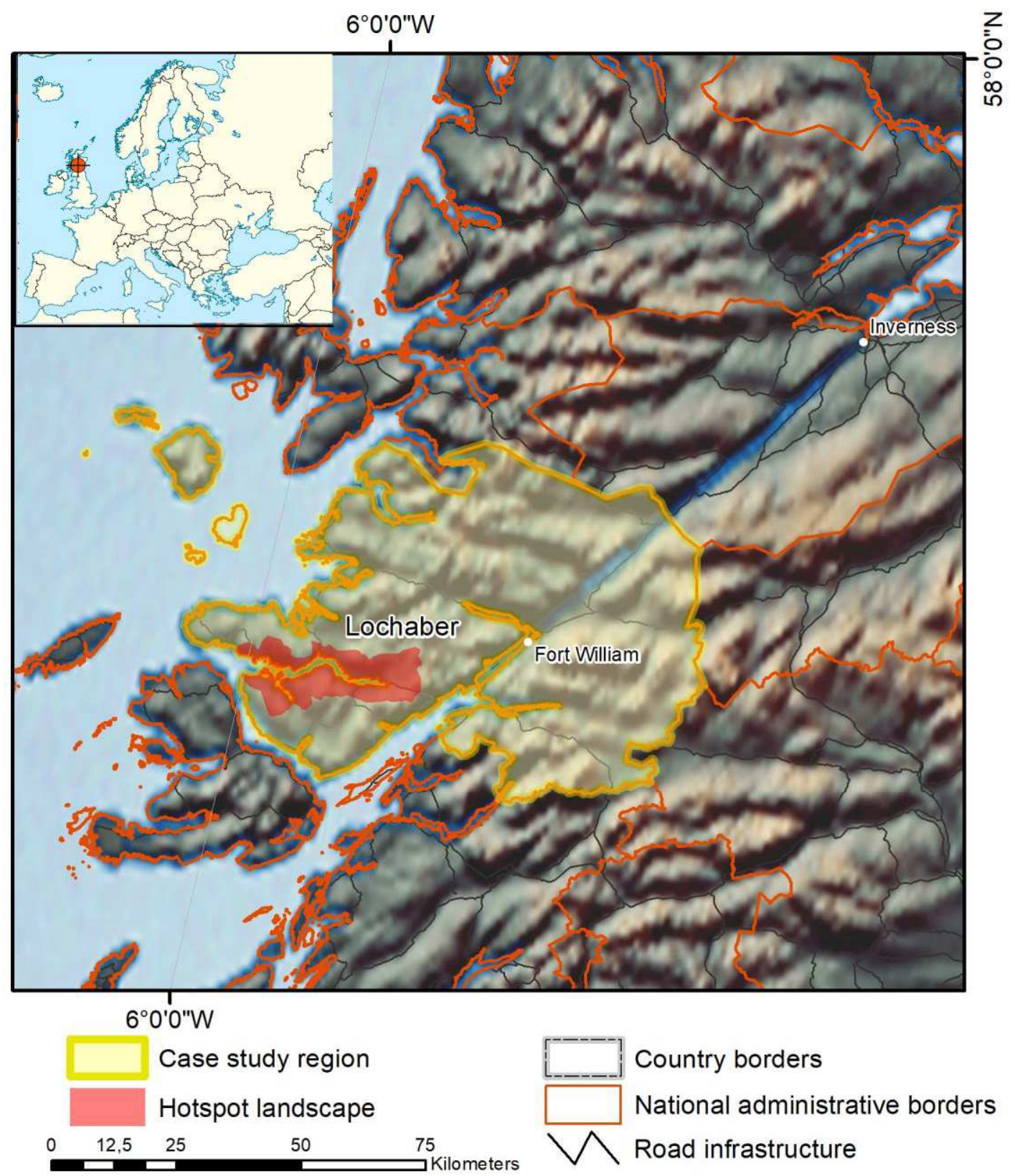

\section{Summary of case study region and hotspot landscape}

Lochaber is a remote region in the Western Highlands of Scotland, with Fort William as its main town (population 10,500). The region is under pressure from depopulation and limited employment opportunities, and consequentially has an aging population. Administratively it is part of the geographically very large Highland Council, while specific land management and conservation responsibilities are carried out through national government agencies ${ }^{1}$. We define Lochaber as the

\footnotetext{
${ }^{1}$ Scottish Natural Heritage (SNH), Scottish Environment Protection Agency (SEPA), Forestry and Land Scotland (FLS) and Scottish Forestry (SF)
} 
former Forest District covering an area of approximately $5,000 \mathrm{~km}^{2}$. Lochaber is a mountainous and coastal region, with land covers dominated by grassland (44\%), heathland (20\%), montane habitats (14\%) and woodland (13\%) (Forestry Commission 2013). The dominant woodland type is conifer (56\%), mainly Sitka Spruce (Picea sitchensis (Bong.) Carr) plantations that produce timber for the forestry sector, including a large sawmill in Fort William (Thomas et al. 2019). There are also remnants of native pinewoods (Pinus sylvestris) and important areas of Atlantic oakwoods (predominantly Quercus petrea (Matt) Liebl, with birch (Betula spp.), alder (Alnus glutinosa) and occasionally $Q$. robur $L$.). Open habitats support sheep grazing and sport hunting interests, but are generally considered ecologically degraded (Hobbs 2009). The region is a popular tourist destination for outdoor and nature enthusiasts and includes Ben Nevis, and the UK's highest mountain (1345m). In Scotland, land ownership is concentrated in private estates. This originates from $18^{\text {th }}$ Century enclosures of common lands to make them private property, and $19^{\text {th }}$ Century clearances of tenant farmers to make land more profitable to the landlord. There are also large publicly owned production-focused forests, and various nature reserves, which are mainly owned and managed by environmental NGOs. In recent decades Scottish Government has supported community buy-outs, resulting in various community woodlands and several community owned estates (most notably Knoydart and the Ilse of Eigg). There is a strong government policy to increase woodland cover, particularly to sequester carbon and to stimulate commercial wood production (Scottish Government 2019). However, despite consensus about potential benefits of increased woodland cover, there are competing visions of woodland expansion and the associated benefits (Burton et al. 2019).

Loch Sunart is a fjord located in the western part of Lochaber, the surrounding areas of which contain one of the most important concentrations of Atlantic oakwoods in Europe. These cover 12\% and conifers 19\% of the area (Quelch 2005a). The mild wet climate is beneficial for a rich assemblage of vascular plants, mosses, lichens and fungi. Much of the woodland was coppiced, thus forming a biocultural legacy (Quelch 2005b), now designated a Special Area of Conservation. Expansion of the native Sunart woodland is a long-term ambition (Peterken and Worrell 2001, Worrell and Long 2010), which requires deer fencing to protect trees from damage (Ratcliffe and Staines 2003). Forest restoration would improve connectivity with adjacent native pinewoods in Ardgour and at Glenfinnan (Moseley et al. 2006).

\section{Traditional fora}

There are few traditional fora for land management in rural Scotland, mainly because land management is decided individually within the vast privately-owned estates. Each estate has its own independent approach to land management, often balancing field sports (deer stalking and grouse shooting) and commercial forestry when there are suitable grants available. There are established trade-bodies or interest groups representing land managers, e.g., Scottish Land and Estates, the National Farmers Union for Scotland, and the Crofters Association for Small Holders. These organisations facilitate knowledge exchange and lobby government. Common grazing land is managed by grazing committees, which are registered with the Crofting Committee and comprising of elected crofters (small holders). The government agency "Forest and Land Scotland" manages the publicly owned National Forest Estate, and consults stakeholder groups when updating its land management plans.

\section{New fora}

There has been an increased realisation of the need to collaborate across organisations, at a landscape scale, and increasingly also with local communities. Examples include Heritage Lottery and EU funded Life projects, which bring together different government agencies, NGOs and community groups. The Sunart Oakwood Initiative was an internationally recognised exemplar that combined funding from 
Life, and various other sources to encourage good management and stewardship of the Atlantic oak woodlands around Loch Sunart (Quelch 2005a). As part of the initiative, private owners formed the North Sunart Woodland Group (NSWG), which was established to encourage a common approach to maintaining and enhancing the native woodlands, including reducing deer browsing and removing invasive species. However, it has proven difficult to keep this collaboration going since the project ended as government agencies have had fewer resources, including time, to support collaboration as before. Community buy-outs are providing opportunities for more recent collaborations between local communities, and sometimes NGOs, to collectively manage large areas. One example is the Knoydart Forest Trust, which manages woodland for the community landowner, and other landowners. (http://www.knoydartforesttrust.org/) and the Loch Arkaig Pine Forest, a Caledonian pinewood purchased from Forestry and Land Scotland in 2016 by the Arkaig Community Trust and an NGO (http://www.arkaigforest.org/). Additionally, following increased awareness of challenges to manage deer populations, which cross estate boundaries, voluntary deer management groups (DMGs) were established in the 1990s. These bring together neighbouring estates to sustainably manage deer populations and deliver on a number of 'public interest' benefits across estate boundaries. There is substantial variability in how these groups work, and their performance is evaluated by the Scottish Natural Heritage, the government agency responsible for Scottish habitats and landscapes (Scottish Natural Heritage 2011). The government agency "Scottish Forestry" encourages landscape-scale collaborative projects between multiple landowners. The Climate KIC project Forland Restoration is currently supporting stakeholder including NSWG to identify common ground for collaborative landscape management.

\section{Virtual fora}

There are only a few sporadic examples of virtual fora being used to support land stewardship in the region. For instance, the Sunart Community Company a charity based in Strontian, which supports local community development, has a website and Facebook page (Sunart Community Company 2019). Via social media they supply progress feed on their activities, including actions towards the community buy out of a local forest area. In addition, the deer management groups use a common website to detail

their plans and maps and other supplementary information on their management efforts (Association of Deer Management Groups 2018). While many community groups and the organisations involved in land management have a web presence and engage with social media, virtual fora still remain an underutilised opportunity to further structure collaborative lands management in the region more holistically. This could in part be explained by the poor broadband and mobile internet service in the area.

\section{Summary related to social capital framework}

The Lochaber region is under pressure from depopulation, limited employment opportunities and consequentially an aging population. Although unemployment is not high, jobs are poorly paid and many people need to have multiple jobs. Government cuts following the 2008 financial crash has meant that government agencies have limited time and resources for collaboration with other partners and local communities. Community land ownership and management models are emerging, but substantial social capital is required for communities to organise and initiate these partnerships. A case study by Lee et al. (2005) including SW Scotland indicated that networks of crofters can be a significant factor in how other development processes are played out.

\section{Literature cited}

Lee, J., A. Árnason, A. Nightingale, and M. Shucksmith. 2005. Networking: social capital and identities in European rural development. Sociologia Ruralis 45(4):269-283. 
Association of Deer Management Groups. 2018. http://www.deer-management.co.uk/dmgs/deermanagement-groups/deer-management-group-map/ Visited 2019-12-09.

Burton V., M.J. Metzger, C. Brown, and D. Moseley. 2019. Green Gold to Wild Woodlands; understanding stakeholder visions for woodland expansion in Scotland. Landscape Ecology 34: 1693-1713.

Caledonian Partnership. 2003. Restoring Natura Forest Habitats. Highland Birchwoods, Munlochy

Cundill, Peter R., W. N. Austin, and S. E. Davies. 2006. Modern pollen from the catchment and surficial sediments of a Scottish sea loch (fjord). Grana 45(3):230-238.

Forestry Commission Scotland. 2013. Forest Design Plan Brief. Lochaber Forest District FDP Unit: Sunart.

Forestry Commission. 2013. NFI Woodland map 2011: Lochaber Forest District report. Forestry Commission, Edinburgh.

Hobbs, R. 2009. Woodland restoration in Scotland: ecology, history, culture, economics, politics and change. Journal of Environmental Management 90: 2857-2865.

Moseley, D. G., D. Ray, and J. Bryce. 2006. Forest Habitat Network for the Atlantic oakwoods in Highland Region, Scotland. Botanical Journal of Scotland 57(1\&2): 197-209.

Peterken, G. F., and R. Worrell. 2001. Conservation management of the Sunart oak woodland SAC and the potential for supporting rural development. A report by SNH and Highland Birchwoods for the Caledonian Partnership.

Quelch, P.R. 2005a. Sunart oakwoods: a guide to their sustainable management, Highland Birchwoods, Munlochy.

Quelch, P.R. 2005b. Structure and utilisation of the early oakwoods. Botanical Journal of Scotland 57(1-2):99-105.

Ratcliffe, P., and B. Staines. 2003. Deer management requirements for the delivery of Natura 2000 objectives in Atlantic oakwoods. In: Restoring Natura Forest Habitats, p. 35-38.

Scottish Government. 2019. Scotland's Forestry Strategy 2019-2029; https://www.gov.scot/publications/scotlands-forestry-strategy-20192029/ Accessed 03.12.2019

Scottish Natural Heritage. 2011. Code of Practice on Deer Management; https://www.nature.scot/codepractice-deer-management Accessed 03.12.2019

Sunart Community Company. 2019. https://sunartcommunitycompany.co.uk/ Accessed 03.12.2019

Thomas H.J.D., J.S. Paterson, M.J. Metzger, and L. Sing. 2019. An evaluation of Scottish woodland grant schemes using site suitability modelling. Land Use Policy 80: 309-317.

Worrell, R., and D. Long 2010. Management of woodland plants in Atlantic broadleaved forests. Plantlife Scotland, Stirling. 51 pp. 